\title{
Resilience and the population history of the Kuril Islands, Northwest Pacific: A study in complex human ecodynamics
}

\author{
Ben Fitzhugh $^{1^{\star}}$, Erik Gjesfjeld ${ }^{2}$, William Brown ${ }^{1}$, Mark J. Hudson $^{3}$, Jennie D. Shaw ${ }^{4}$ \\ 1Department of Anthropology, University of Washington, Seattle \\ 2Institute for Society and Genetics, University of California, Los Angeles \\ ${ }_{3}$ Research Institute for Sustainable Environments and Cultures, Nishikyushu University, Japan \\ 4Salix Archaeological Services, LLC. Seattle
}

*To whom correspondence should be addressed; E-mail: fitzhugh@uw.edu, Mailing Address: Dept. of Anthropology, Box 353100, Seattle, WA 98195-3100, USA

\begin{abstract}
Living in remote places can strain the adaptive capacities of human settlers. It can also protect communities from external social, political and economic forces. In this paper, we present an archaeological population history of the Kuril Islands. This string of small volcanic islands on the margins of the Northwest Pacific was occupied by maritime hunting, fishing and gathering communities from the mid-Holocene to recent centuries. We bring together (1) 380 new and previously published archaeological radiocarbon dates, (2) a new paleodemographic model based on a radiocarbontimestamped temporal frequency distribution of archaeological deposits, (3) recently published paleoclimate trends, and (4) recently published archaeological proxy evidence for changes in the extent of social networks. We demonstrate that, over the last two millennia, inhabitants of the Kuril Islands underwent dramatic demographic fluctuations. Explanations of these fluctuations are considered in the context of environmental hazards, social networks and the emergence of an East Asian "World System", elucidating the tension between local and external adaptive strategies to social and ecological uncertainty. Results suggest that population resilience to local climate and environmental variability was achieved by virtue of social networks that maintained non-local support in times of crisis. Conversely, the expansion of the East Asian political economy into neighboring regions of the southern margin of the Kuril Islands perhaps in conjunction with exposure to epidemic diseases appears to have undermined the adaptive strategies, resulting in an increase in the vulnerability of Kuril populations to environmental fluctuations.
\end{abstract}

\section{Keyword}

Kuril Islands, Archaeology, Social Networks, Resilience, Paleodemography, Climate Change 


\section{Introduction}

As humans we live in a world connected, in which interactions link us to others and to the environment in complex socio-ecological systems. With a case study from island Northeast Asia, this paper examines the interweaving of social and ecological systems and their operation at different spatial and temporal scales. We focus on an archaeological case of long-term persistence punctuated by episodes of population decline. The case is set in the Kuril Islands, a remote chain of volcanic islands in the Northwest Pacific. We provide a model that emphasizes the role of interacting social networks to understand population expansion and contraction in this chain of islands throughout the first and second millennia C.E. The study has implications for the sustainability of human occupation in insular environments and for understanding the benefits as well as vulnerabilities of more or less connected communities and the challenges of mitigating unpredictability in an increasingly complex and interconnected world.

\section{Biogeography of the Kuril Islands}

Stretching from Hokkaido to the Kamchatka peninsula, the Kuril archipelago contains approximately 32 islands ranging from $5 \mathrm{~km}^{2}$ to $3200 \mathrm{~km}^{2}$ with many smaller rocky islets and outcrops (see Fig.1). Larger landmasses and a paleogeographic history of connection to temperate ecosystems in Hokkaido in periods of lower sea levels have given the southern islands higher biological diversity than the central and northern islands of the chain (Pietch et al., 2003). This includes a broad range of trees and shrubs (Anderson et al., 2008), terrestrial mammals (Hoekstra and Fagan, 1998), insects, mollusks and fish (Pietsch et al., 2001; 2003). The remote islands of the Kuril archipelago ("South-Central" and "North-Central" on Fig. 1) are geographically separated from the southern islands by the Bussol Strait, the largest open water strait in the island chain. The Bussol strait represents a significant geographic and climatic barrier to the migration of species from the southern islands to the more remote islands (Pietsch et al. 2003). While smaller and ecologically less diverse, the central and northern islands currently contain high abundances of birds and marine mammal populations, including Steller sea lions (Burkanov and Laughlin, 2005), harbor seals and sea otters.

Weather and climate are among the most significant challenges to life in the Kurils (Fitzhugh, 2012). The weather is strongly influenced by the maritime geography, proximity to strong ocean currents and broad North Pacific atmospheric dynamics (Rodionov et al., 2007). During winter months, the interaction between the Siberian High and Aleutian Low pressure systems forces cold air from the Asian continent over the Kurils producing frequent snowstorms (138 days per year on average) and stable snow cover from November until May (Ganzei et al., 2010; Leonov, 1990; Razjigaeva et al., 2008). During the summer, weather conditions are cool and moist with extensive fog cover (Razjigaeva et al., 2008). The interaction of the cold Oyashio current carrying water from the Bering Sea, the North Pacific and the warm Soya current carrying water 
from the Sea of Japan make the Kuril Islands one of foggiest places on earth, averaging nearly 215 fog-days per year on some islands (Bulgakov, 1996; Razjigaeva et al., 2011; Tokinaga and Xie, 2009). While more pronounced in winter, large and violent storms are also common in summer bringing heavy precipitation, strong winds and storm surges (Bulgakov, 1996).

[Insert Figure 1: Kuril Map]

\section{Cultural Occupation of the Kuril Islands}

The Kuril Islands have been occupied periodically since at least the mid-Holocenesome islands earlier-and archaeologists have studied the culture history of the region for over 100 years (Fitzhugh et al., 2002; Kuzmin et al., 1998, 2012; Ohyi, 1975; Shubin, 1977, 1991; Stashenko and Gladyshev, 1977; Torii, 1919; Vasilevsky and Shubina, 2006; Yamada, 1999; Yamaura, 1998; Yanshina et al., 2009). Aside from the most recent Russian and Japanese settlement of the Kuril Islands, all cultural occupations were based on hunting and gathering of marine mammals, fish, birds, eggs and to a lesser degree shellfish (Fitzhugh et al., 2004). Seaweed, leafy greens, roots, and berries would have also been important despite their poor archaeological preservation (Krashenninikov, 1972). This diet is common to traditional hunter-gatherer cultures around the North Pacific Rim (W. Fitzhugh and Crowell, 1989).

\subsection{Jomon and Epi-Jomon}

Archaeologists have reported possible Palaeolithic remains from Kunashir, Iturup and Shumshu islands (Nomura and Sugiura, 1995; Tezuka, 2011, p. 170), but according to Kuzmin et al. (2012, p. 239) no Paleolithic "artifacts from undisturbed contexts have yet been recorded". The earliest confirmed occupation of the Kurils is found on Iturup Island and dates between 7500-8000 cal BP (Yankito 1 and 2: Yanshina and Kuzmin 2010). This occupation is culturally associated with the late Initial/Early Jomon phase of Hokkaido (Yanshina and Kuzmin, 2010). Available evidence indicates that subsequent Early and Middle Jomon occupation was limited to the southernmost islands close to eastern Hokkaido. The sparseness of archaeological materials from those early, southern occupations suggests low populations densities. Because these islands have higher terrestrial mammal abundance and diversity compared to the islands farther north, we suspect that the earliest Jomon inhabitants maintained a more terrestrial orientation compared to later occupants who expanded into the central and northern islands by $3500 \mathrm{cal} \mathrm{BP}$ (below). The first prolonged occupation of islands northeast of the Bussol Strait occurred during the Late/Final Jomon period and persisted through the Epi-Jomon phase. The Epi-Jomon was an extension of the Jomon hunter-gatherer culture found in northern Honshu, Hokkaido and the Kurils at a time of expanding rice agriculture and iron usage in the Japanese mainland. Despite its name, the Epi-Jomon in northern Honshu and Hokkaido developed significant differences in subsistence and settlement patterns compared to the preceding Jomon period. In Hokkaido and the Kurils, coastal Epi-Jomon settlements intensified marine adaptations with improved harpoon technologies (H. Okada, 1998, pp. 336). The increased pursuit of sea mammals has been connected to the movement of Epi-Jomon culture into the 
Kuril Islands (W. Fitzhugh and Dubreil, 1999), though we now know that central Kuril settlement started earlier (in the Late/Final Jomon phase), as the dates in this paper demonstrate. Indeed, from the limited evidence so far available, we see very few differences so far between Late Jomon and Epi-Jomon occupations in the Kurils. The earliest access to iron and rice dates to the Epi-Jomon period (Yamaura and Ushiro, 1999, p. 43) and by the mid first millennium (late Epi-Jomon in transition to Satsumon), swords, armor, and other rare goods were obtained by Hokkaido groups, suggesting an expanding interaction sphere reaching as far south as the Kofun state, based in the Osaka/Kyoto region (Yamaura and Ushiro, 1999, p. 43).

\subsection{Okhotsk and Satsumon}

Okhotsk people moved into the Kurils from Eastern Hokkaido about 1300 cal BP persisting for 500-600 years. In northern and eastern Hokkaido and the Kurils, the Okhotsk Culture is understood as the intrusion of aunique population or populations from the western Sea of Okhotsk who were largely distinct from people of the preceding Epi-Jomon Culture and their Satsumon descendants (Amano, 1979; Amano and Vasilevsky, 2002; Vasilevsky, 2005; Ono and Amano, 2007; Sato, et al. 2007, 2009; Deryugin, 2008). The Okhotsk specialized in marine mammal hunting with the use of complex harpoon technologies like those of contemporaneous cultures of the northern Bering Sea region (Chard, 1961; Befu and Chard, 1964). Okhotsk communities were often extensive with numerous, large houses, and in some areas (but apparently not the remote Kurils), Okhotsk communities built fortified settlements and engaged in intracultural warfare (Shubina, 1999; Samarin and Shubina, 2007). While Okhotsk groups eventually settled around the Sea of Okhotsk coast from Sakhalin to the Kurils, the Satsumon descendants of the Epi-Jomon in southern Hokkaido expanded millet cultivation and increased trade with northern Honshu. As a result, during the mid to late first millennium C.E., Hokkaido became divided into two spheres of influence: The Okhotsk shared cultural, ethnic and economic connections to the northwest, while the Satsumon were drawn increasingly, if indirectly, into the sphere of mainland Japan and its expanding political economy.

\subsection{Tobinitai and Ainu}

The Ainu emerged in the centuries after 1000 C.E. by a process now believed to involve assimilation of eastern Okhotsk populations into the Jomon-descendent Satsumon communities of southern and eastern Hokkaido (Hudson, 1999, 2004). A transitional culture, referred to as Tobinitai, developed in this region bringing together elements of Okhotsk and Satsumon traditions (Onishi, 2003; Vasilevsky and Shubina, 2006). In Hokkaido and southern Sakhalin, Ainu communities abandoned semisubterranean pit dwellings for rectangular, above-ground structures, gave up pottery for ironware and made more of their tools from metal rather than stone. In the Kuril Islands and southern Kamchatka, Ainu groups retained the use of pit dwellings and pottery in a form emulating iron cookware used by Ainu elsewhere (Torii, 1919; Dikov, 2004;

Takase, 2013), while using a greater range of iron implements than their predecessors. Ainu patterns of life and culture are more clearly influenced by contact with outside traders than were any prior groups in Hokkaido or the Kurils. 
The Ainu and their ancestors had been mentioned in Japanese documents since the 8th century, but the first Russian records appear only in the early 18th century (from initial contact in the Northern Kurils) (Krasheninnikov, 1972). Ethnohistoric accounts describe a hunting, fishing and gathering culture with deep spiritual connection to the natural world (Bachelor, 1901; Etter, 1949). North of Urup Island, the Ainu in the Kurils are described as having a unique subculture with distinct dialect and practices (Snow 1897; Krasheninnikov, 1972; W. Fitzhugh 1999; Tamura 1999). From the 18th century, the Kuril Ainu were increasingly impacted by the expansion of Japanese and Russian competition, settlement and control of the Kuril chain (Walker, 2001; Tezuka, 2009). By the time of initial contact with Russians, Kuril Ainu were living in the northern and central archipelago and had influenced the material culture of the Pacific coast of Kamchatka from the southern tip at Cape Lopatka to Nalychevo Lake, $50 \mathrm{~km}$ north of Avacha Bay (Dikov, 2004). Dikov (2004) attributes the material culture from Ainu sites in this region to the later Ainu period, based on use of interior lugged pottery ("Naiji" ware)—a finding consistent with recent analysis by Takase (2013) and with the paleodemographic patterns from the Kurils reported below. Based on the continuity of lithic forms from prior Kamchatkan traditions, Dikov goes on to suggest these southern Kamchatkan sites may represent marriage of Ainu women into Kamchatkan (Old Itel'men) communities rather than wholesale settlement of Ainu immigrants. In the early $18^{\text {th }}$ century, Krasheninnikov (1972) makes a similar suggestion that Ainu on Shumshu Island were inter-married with Kamchatkans of Itel'men (Kamchadal) ethnicity.

Caught between the expanding empires of Japan and Russia, the traditional culture of the Kuril Ainu had largely disappeared by the late nineteenth century (Stephan, 1974). Without ethnographic descriptions, the little information we have on Kuril Ainu lifeways comes from historical accounts of explorers and from interviews conducted with Ainu elders. Torii (1919) provides the most detailed account based on visits to the islands in the late nineteenth century. In the northern Kurils, Torii (1919, pp. 22-25) describes a system of seasonal migration between permanent villages on Shumshu, Paramushir and Rasshua islands and smaller fishing camps on Onekotan, Kharimkotan, Shiashkotan, Matua and Ushishir.

\section{Paleodemography of the Kuril Islands}

Archaeological survey and excavations conducted by the International Kuril Biocomplexity Project (IKIP) in 2000 and the Kuril Biocomplexity Project (KBP) between 2006 and 2010 generated a cultural radiocarbon database of 380 archaeological dates, recovered from locations extending across the $1100 \mathrm{~km}$ expanse of the chain from the island of Kunashir in the South to the island of Shumshu in the North (Figure 1, Table 1). These projects collectively documented 108 sites on the 16 largest islands throughout the chain. All sites were identified and tested through surface observation and collection, small shovel tests and/or examination of erosion profile exposures. Charcoal, fauna, artifacts and sediment samples (e.g., tephra) were collected from intact deposits from most sites and as many components as were encountered in excavation. Where house pits or other surface expressions were visible, site plans were prepared depending on available time (sketch maps, GPS maps, and transit maps; Fig. 2). At several large sites, stratigraphy was also recorded by means of $2 \mathrm{~cm}$ diameter soil probes placed both in- and outside of house pit features. Charcoal found in the probes 
was sampled from charcoal-rich 'cultural' strata, and several of the dates reported here come from these contexts (Table 2 for details). While most sites were documented and tested in less than a day of field research, eight sites were more intensively sampled through large-scale excavations over multiple days, involving crews of 10-15 people. These eight sites were notably large and exhibited numerous semi-subterranean house depressions (e.g., Fig. 2). It is likely that some of these sites are classifiable as "villages," pending demonstration of the contemporaneity of their features-an issue we hope to address in a future publication. These sites were investigated to provide greater archaeological insights regarding site organization, chronological ranges and occupation intensity of sites ranging from Urup Island in the south to Ekarma Island in the north-central islands. These eight sites-arranged south to north-are Ainu Creek on Urup, Peschanaya Bay 1 on Chirpoi, Vodopadnaya 2 on Simushir, Rasshua 1 on Rasshua, Ainu Bay 1\&2 (one site) on Matua, Drobnyye 1 on Shiashkotan, Ekarma 1\&3 (one site) and Ekarma 2 on Ekarma. The northern islands of Shumshu and Paramushir and southernmost islands of Kunashir and Iturup were surveyed and several sites identified and tested, but no intensive testing was conducted in these regions by IKIP or KBP.

[Insert Fig. 2: Map of Drobnyye 1 site]

Nine hundred and forty six (946) organic samples were collected for the purpose of radiocarbon dating from 63 out of 108 sites recorded by IKIP and KBP, representing all 16 islands with archaeological discoveries. Three hundred and eighty (380) of these samples-from 57 sites-were submitted to the radiocarbon facilities at the University of Arizona (IKIP's AA dates) and the Woods Hole Oceanographic Institute (KBP's OS dates) for dating. Two hundred and twenty six (226) of these dates come from the eight intensively sampled sites identified above, the remaining 154 dates coming from the remaining 49 sites. Similarly, 237 dates come from the eight most intensively dated sites (these are those sites for which 10 or more dates were assayed, arranged from highest to lowest data frequency: Rasshua 1, Vodopadnaya 1, Drobnyye 1, Ainu Creek 1, Ekarma 1\&3, Kama, Peschanaya Bay 1, and Baikova 1). As shown in Table 1, this sampling protocol was intended to balance between spatial coverage (dating the largest number of sites) and chronological depth (maximizing understanding of the occupation history of single sites). These dates were predominantly derived from wood charcoal, and the paleodemographic model presented below is based exclusively on 364 terrestrial wood charcoal samples, omitting two measured on marine mammal bone, three on charcoal indicating post-bomb ages, and eleven on charcoal collected from the Ainu Creek 1 site that are of questionable provenience due to site disturbance.

[Insert Table 1 here: frequency of dates by region]

One of IKIP-KBP's chief objectives in compiling this radiocarbon database was to establish an empirical basis for modeling variability in Kuril human settlement intensity over time and space. Such models depend on the assumption that variations in the temporal frequency of archaeological deposits can be used as proxy measures of relative changes in human population size over time, under the simple assumption that 
larger populations will tend to deposit a greater abundance of archaeological materials than small ones, all else being equal. This approach to census-taking has become increasingly common following Rick's (1987) study of pre-ceramic Peruvian population dynamics. This is especially true for Europe, North America, and Oceania in papers published over the last 15 years (e.g., Kirch and Rallu, 2007; Peros et al., 2010; Boulanger and Lyman, 2014; Downey et al., 2014; Timpson et al., 2014; Wang et al., 2014; Gayo et al., 2015; Tallavaara et al., 2015; Williams et al., 2015; Zahid et al., 2015; for inventories of the cumulating body of demographic temporal frequency analyses, see Surovell and Brantingham, 2007; Williams, 2012; Brown, 2015; Chaput and Gajewski, in press).

The validity of this approach requires that three conditions be met (Rick, 1987). First, the anthropogenic unit of observation that has been selected for temporal quantification (e.g., the site or site component, domestic feature, quantum of datable organic matter, etc.) must have been deposited at an approximately constant personyear rate over time within the study region, resulting in the formation of a temporal frequency distribution ( $t f d$ ) that is approximately proportional to the region's population over time. Second, while the loss of archaeological deposits to destructive geological forces may be inevitable, those deposits that have survived must have resisted the operation of temporally variable-non-constant-destruction rates such as punctuated episodes of erosion or deep burial. Third, the researcher must collect and establish accurate chronometric control for samples of archaeological deposits in equal proportion to those that exist across the study region.

As fundamental as these three conditions are to the validity of demographic temporal frequency analysis, they are hardly guaranteed. On the contrary, multiple potential sources of error threaten to undermine the validity of such demographic interpretations (Rick, 1987; Brown, 2015: Table 2), particularly those that rely on the strong assumption of proportionality between the shape of the $t f d$ and temporal fluctuations in paleopopulation size. The confounders on such analysis, which may be meaningfully divided into three overarching categories, have been widely discussed elsewhere (Rick, 1987; Surovell and Brantingham, 2007: 1869; Shennan et al., 2013: 3; Timpson et al., 2014: 550; Attenbrow and Hiscock, 2015: 32-34; Brown, 2015: Table 2) and need only be summarized here:

$>$ Creation error: population size-independent fluctuations in the intensity of the original archaeological signal, resulting from temporal variability in the personyear rate at which archaeological deposits have been created (e.g., due to changes in mobility rates, aggregation or disaggregation of residential groups, etc.; Rick, 1987; Surovell and Waguespack, 2008; Downey et al., 2014);

$>$ Preservation error: the differential preservation of archaeological deposits resulting from the operation of both random and systematic processes of deposit destruction (Rick, 1987; Surovell and Brantingham, 2007; Surovell and Waguespack, 2008; Surovell et al., 2009; Ballenger and Mabry, 2011); 
> Investigation error: a wide variety of disproportionate representation factors intrinsic to the research process itself (Rick, 1987). These factors include the level of research intensity, which influences sample size and consequently the degree of random sampling error characterizing the sample tfd (Surovell and Waguespack, 2008; Shennan et al., 2013: 6; Timpson et al., 2014: 550; Brown, 2015: 135-136, 141); discovery or detection bias resulting from the application of particular field data recovery methods that are disproportionately sensitive to deposits of different ages (Ballenger and Mabry, 2011); inclusion or scientific bias resulting from the preferential timestamping of archaeological deposits from particular periods, whether because of the differential intensity at which different sites are dated and/or because sites from particular cultural periods are favored over those from others (Ballenger and Mabry, 2011); age misestimation resulting from the limitations of sample hygiene practices undermining the bridging arguments linking target and dated events (e.g., old wood and marine reservoir offsets; Dean, 1978; Schiffer, 1987; Shott, 1992; Batt and Pollard, 1996; Pettitt et al., 2003; Waters and Stafford, 2007; Kennett et al., 2008; Rieth and Hunt, 2008); and various idiosyncratic errors that characterize particular age estimation methods (e.g., those that uniquely affect ${ }^{14} \mathrm{C}$-supported $t f d s$, summarized in Brown, 2015).

In light of these potential confounders, efforts to produce valid models of paleopopulation growth processes based on tfds must attempt to prevent or at least mitigate their effects to the greatest degree possible. The following discussion describes the measures we have taken toward such ends.

To minimize the degree of target event-dated event disparities, IKIP-KBP field archaeologists focused on the recovery of datable organics that came from unambiguous anthropogenic deposits. As noted above, all dates included in this analysis are limited to those assayed on terrestrial wood charcoal. The "old wood effect" must be considered as a potential bias for dates run on charcoal, since factors like ocean residence time for driftwood, reuse of structural timbers and long-lived tree species can contribute to the artificial inflation of radiocarbon ages. In the study area, it is probable that island residents harvested driftwood for multiple uses, including fuel, in addition to harvesting locally available standing trees and shrubs. Other northern driftwood studies have indicated that logs rarely survive longer than seventeen months in the ocean (Häggblom 1982:Table 1; see Shaw 2008:80-81 for a summary), and longterm reuse of structural timbers is unlikely in this wet environment. The most significant old wood potential, therefore, stems from the burning of long-lived woody taxa - a problem common to most applications of radiocarbon analysis on tree charcoal.

To mitigate the potential effects of old wood on radiocarbon results, Jennie Shaw (n.d.) conducted a brief taxonomic analysis of charred wood fragments from three KBP sites (Rasshua 1, Vodopadnaya 2, and Ainu Creek; Fig. 3). Her analysis indicated that the central island residents of Rasshua 1 and Vodopadnaya 2 used a diverse mix of fuelwoods, including Picea (spruce), Larix (larch), Salix (willow), Populus (poplar), Alnus 
(alder), and perhaps Betula (birch); whereas the more southerly site of Ainu Creek exhibited a reliance on Pinus (pine), with limited use of Salix. Modern and paleoenvironmental studies by Anderson and colleagues (2007) indicate that Picea, Larix, and Populus grew in the southern islands and likely arrived in the central islands as driftwood, while Alnus and Betula may have been harvested as local shrubs or as larger driftwood logs transported from the south. At Ainu Creek, the Pinus was likely a locally harvested shrub (Pinus pumila) and Salix may have been harvested in shrub or tree form. The archaeological charcoal likely derived from shrubs and small trees with short to medium lifespans and would be unlikely to introduce more than 100 to 150 years of "old wood bias" to radiocarbon dates. While modest, this potential "old wood" offset needs to factor into the interpretation of the resulting radiocarbon distributions discussed below, and we could expect distributional patterns to be slightly offset by several decades or a century or so older than their corresponding true ages-an issue of important when comparing them to historically recorded events, calibrated radiocarbon dates derived specifically from short lived, terrestrial organisms, or calibrated dates generated by alternative chronometric techniques.

\section{[Insert Fig 3: Charcoal Identification]}

As discussed above, disparity exists between the dating intensities of the 8 intensively investigated sites identified above (associated with 226 dates, an average of 28.25 dates per site) and the remaining 49 less intensively tested sites (associated with 154 dates, an average of 3.14 per site). At the same time, these eight sites are noteworthy for their exceptional size, reminding us that some sites do in fact represent a greater number of person years, whether occupied by large resident populations for relatively short periods of time, or small populations over extended periods of time, or especially by large resident populations over extended periods of time. As such, a procedure for deposit enumeration and $t f d$ construction was required that balances between the competing needs (1) to capture variability in the person-year weights of different sites and/or at different periods, and (2) to count the proxied person-year no more than once. Toward such ends, we divided each site's radiocarbon assemblage into spatially concentrated clusters (carbon specimens spaced no more than 5 horizontal meters from each other) to minimize the over-representation of intensively dated sites, while simultaneously allowing our sampling of larger sites to contribute greater weight to the $t f d$. The 5-meter horizontal distance rule was applied specifically so that contemporaneous but spatially separated archaeological deposits would be counted separately, under the related assumptions that closely spaced samples are more likely to derive from the same residential unit (e.g., the household and its immediate surrounding, house pits in the area typically ranging 4-6 meters in diameter), and that more distantly spaced samples more likely derive from different residential units. In any case, while the 5-meter rule is an arbitrary threshold, we urge readers not to fixate on this choice vis-à-vis alternative radii. In fact, contiguous test units excavated during the IKIP-KBP field projects rarely exceeded 5 meters in extent, and at sites with multiple excavations, the distance between them was normally well in excess of 10 meters (see Fig. 2). Within the 5-meter horizontal radius, balance between the two needs discussed above was achieved statistically: within this horizontal proximity, we 
identified and pooled clusters of statistically redundant (i.e., insignificantly different) radiocarbon ages, following Ward and Wilson's (1978) method. Ultimately, we take each site's reduced set of radiocarbon age estimates to be broadly representative of the relative temporal frequency of demographic units at that site.

Application of this pooling protocol collapsed 172 individual age estimates into 61 pooled estimates. Consequently, the model presented below is based on a sample of 253 age estimates, including these 61 pooled and the remaining 192 stand-alone dates.

Strategies for identifying and correcting preservation error, and particularly the time-transgressive taphonomic bias addressed by Surovell and colleagues (Surovell and Brantingham, 2007; Surovell et al., 2009), are a matter of ongoing concern for archaeological demographers and critics alike. To date, the best solution to preservation error is to correct tfds for the increasing underrepresentation of successively older deposits by multiplying them by the inverse of model deposit survivorship functions (Surovell et al., 2009; Williams, 2012). While the reliability of this approach has been questioned (Ballenger and Mabry, 2011), the fundamental assumption that sites of younger age are proportionally more likely to be preserved is almost certainly a major contributor to the observed trend toward increasing deposit frequency through time in regional tfds spanning the globe. The Kuril pattern shows a similar overall "growth" trend.

The Kuril landscape is highly dynamic, with volcanic and tectonic processes in particular remodeling and creating new land surfaces. To assess the degree of preservation error that these processes have created, Maclnnes and colleagues (2014) compared the geomorphic ages of landscape features (landslides, pyroclastic flows, etc.) against the earliest archaeological dates recorded upon them. They found little difference between the archaeological profiles of Pleistocene- and Holocene-age landforms, concluding that landscape remodeling (depositional processes) has not significantly biased the available settlement chronology. This finding suggests that our efforts to model Kuril paleopopulation dynamics are minimally confounded by the operation of land surface creation. Even so, we do not claim that the general trend of increasing date frequencies with time is entirely free of preservation error. In particular, Maclnnes and colleagues' study did not control for erosion, and we readily acknowledge that site loss is likely a contributing factor to the long-term trend toward increasing frequencies of younger dates exhibited by the Kuril tfd. Even so, we believe that some proportion of the longer term growth trend is real, as argued below, while the peak and trough structures we describe constitute departures from any long-term, attritional trend and are therefore largely immune to the problem of time-dependent loss of archaeological data.

\section{[Insert Fig. 4: Paleodemographic curve]}

Figure 4 presents a tfd-based paleopopulation size model for the Kuril Islands based on the IKIP-KBP radiocarbon database. The sample tfd (thin line) is a summed probability distribution ( $s p d$ ), a category of $t f d$ that controls for age estimation imprecision by summing up the probabilistic expression of each timestamp in the sample as these expressions vary along the timeline (Table 2 and Supplement). To 
minimize the influence of investigation bias on this model, our sample includes only radiocarbon dates collected as a part of IKIP-KBP fieldwork.

As discussed elsewhere (Brown, 2015, and citations therein), both random and systematic error characterize radiocarbon-supported spds, the former resulting from the operation of stochastic processes in the generation of radiocarbon assemblages, the latter from DeVries effects (secular variation on the concentration of atmospheric radiocarbon; Sonett et al., 1990) that have led to a nonlinear relationship between calendric and radiocarbon ages. As a side effect of efforts to control for DeVries effects through calibration, radiocarbon-supported spds typically exhibit many artificial shortduration structures (spikes and troughs) whose amplitude is modulated by the varying intensity of the stochastic processes, sample size being particularly influential here (Brown, 2015). To mitigate the presence of these artificial structures, fine-scale variation in the spd is smoothed away using kernel density estimation techniques, which in this case is tantamount to the application of a moving, distance-weighted average (for further discussion of kernel density estimation and formal details of its implementation here, see Supplement). The smoothed distribution that results (Fig. 4, heavy black line) is expected to more closely approximate the shape of the population curve underlying the sample $t f d$ (in this case, the $s p d$ ) than does the sample tfd itself. The reconstruction of the Kuril paleopopulation history presented below is based on this distribution of kernel density estimates $(K D E)$, not the raw spd.

[Insert Table 2 - radiocarbon data]

\subsection{Kuril Population Trends}

The presence of diagnostic pottery and a few radiocarbon dates from other projects (not included in Fig. 3 to ensure methodological consistency) indicate that the southernmost Kurils were occupied as early as 8000 cal BP (Yanshina et al., 2009; Yanshina and Kuzmin 2010) during the late Initial Jomon and through the Early and Middle Jomon periods (Samarin and Shubina, 2013). From the evidence reported in Table 2, an earlier-though not as early-occupation also appears likely in the northernmost islands of Shumshu and Paramushir, near Kamchatka. A charcoal sample from intact stratigraphy in the Baikova 1 site dates to ca. $6000 \mathrm{cal} \mathrm{BP}(5290 \pm 35$ rcybp, OS-97898; Table 2), though more investigation needed to evaluate the context and cultural association of this date. A Kamchatkan source for this occupation may be indicated by the discovery of stone artifacts common to the Kamchatka Neolithic that we found in 2006 on Paramushir Island, at the Trudnaya 1 site and the Savushkina 2 site (Fig. 5a and 5b). Unfortunately these lithic finds were collected from surface contexts and are undated. It is reasonable to assume that people would have first come to the northern-most and southern-most islands from the adjacent mainland coasts without moving into the more remote islands, an interpretation consistent with the evidence reported here.

[Insert Fig. 5- lithic tools]

As argued above, Figure 4 models changes in occupation intensity in the Kurils following their colonization. Examination of this model suggests five episodes or trends 
in the region's population history. The first trend (" 1 " on Fig. 4) is one of limited growth from earliest settlement to 3500 years ago. In that time, growth concentrated predominantly in the southern islands close to Hokkaido.

The second trend ("2" on Fig. 4) is initiated with the oldest radiocarbon evidence for human presence in the remote (South Central and North Central) Kurils at approximately $3500 \mathrm{cal}$ BP. The earliest archaeological diagnostics in the remote islands are attributed to Late Jomon culture, consistent with these earliest dates. These data suggest a development of more maritime focused lifestyles and a demographic expansion across the Kurils at this time. The timing of this development is consistent with a broader shift towards coastal adaptations around the northern Sea of Okhotsk and Bering Sea (Fitzhugh, in press). This timing also follows a broader pattern found in many parts of eastern Japan wherein site numbers decreased dramatically at the end of the Middle Jomon, then began to increase again in the second half of the Late Jomon phase. On the mainland of eastern Hokkaido, for example, hardly any sites are known from the first half of the Late Jomon (Utagawa, 2008, p. 17). This Middle-Late Jomon population trend is often linked with climatic cooling, although few researchers have discussed how environmental change actually impacted Jomon society (cf. Kawashima, 2013).

Our radiocarbon data suggest accelerating and increasingly consistent growth following population movement into the remote islands (ca. 3500-1900 cal BP), spanning the Late and Final Jomon and early Epi-Jomon periods. Growth between 2500 and $2000 \mathrm{cal} \mathrm{BP}$, in particular, appears to have occurred at a rapid rate of approximately $0.2 \%$ per year (see Supplement for details regarding growth rate estimation), then slowing over the next century to $0 \%$ annual growth, with the population peaking ca. 1900. It is noteworthy that the high and sustained level of growth observed between 2500 and 2000 lies near the upper limit of intrinsic growth observed among ethnographic hunter-gatherer populations, suggesting that this period of growth was fueled in part by an immigration subsidy (Collard et al., 2010). We found Late Jomon pottery (Fig. 6) as far north as Urup Island and Epi-Jomon pottery throughout the southern and central archipelago north to the Drobnyye 1 site on Shiashkotan Island. Valery Shubin (personal communication to B. Fitzhugh) reports seeing Epi-Jomon pottery at the Savushkino 1 site on northern Paramushir in the 1970s. This observation is consistent with the appearance of Kamchatka obsidian in Epi-Jomon assemblages throughout the northern and central Kurils (Phillips, 2011) and indicates that Epi-Jomon culture bearers traded with Kamchatka communities-or, less likely, mined their own Kamchatka obsidian well before $2000 \mathrm{cal}$ BP. Epi-Jomon settlements are ubiquitous throughout the central Kurils, and in many locations their relatively small, single-room house pits are the most prevalent features across large multi-component sites, evident from both diagnostic pottery and radiocarbon dates from soil probe samples in house pits across several sites.

[Insert Fig. 6: pottery photo] 
The third notable trend in the paleodemographic model (" 3 " on Fig. 4) is the decline in population at the end of the Epi-Jomon occupation, starting ca. 1900 cal BP and reaching its nadir by ca. $1400 \mathrm{cal} \mathrm{BP}$, declining by $33 \%$ at a relatively gradual average rate of approximately $-0.08 \%$ per year. Because this decline began hundreds of years before Okhotsk expansion into Hokkaido (ca. 1500 BP: Amano 2003) and the Kurils (ca. 1300 cal BP: Yamaura and Ushiro, 1999), it cannot be attributed to Okhotsk contact. The $1400 \mathrm{cal}$ BP inflection in Fig. 4-though a century earlier than the reported age of Okhotsk expansion-may represent the influx of Okhotsk population if the paleodemographic model is offset by old wood dates, as described above, or if the earliest published dates on Okhotsk expansion in Hokkaido are of limited accuracy. In any case, some Kuril Epi-Jomon communities likely remained to witness the expansion of Ohkotsk culture into and through the Kurils, but if so, they were a remnant population. We speculate that Okhotsk colonization was made possible by centuries of prior EpiJomon decline. There is no evidence at present to suggest conflict between the groups, despite Okhotsk use of defensive fortifications in the southern islands and on Hokkaido and Sakhalin (Samarin and Shubina, 2007). No such fortifications were identified in the central or northern Kurils. We suggest that the transition from Epi-Jomon to Okhotsk involved minimal population displacement, perhaps because few Epi-Jomon communities remained in the Kurils at this time. Possibly Epi-Jomon and Okhotsk groups co-existed peacefully-at least in the southern region, where after 300 years a syncretic (Tobinitai) culture developed with ties to both ancestral groups.

The fourth and fifth trends are defined respectively by the growth (ca. 1400-900 cal BP) and subsequent decline of population (900-450 cal BP). In this half millennium, the Kuril Okhotsk population grew to rival or exceed the Epi-Jomon population peak a millennium earlier ("4" on Fig. 4), though paradoxically requiring less effort per capita to achieve such size (approximately $0.13 \%$ per year). From archaeological evidence, we know that the Okhotsk settled the entire Kuril chain as far as the southern tip of Kamchatka (Dikova, 1983). As shown below, obsidian source studies indicate that most obsidian used by central and northern Okhotsk communities in the Kurils came from Kamchatka. In contrast to the gradual pace of the earlier, Epi-Jomon decline, the Okhotsk population appears to have collapsed precipitously between 900 and $450 \mathrm{cal}$ $\mathrm{BP}$, decreasing by $57 \%$ at an average rate of approximately $-0.19 \%$ per year ("5" on Fig. 4).

Surprisingly to us, Ainu occupation in the Kurils was elusive. We had expected to find Ainu occupation replacing Okhotsk within a short interval, but the dates in Fig. 4, diagnostic artifacts and house features all suggest the islands were largely empty of settlements for two hundred or more years, being re-occupied by Ainu communities within a century or two of direct Russian and Japanese arrival and documentation. When they did settle the islands, Ainu appear to have been more directly engaged in extraction of resources for trade (Fitzhugh, 2012).

\section{Explaining Kuril Population Trends}

\subsection{Environmental Hazards}


Environmental variability is often invoked to account for changes in the archaeological trajectories of hunter-gatherers, and we begin our exploration of the possible causes for Kuril population fluctuations with a discussion of the environmental factors that might have negatively (or positively) affected Kuril settlement. The most evident environmental factors include natural hazards such as volcanic eruptions and tsunamis, as well as changes in the climate and marine ecosystem that would have affected mobility and subsistence (Fitzhugh, 2012).

Located on the active Kuril-Kamchatka subduction zone, the Kuril Islands have experienced at least thirty-three volcanic eruptions in the last 300 years, with twenty erupting in the last seventy years alone (Nakagawa et al., 2008; Ishizuka, 2001). Nakagawa and colleagues (2008) report approximately eighty volcanic eruptions across the island chain in the last three millennia, including two caldera eruptions (Medvezhya on Iturup in the southern islands and Ushishir in the central islands) and four large Plinian eruptions (Zavaritsky once and Sarychev twice in the central and Severgina, three times in the northern islands) (see Fig. 4). In addition, Nakagawa and colleagues (2008) identify periods of greater and lesser Kuril volcanic activity throughout the Holocene, with some of the most intense eruptive intervals falling during the Epi-Jomon population explosion.

Despite the occurrence of hazard events during periods of high population density in the Kuril Islands, there is little evidence to suggest these events precipitated population decline. As highlighted in Fig. 4, major eruptions in the Kuril archipelago occur at various phases of population growth and decline. The caldera-forming Medvezhya (ca. 2400 cal BP) and Ushishir (ca. 2200 cal BP) eruptions occurred during episodes of population growth, which appear to have continued unabated despite these eruptions. Most eruptions, including many of the large ones, would have had only local impacts, leaving the majority of the Kuril population unaffected, perhaps requiring only adjacent communities to move away temporarily. It is fair to speculate, however, that the impact of eruptions may occasionally have been extensive enough to precipitate changes in the course of population growth, so it may not be a coincidence that either the Epi-Jomon or the Okhotsk population decline (or both) initiated soon after major eruptions. Conversely, the reoccupation of the Rasshua 1 site immediately atop the thick Ushishir tephra soon after that caldera eruption suggests a relatively benign impact (Fitzhugh, 2012).

The tectonic environment of the Kuril archipelago also generates numerous earthquakes and related tsunami events. Geological data collected over the last sixty years demonstrates the occurrence of at least thirty-four earthquakes and related tsunami events within the Kuril archipelago (NGDC, 2013). Analysis of paleo-tsunami deposits indicates that similar events likely occurred in this region throughout the Middle and Late Holocene (Maclnnes et al., 2009). Colleagues continue to work on the quantification of earthquake and tsunami frequency and intensity from field studies. Preliminary indications are that major tsunami events recur at any given location (but especially on the Pacific side and near passes) every $100-200$ years. Considered as a whole, the archipelago might see a major tsunami somewhere along its extent every several decades. If past residents of the archipelago were in contact with each other, as we expect they were, it is likely that they were aware of the risk of tsunami events and 
consequently took efforts to protect themselves and their critical infrastructures (boats and houses). As noted elsewhere, the placement of settlements on elevated terraces suggests effort to avoid direct tsunami impacts (Fitzhugh, 2012). Damage to marine ecosystems from tsunamis may have been fairly temporary and most often isolated to the Pacific sides of the islands. Thus, opportunities would normally exist to move to the Okhotsk Sea side to find unaffected resource zones, though increased human competition for those remaining resource patches might be an expected outcome if the islands were heavily settled.

\subsection{Climate Change}

Fluctuations in climate could have had direct or indirect effects on the dynamic population history of the Kuril Islands. Boat travel-a necessity for foraging and connecting with neighbors-would have been more risky in stormier periods, and a range of climate variables could change the ecological character and productivity of nearshore marine ecosystems. Research is still needed to meaningfully characterize the mechanisms linking climate trends and their implications for travel and subsistence during the mid to late Holocene. Here we report the more general climate patterns revealed by paleoclimate research conducted under the umbrella of the Kuril Biocomplexity Project.

Paleoclimatological proxy data from a number of sources on or near the Kurils point to major fluctuations in temperature and aridity through the Holocene. Pollen analysis from peat excavations and lake cores in the Kurils show major changes from the early to late Holocene, with sea level highstand marking the Holocene Optimum between 7500 and 6600 cal BP (Lozhkin et al., 2010; Razjigaeva et al., 2013). The late Holocene was generally cooler and stormier than the early Holocene, with a more active and variable Aleutian Low pressure system dominating winter weather in the North Pacific. This pattern resulted in more intense cold and dry winds off the Siberian mainland, a frozen Sea of Okhotsk in winter, and generally more stormy conditions overall. At the same time, warm tropical waters could be pushed north along the Pacific coast of Japan-sometimes reaching the southern Kurils - creating more mild conditions in that region (Razjigaeva et al., 2013, pp. 135).

Expansion of human settlements into the central Kurils follows mid to late Holocene "Neoglacial" cooling trends, while the most extreme cold intervals coincide with declines in population (Fig. 4). Razjigaeva and colleagues (2013) report the following mid to late Holocene trends, which we compare to the paleodemographic observations reported above:

$>$ After the Holocene Optimum, a brief cooling is evident from 5400-5000 cal BP (4700-4500 $\left.{ }^{14} \mathrm{C} \mathrm{BP}\right)$. This cooling was most prominent in the central Kurils, while temperatures remained relatively warm in the South Kurils.

$>$ From $5100-3400$ cal BP $\left(4500-3200{ }^{14} \mathrm{C} \mathrm{BP}\right)$, the Kurils warmed again, especially in the southern islands, and precipitation increased. Jomon expansion into the central islands occurred toward the end of this phase, though human population numbers remained low. 
> From 3400 to $2400 \mathrm{cal} \mathrm{BP}\left(3200-2400{ }^{14} \mathrm{C} \mathrm{BP}\right)$, the Kurils cooled by as much as 2-3 degrees $C$, and precipitation resulted in heavy winter snow cover. Stronger than previous southerly spring and summer winds are indicated by the presence of windblown pollen from 2750 years ago to present. During this period, the pace of Epi-Jomon population growth appears to have gradually increased from nearzero values, to approximately $0.2 \%$ between 2500 and 2000 cal BP. However, it is also worth noting that population growth gave way to decline after ca. 1900 as this cooling trend continued.

$>$ The cooling trend intensified to its maximum during the interval $1650-1200 \mathrm{cal} \mathrm{BP}$ (1760-1270 $\left.{ }^{14} \mathrm{C} \mathrm{bp}\right)$. Over this period, conditions were not only cold but also drier than previously, suggesting a southerly extension of the cold Oyashio current and dry, cold winds off the frozen Sea of Okhotsk in winter. The end of the EpiJomon decline and the subsequent initiation of the Okhotsk growth occurred during this interval.

> From 1200-670 cal BP (1270-700 $\left.{ }^{14} \mathrm{C} \mathrm{BP}\right)$, a warm trend prevailed, especially on the continent, while the Kurils experienced mild warming to just slightly above late $20^{\text {th }}$ century/early $21^{\text {st }}$ century ("modern") averages. The Okhotsk expansion into and throughout the Kurils continued during this period, but also the warm trend persisted through the onset of the archipelago's most dramatic period of population decline.

$>$ Cold winters, cool summers and high precipitation dominated the interval from 670 to 100 years ago or so. Temperatures declined $1-2$ degrees $C$ and the cold Oyashio once again appears to have pushed south, though high precipitation indicates prevailing winds coming from open water. Mild regression of the sea level once again exposed unconsolidated sand, and dunes were built in the southern Kurils. The rapid and dramatic population decline that had initiated at the end of the previous warm interval continued for another two centuries as the weather turned cold, accompanied by the disappearance of the Okhotsk culture from the Kurils. Conversely, the end of population decline and the arrival of the Ainu into the Kurils likewise transpired before the climate had yet rebounded. This late population appears to have persisted at a modest but stable size up to the period of contact with Russia.

It is tempting to see a relationship between late Holocene climate and population trends in the Kurils. While the remote islands were only significantly occupied after the end of the Holocene Climatic Optimum, possibly hinting at poor conditions associated with extreme warming, human populations appear to have achieved peak sizes during the moderately cool periods that characterized the late Holocene's Neoglacial period, and may have declined or completely abandoned the remote islands in the coldest periods (Fig. 4). These relationships could be clarified with higher resolution climate data and better understanding of the mechanistic links between climate and maritime hunter-gatherer welfare in the region.

Recent research in Pacific oceanography suggests that colder temperatures around the North Pacific Rim (especially the Gulf of Alaska and eastern Aleutians) may lead to enhanced marine productivity through production of fattier planktons and more 
robust forage fish stocks (Trites et al., 2007). Other data suggests that some taxa (such as cod, pollock, and anchovies) do better-in some areas at least-with warmer waters and stronger Aleutian Low pressure conditions (Chavez et al., 2003). Overall, it is likely that environmental factors played an important role in the settlement, habitation and abandonment of the Kuril Islands but these factors require more study. We believe the environmental variables are important but incomplete aspects of the human settlement story. Hunter-gatherers are known to have a number of strategies available to mitigate environmental variability and uncertainty (Fitzhugh et al., 2011; Halstead and O'Shea, 1989; Wiessner, 1977). We think the story is more complicated, specifically because it also involves social dynamics in play at various spatial scales.

\subsection{A Network Approach}

Islands are especially difficult places for hunter-gatherers to settle and most islands were in fact first colonized by agricultural populations (Cherry, 1981; Takamiya et al., 2015). The Kurils are one important exception to this generalization. To make better sense of the Kuril settlement history, we propose the following framework to explore the Kuril population trends identified above. Specifically, we suggest that the formation of and reliance on social networks played a key role in both stabilizing populations during moderate environmental turbulence at one spatio-temporal scale while increasing vulnerability to environmental and socio-economic fluctuations at larger spatial scales. Drawing from an information-networks model presented by Fitzhugh and colleagues (2011), we propose that during periods of expansion and colonization of novel landscapes, extensive social networks are likely to be in demand as they provide access to regional information, marriage partners and resources that are crucial when uncertainty about the new environment is at its highest and populations low. In the Kuril Islands, this would occur when populations first expand into the more remote central islands during the early portion of the Epi-Jomon and the early half of the Kuril Okhotsk occupation (which coincides with the Middle Okhotsk in Hokkaido). However, after the period of initial colonization and 'settling in,' environmental uncertainty should decrease through individual learning and collective experience within the new environment (accumulation of local and traditional knowledge). At this point, social networks might either be maintained or reduced. Despite the high costs of extensive social networks, they should be maintained for communities living in sparse and highly unpredictable and hazardous environments (Fitzhugh et al., 2011). Network contraction is expected under most other conditions, where network costs are reduced by trimming the most expensive connections in proportion to greater understanding of and local adaptation to environmental variability (development of local knowledge systems). We expect that partners living farthest away are most likely to drop out of such contracting networks first.

Our initial prediction is that the networks of the Jomon/Epi-Jomon and Okhotsk would have become smaller and more isolated over time as growing experience with the landscape lowered the perceived value of social contacts from beyond the local area. This would be true unless the Kurils were chronically vulnerable so that networks remained essential for dealing with occasional local insufficiencies. In this case, the increased security of the extensive social network could be counter-balanced by unintended consequences of being dependent on that larger network. These 
unintended implications include susceptibility to external forces or hazards, such as diseases (McGovern et al., 1988), changes in the economic and political dynamics affecting other parts of the network, and the potential loss of self-sufficiency due to an increased reliance on non-local materials. In fact, in some cases trade and information once integral to expansion or population growth could later become significant hazards in their own right. In essence, island-living could put remote communities into a precarious balance between managing local environmental hazards and non-local social hazards.

\subsection{A Tale of Two Networks}

Based on archaeological and historical evidence, we argue that the Epi-Jomon and Okhotsk occupations of the remote Kuril Islands developed two somewhat different social network strategies that contributed to their different population histories (Gjesfjeld, 2014). Throughout the Epi-Jomon-well after ancestral Jomon settlements were established in the islands-networks appear to have had limited extent. These networks nevertheless served to insulate Epi-Jomon communities from short-term impacts. For the Okhotsk, by contrast, regional networks were more extensive, and continued well after colonization-potentially for economic benefits-in ways that may have led to an over-dependence on non-local assistance in times of local crisis. While neither strategy prevented decline, the rate of population loss was significantly different in each case, with the Epi-Jomon experiencing a gradual population decline over 300400 years while the Okhotsk disappeared completely in less than 100 years.

As detailed elsewhere (Phillips and Speakman, 2009; Phillips, 2011; Gjesfjeld and Phillips, 2013; Gjesfjeld, 2015), evidence for changes in Epi-Jomon and Okhotsk network structures are based on a series of geochemical sourcing studies using both obsidian and pottery. The use of multiple material types is advantageous in this research as they highlight exchange patterns of differing intensities at different spatial scales. Because obsidian is not found locally in the island chain but can be acquired nearby in Hokkaido or Kamchatka, the sourcing of obsidian throughout the islands is informative of exchange and connections to regions beyond. In contrast, raw clay deposits needed for making pottery are found throughout the central islands with geochemical differences that discriminate clay sources from different regions of the archipelago (Gjesfjeld, 2014). As a result, pottery sourcing studies are more indicative of connections over local or regional scales. These sources, when taken in tandem, allow us to draw conclusions about the scale and intensity of social networking within and beyond the island chain.

Our interpretation of Epi-Jomon network contraction in the central islands is based on this combination of pottery and obsidian evidence. The geochemical sourcing of pottery from the central islands suggests a highly localized network structure. At the site of Rasshua 1, located on the central island of Rasshua, 25 sherds classified as EpiJomon (based on presence of cord-marking and consistent with radiocarbon dates) were analyzed for trace elements. A high proportion of sherds (88.5\%) had significantly similar geochemical signatures. Using the criterion of abundance postulate (Bishop et al., 1982), we interpret these results to indicate that most ceramic artifacts were locally produced. The remaining sherds $(11.5 \%)$ are considered non-local or imported to the 
site. It is intriguing to note that two thirds of the non-local sherds from Rasshua 1 originate from the lowest levels of the site (Level $7 \mathrm{C}$ and 8) suggesting an importation of pottery to the site during its initial settlement.

Lithic analysis of obsidian recovered from Epi-Jomon contexts in the central islands (including Rasshua) also indicates a very low usage of (non-local) obsidian $(0.6 \%$ of total by mass) compared to the overall lithic assemblage, which is dominated by local basalts $(59.3 \%)$ and cherts $(28.5 \%)$. Based on results from the geochemical sourcing analysis of obsidian artifacts, during the Epi-Jomon period central island inhabitants equally procured obsidian from both Hokkaido (52\%) and Kamchatka (48\%) sources. Unfortunately, based on the resolution of the data we are unable to determine whether procurement networks to both Hokkaido and Kamchatka were in use at the same time or whether Epi-Jomon inhabitants changed their procurement networks while occupying the central region. The finding that northern island obsidian comes predominantly from Kamchatka and southern island obsidian from Hokkaido does imply that the overlap in the central islands was connected and concurrent with the larger pattern.

Compared to the low level of Epi-Jomon interaction, exchange during the Okhotsk occupation tends to be less localized. Results of pottery sourcing at the site of Vodopodnaya 2, on the island of Simushir, suggest that more Okhotsk pottery was nonlocally produced than that of Rasshua 1's Epi-Jomon deposit. Based on geochemical analysis of 25 sherds (all identified as Okhotsk), only $24 \%$ of sherds demonstrated similar geochemical signatures that could be interpreted as locally produced pottery, with $76 \%$ of pottery potentially manufactured non-locally. Overall elemental variability in clay is higher at the site of Vodopodnaya than Rasshua, but not high enough to account for the difference in pottery assigned to a local group, suggesting these differences are indicative of more imported pottery (Gjesfjeld, 2014).

Obsidian in the central islands is also found in higher relative abundance during the Okhotsk period, with a small but higher proportion (1.9\%) of the total lithic assemblage. However, even though Okhotsk culture originates in northern Hokkaido and southern Sakhalin, almost all obsidian raw material in the central islands comes from Kamchatka during this period. While this finding does not rule out exchange relationships with Hokkaido populations-and our sample of Okhotsk materials from the southern islands appears to be artificially low-it does suggest exchange relationships with Kamchatka may be more important on average in this period. In sum, Okhotsk populations appear to have been dependent on non-local contacts in terms of their overall use of pottery and non-local raw material. The northerly focused obsidian trade may be indicative of a loss of social network support to the south-a development that may have ultimately led to the collapse of the occupation even while possibly insulating it from some threats to the south.

\section{Discussion--Social Dependency in Relative Isolation}

Our research indicates that people colonized all of the Kuril Islands by no later than 3500 years ago, expanding in population more or less continuously for the next 1500 years during the Late/Final Jomon and Epi-Jomon periods. During this expansion, 
long-distance social networks were established and maintained with both Hokkaido and Kamchatka neighbors, as indicated by obsidian raw materials sourced to both regions. Nevertheless, these communities maintained largely self-sufficient lifestyles and the predominant scale of interaction/mobility was with neighboring islands, indicated by the more local scale for pottery source catchments and the social interactions that would flow across them. Interestingly, the dominant source areas of obsidian appear to have been the ones in closest proximity (Kamchatka or Hokkaido). We see this as a reflection of the high cost of travel and tendency to look for the closest sources of raw materials.

These data suggest a healthy balance of local adaptation and the ability to deal with seasonal to inter-annual, localized resource variability. This is expected for selfsufficient populations with established local and traditional knowledge about their place, who nevertheless rely on larger social networks for occasional trade and maintenance of social contacts. Living above the reach of most tsunamis, moving periodically to avoid local resource failures or volcanic eruptions, and developing traditional knowledge about how to find food in difficult times may have limited the necessity of more regularized, long-distance interactions. The combination worked for millennia.

The decline of Epi-Jomon settlements was gradual (-0.08\% per year), transpiring over the half-millennium from ca. 1900 to about 1400 cal BP. This decline cannot be attributed to conflict with Okhotsk people who showed up in Eastern Hokkaido and then the Kurils, centuries after the onset of Epi-Jomon decline. The gradual pace of population loss also implies that the cause was not a catastrophic event such as a major tsunami or short term ecosystem crash of the sort that could be mitigated through the temporary reliance on distant exchange partners. We conclude that the low level, long-distance social networking inferred from the obsidian distributions was effective in allowing for such mitigation. The decline of the Epi-Jomon may instead relate to deterioration of living conditions in the Kurils of the sort that could emerge from a sustained change in ecological productivity due to climate change, or alternatively, people may have been lured away by the development of new opportunities in Hokkaido associated with trade opportunities through Hokkaido and Honshu or the development of minor food production economies (millet and barley) to the south. In either case, possible causal mechanism/s for this decline are not easily identified beyond the simple correlation of population decline and the onset of cold conditions in the late Epi-Jomon.

While the subsequent expansion of the Okhotsk cultural group into the Kurils (ca. $1400-900$ cal BP) appears rapid in Figure 4, the growth unfolded at a more gradual rate $(0.13 \%)$ than seen in Final Jomon/Epi-Jomon expansion 1000 years earlier. The estimated Epi-Jomon growth rate of approximately $0.2 \%$ per year falls near the upper boundary of growth rates exhibited by ethnographically known hunter-gatherer populations and suggests a supplement of immigrants (Collard et al., 2010), while the Okhotsk rate falls much more comfortably within the hunter-gatherer range and could have been sustained intrinsically. We do not believe this was intrinsic growth, in fact, because other archaeological data strongly supports a replacement of Epi-Jomon with culturally unique Okhotsk material culture and population. In any case, the rate of loss at the end of the Okhotsk settlement was quite rapid $(-0.19 \%$ between ca. 900 and 450 cal BP), resulting in an approximately $57 \%$ population reduction over this 450 -year interval. 
To further explore possible causes for the Okhotsk collapse, we need to introduce the concept of the expanding "East Asian World System," of which the Okhotsk cultural phenomenon sat on the margins (Hudson, 2004). First, we think it likely that the galvanization of the Okhotsk 'culture' in the western Sea of Okhotsk region was stimulated - at least indirectly — by political-economic developments in adjacent regions of mainland East Asia. In particular, emerging polities of Manchuria (Heishui or Black Water Mohe) and Bohai (Parhae) kingdoms sought to profit as intermediaries in commodities markets linking wild products from the Sea of Okhotsk and elite markets of more densely settled (and commodities hungry) Korea and China. Demand for trade in exotic commodities was growing and hunter-gatherers of the Sea of Okhotsk were in a position to supply products in return for access to exotic goods including ironware, rice, cloth, alcohol, and weapons (Amano et al. 2013; Smale 2014; Yamaura 1998).

The first millennium C.E. in the western Sea of Okhotsk area is characterized by predominant population movements from north to south as peripheral groups expanded in search of iron and agricultural products. The formation and expansion into Hokkaido of the Okhotsk culture can probably be connected with this trend. However, while their contemporaries, the late Epi-Jomon and Satsumon cultures were increasingly influenced by goods and practices imported from Japanese society to the south, the Okhotsk appear to have been much less engaged in the trade for distant goods (Hudson, 2004). It is unclear whether Okhotsk families who reached Hokkaido and the Kurils were seeking uncontrolled territory to procure trade items, or else were trying to escape the heavy hand of domineering chiefs, whose control of hunting grounds and trade routes and whose pursuit of power made life hard for subordinates. In any case, relatively few durable trade goods from political centers of Japan and East Asia are found in Okhotsk sites in Hokkaido and the Kurils. Despite this, Segawa (2005) has argued that trade was the original motivation for Okhotsk migrations south into Hokkaido. Several early Okhotsk culture sites, such as Aonae on Okushiri Island, are found down the Japan Sea side of Hokkaido, a coast which was always the center of premodern trade between Japan and the north. That these Okhotsk people may have explored as far south as Sado Island is suggested by the following entry in the Nihon Shoki for the year 544: "At Cape Minabe, on the northern side of the Island of Sado, there arrived men of Su-shen in a boat, and staid there. During the spring and summer they caught fish, which they used for food. The men of that island said they were not human beings. They also called them devils, and did not dare to go near them" (Aston, 1972, II, p. 58). Although in early Chinese texts, the term "Su-shen" usually refers to a Tungusic people living in Manchuria, later entries in the Nihon Shoki use this name for a people living in Hokkaido who were attacked by the Japanese state in the 7th century and many scholars link these Su-shen with the Okhotsk culture (Segawa, 2011, p.4981).

By the 8th century, the Okhotsk expansion south along the Japan Sea coast had come to an end as groups of Japanese farmers moved from the northern part of Honshu into the Ishikari plains of southern Hokkaido. Mixing with the Epi-Jomon, these groups formed the Satsumon culture. Segawa (2005, p. 55) argues that this Satsumon expansion made it difficult for the Okhotsk people to continue their previous activities in western Hokkaido and that consequently their area of settlement became limited to the Sea of Okhotsk coasts of eastern Hokkaido. Okhotsk communities continued to have 
some access to commodities traded out of centralized Japan, accounting for the use of Honshu iron in Late Okhotsk smelting (Amano et al., 2013). But obsidian and other lithic resources were still widely used to make tools in the Late Okhotsk whereas the Satsumon culture had completely shifted to the use of iron by that time. The greater access to distant markets possessed by the Satsumon people would without doubt have had significant impacts on the Okhotsk culture, potentially insulating or excluding the latter from economic developments in the broader World System. However, it is not clear whether the vibrant maritime adaptations developed by Okhotsk groups who migrated east and settled the regions around the Shiretoko and Nemuro Peninsulas and who-presumably - seeded and later networked with the populations that soon after filled the Kurils were looking for new sources of exploitable trade items or just a place to escape exploitative market demands in less insular places.

Based on our evidence, once in the Kurils the Okhotsk pursued more social interaction over distance than their Jomon/Epi-Jomon predecessors. Our data are incomplete on this count because our samples do not include Okhotsk materials from the southern islands, but we believe that Okhotsk settlement in the Kurils likely retained strong connections with kindred communities in Eastern Hokkaido for several centuries. Okhotsk settlements are known from the southern islands based on surface collections of diagnostic pottery and limited excavations. In any case between about 1000 and 700 years ago, something disrupted these connections, whatever they were, something that rendered the occupants of the remote and northern Kurils especially vulnerable.

We consider two alternative scenarios. First, the remote islanders could have been abandoned in their trade networks by neighbors in the southern Kurils and Hokkaido. Between 1000 and 700 years ago, Okhotsk occupants in these more southerly regions became increasingly incorporated into interior-focused Satsumon traditions (Tobinitai phase: Hudson, 1999; Onishi, 2003). Since Satsumon communities were much more engaged in commodities trading with mainland Japan, their expansion into Eastern Hokkaido and incorporation of Okhotsk communities there would have been accompanied by increased opportunities to participate in that trade. Since Japanese markets of the day were particularly focused on interior forest and stream products, and not marine goods, the absorption of southern Okhotsk communities could have decreased the need or interest for those communities to engage in reciprocal social and trade networks with remote Kuril groups. Segawa (2012, p. 83) has argued that from the tenth century, Satsumon groups began to move into eastern Hokkaido in search of eagle feathers that were traded for fletching arrows. After the development of the hybrid Satsumon-Okhotsk culture known archaeologically as the Tobinitai, people living in the remote and environmentally tenuous central and northern Kurils may have found themselves cut-off from trade networks linked to eastern Hokkaido to the south. This reduction in access to social networks would have rendered Kuril communities especially vulnerable just as colder climate triggered changes in the frequency and intensity of ecological crises. Newly formed social networks with Kamchatkan neighbors to the north (presumably the ancestors of the Itel'men/Kamchadals) may not have been sufficient to weather these crises.

A second scenario-equally plausible, not mutually exclusive, and harder to evaluate_relates to the increased probability of exposure to communicable diseases 
when engaged in more extensive social networks. The Great Smallpox Epidemic of 735-737 C.E. ravaged western Japan, perhaps killing 25-35 percent of the total population, with mortality in some regions exceeding 60 or 70 percent (Farris, 1985; Suzuki, 2011). By the medieval era, smallpox became less virulent in urban Japan, but would have remained lethal to small populations in remote locations, once contacted. The first recorded smallpox epidemic in Hokkaido is not until 1624 (Walker, 2001, p. 181). However, given that regular contact had been occurring between mainland Japan and Hokkaido from much earlier times, it is possible that there were medieval epidemics that went unrecorded by Japanese authorities. Thus, it may not be a coincidence that the Kuril Okhotsk population collapsed catastrophically, just as their neighbors to the south were becoming more engaged in trade and social networks oriented to Japan.

We do not know for certain how Okhotsk and Kamchatkan communities got along, but the loss of networks to the south may have increased the pressure to engage with Kamchatkan groups when natural hazards or ecological downturns affected life in the remote Kurils. It is also possible that Kamchatka served as a refuge to those forced to leave the remote islands, though no Okhotsk settlements have been found along the coasts of Kamchatka. We suspect that the decline in social connections to the south and tenuous connections to the north made persisting in the Kurils particularly precarious for Okhotsk occupants after 700 years ago when Little Ice Age cooling increased the probability of severe bad years.

In sum, we propose that the Kuril Okhotsk were made increasingly isolated in the $13^{\text {th }}$ century C.E. in way that made them more vulnerable to environmental hazards that they could no longer mitigate successfully with help from social networks. This could have occurred because southern neighbors lost an economic incentive to support their northern neighbors and/or because epidemic diseases wiped out southern trading partners or Kuril Okhotsk communities themselves. Cut off from southern contacts and lacking the bonds of common culture or kinship with Kamchatkan populations, social safety networks along with their complementary ecological benefits deteriorated, leaving the Kuril Okhotsk more vulnerable to natural hazards and years of resource failure or storminess. In this scenario, rapid cooling (experienced as an increase in the frequency of particularly cold years) would have been disproportionately hard on Kuril Okhotsk communities and a combination of catastrophic mortality, poor subsistence returns and hunger, increased inter-group conflict (though evidence for warfare is absent in most of the Kurils), and emigration could have led to the rapid depopulation our paleodemography data reveal.

\section{Conclusion.}

In this paper we have explored an empirical model of Kuril Island demographic history based on archaeological radiocarbon frequencies. The data support a mid Holocene expansion into the remote central islands, followed by two periods of sustained growth punctuated by significant population declines. Successful settlement of and persistence in the remote islands would have required a combination of adept maritime technologies and skills as well as social networks at various scales. Those networks were needed for materials not locally available, marriage partners, information about natural and social resources and hazards, and friends to call on when conditions 
failed at home. We presented data that reveal different patterns of social networking in the Epi-Jomon and Okhotsk periods, along with environmental data on the effects of climate on local temperatures and precipitation.

While the data suggest that human populations responded in some degree to climate change, at least in the last 2000 years, we have argued that the human response to climate change was indirect at best. We believe that understanding the population variability in the Kurils demands an approach that considers the intersection of social and natural variables that together affect the vulnerability of small human populations. We suggest that the Jomon/Epi-Jomon emphasis on local adaptation and weak connections to the outside provided a remarkably successful strategy. They persisted in the archipelago for 3000 or more years. Their decline was gradual, probably related to a general decrease in the overall productivity of the Kuril ecosystem. We also argue that the Okhotsk-one way or another-were victims of the expanding East Asian World System that, while they did not directly depend on it, undermined the robustness of their more regional trade network. During the periods considered in this paper, the Kuril Islands probably remained outside most major World System interactions, but the growing incorporation of Hokkaido into that World System eroded the stability of network links between the Kurils and Hokkaido. These considerations raise the question of whether the settlement of the Kuril Islands by hunter-gatherers was ever possible without social links to Hokkaido and Kamchatka. Finally, although not discussed in this paper, the full incorporation of the Kuril Islands into the global World System with the rise of the sea otter trade in the eighteenth century and subsequent territorial competition between Japanese and Russian states completely transformed and ultimately ended the Ainu occupation of the Kurils (Walker, 2001).

We believe that there are lessons in this history for contemporary society. The hyper-connected world we live in today comes with its own advantages and vulnerabilities. Being connected gives us nearly instant access to information. Like the ancient settlers of the Kurils, this information helps us to navigate our world and avoid some pitfalls (or to deal with them, when we have to). By the same token, we are so deeply dependent on our complex and interconnected networks, that any loss of connectivity can create chaos and panic. The people who are most vulnerable are those with unequal or unreciprocated dependence on their network partners. The Jomon/EpiJomon appear to have interacted with more or less co-equal partners at low levels of intensity. Their exchange was based on reciprocation and minimal interdependence. The Okhotsk, by contrast were influenced by a growing economic World System that encouraged asymmetric relationships and created unprecedented vulnerability to the fluctuations of environment as well as the whims of markets, social developments, and epidemics beyond their control or even awareness. Chances for sustainability are improved - but not ensured over long enough time periods - with a healthy balance of self-sufficiency and a modest social network, with limited interdependence.

\section{Acknowledgments}


The research reported here was financially supported by the U.S. National Science Foundation (0508109; 1202879). Project administrative support came from the UW Center for Studies in Demography and Ecology (CSDE), with funding from a Eunice Kennedy Shriver National Institute of Child Health and Human Development (NICHD) research infrastructure grant, R24 HD042828. Additional support was provided by the University of Washington, Seattle, WA, USA; the Hokkaido University Museum (Sapporo, Japan); the Historical Museum of Hokkaido (Sapporo, Japan); the Sakhalin Regional Museum (Yuzhno-Sakhalinsk, Russia), and the Far East Branch of the Russian Academy of Sciences (IMGG: Yuzhno-Sakhalinsk, IVS: PetropavlovskKamchatskiy, NEISRI: Magadan, TIG: Vladivostok). This paper is the product of extensive and ongoing discussion with many people, and we especially wish to thank our international collaborators on the Kuril Biocomplexity Project and many others who provided insightful feedback and analytical support through the process, including the guest editors, Andrzej Weber and Peter Jordan and a very helpful anonymous reviewer. While we take full credit for any errors or omissions, we gratefully acknowledge a much larger team effort. 


\section{List of References}

Amano, T., 1979. Regional Differences in the Development of Okhotsk Culture. Northern Culture Research 12, 75-92. [In Japanese].

Amano, T., 2003. What is the Okhotsk culture? In: Nomura T, Utagawa H, (Eds.), EpiJomon and Okhotsk Culture, Sapporo, Hokkaido Sinbun-sha, p 110-133. [In Japanese.]

Amano, T., Akanuma, H., Kharinskiy, A.V., 2013. Study on the production region of iron goods and the roots of forging technology of the Okhotsk Culture. Hokkaido Univeristy Museum, Sapporo.

Amano, T., Vasilevsky, A.A. (Eds.), 2002. Okhotsk Culture Formation: Metamorphosis and Ending. Hokkaido University Museum, Sapporo.

Anderson, P., Lozhkin, A., Minyuk, P., Pakhomov, A., and Shamraev, V., 2007. Paleoecology and Paleoclimate Report for the Kuril Biocomplexity Project, Unpublished manuscript on file with Dr. Ben Fitzhugh, University of Washington, Seattle.

Anderson, P., Lozhkin, A., Minyuk, P., 2008. Paleoecology and Paleoclimate - Kuril Biocomplexity Project (Report submitted by the Kuril Biocomplexity Project). University of Washington.

Aston, W.G., 1972. Nihongi: Chronicles of Japan from the Earliest Times to AD 697. Tuttle, Rutland VT.

Attenbrow, V., Hiscock, P., 2015. Dates and demography: are radiometric dates a robust proxy for long-term prehistoric demographic change? Archaeology in Oceania, 50(S1), 30-36. http://dx.doi.org/10.1002/arco.5052

Ballenger, J.A.M., Mabry, J.B., 2011. Temporal frequency distributions of alluvium in the American Southwest: taphonomic, paleohydraulic, and demographic implications. Journal of Archaeological Science 38(6), 1314-1325. http://dx.doi.org/10.1016/j.jas.2011.01.007

Bandy, M. S., 2005. New World settlement evidence for a two-stage Neolithic demographic transition. Current Anthropology 46, S109-S115. http://dx.doi.org/10.1086/497665

Batchelor, J., 1901. The Ainu and their folk-lore. Religious Tract Society.

Batt, C.M., Pollard, A.M., 1996. Radiocarbon calibration and the peopling of North America. In: Orna, M.V. (Ed.), Archaeological Chemistry: Organic, Inorganic and Biocemical Analysis. American Chemical Society, Washington, D.C., pp. 415-433. http://dx.doi.org/10.1021/bk-1996-0625.ch030

Baxter, M.J., Beardah, C.C., Wright, R.V.S., 1997. Some archaeological applications of kernel density estimates. Journal of Archaeological Science 24, 347-354. http://dx.doi.org/10.1006/jasc. 1996.0119

Befu, H., Chard, C., 1964. A Prehistoric Maritime Culture of the Okhotsk Sea. American Antiquity 30, 1-18.

Bishop, R.L., Rands, R.L., Holley, G.R., 1982. Ceramic compositional analysis in archaeological perspective. Advances in archaeological method and theory 275330.

Boulanger, M.T., Lyman, R.L., 2014. Northeastern North American Pleistocene megafauna chronologically overlapped minimally with Paleoindians. Quaternary Science Reviews 85, 35-46. http://dx.doi.org/10.1016/j.quascirev.2013.11.024 
Brown, W.A., 2015. Through a filter, darkly: population size estimation, systematic error, and random error in radiocarbon-supported demographic temporal frequency analysis. Journal of Archaeological Science 53, 133-147.

Bulgakov, R., 1996. Reconstruction of Quaternary history of southern Kuril Islands. Journal of Coastal Research, 930-939.

Burkanov, V.N., Loughlin, T.R., 2005. Distribution and abundance of Steller sea lions, Eumetopias jubatus, on the Asian coast, 1720's-2005. Marine Fisheries Review 67, $1-62$.

Chamberlain, A., 2006. Demography in Archaeology. Cambridge University Press, Cambridge.

Chaput, M.A., Gajewski, K., 2015. Radiocarbon dates as estimates of ancient human population size. Anthropocene, in press. http://dx.doi.org/10.1016/j.ancene.2015.10.002

Chard, C., 1961. Kamchadal culture and its relationships in the Old and New Worlds. Society for American Archaeology, Madison Wis.

Chavez, F.P., Ryan, J., Lluch-Cota, S.E., Ñiquen, M., 2003. From anchovies to sardines and back: multidecadal change in the Pacific Ocean. Science 299, 217-221.

Cherry, J.F., 1981. Pattern and process in the earliest colonization of the Mediterranean islands. Proceedings of the Prehistoric Society 47, 41-68.

Collard, M., Edinborough, K., Shennan, S., Thomas, M.G., 2010. Radiocarbon evidence indicates that migrants introduced farming to Britain. Journal of Archaeological Science 37(4), 866-870. http://dx.doi.org/10.1016/j.jas.2009.11.016

Dean, J.S., 1978. Independent dating in archaeological analysis. Advances in Archaeological Method and Theory 1, 223-255. http://dx.doi.org/10.1016/B978-0-12003101-6.50013-5

Deryugin, V., 2008. On the definition of the term "Okhotsk Culture." Archaeology, Ethnology and Anthropology of Eurasia 33, 58-66.

Dikov, N.N., 2004. Early Cultures of Northeastern Asia. Translated by R.L. Bland. US Department of the Interior, National Park Service, Shared Beringian Heritage Program, Washington, D.C.

Dikova, T., 1983. South Kamchatka Archaeology in Connection with the Ainu Occupation Problem. Nauka, Moscow. (Russian)

Downey, S.S., Bocaege, E., Kerig, T., Edinborough, K., Shennan, S., 2014. The Neolithic Demographic Transition in Europe: correlation with juvenility index supports interpretation of the summed radiocarbon date probability distribution (SCDPD) as a valid demographic proxy. PLoS ONE 9(8).

http://dx.doi.org/10.1371/journal.pone.0105730

Etter, C., 1949. Ainu folklore; traditions and culture of the vanishing aborigines of Japan. Wilcox \& Follett Co., Chicago.

Farris, W.W., 1995. Population, Disease, and Land in Early Japan, 645-900. Council on East Asian Studies, Harvard University, Cambridge MA.

Fitzhugh, B., 2012. Hazards, Impacts and Resilience among Hunter-Gatherers of the Kuril Islands. In: Cooper, J., Sheets, P.D. (Eds.), Surviving Sudden Environmental Change: Answers from Archaeology, University Press of Colorado, Boulder, pp. 1942. 
Fitzhugh, B., in press. Origins and development of Arctic maritime adaptations in the western Subarctic. In, the Oxford Handbook on Arctic Archaeology, T.M. Friesen and O.K. Mason, eds. Oxford: Oxford University Press.

Fitzhugh, B., Shubin, V., Tezuka, K., Ishizuka, Y., Mandryk, C., 2002. Archaeology in the Kuril Islands: Advances in the Study of Human Paleobiogeography and Northwest Pacific Prehistory. Arctic Anthropology 39, 69-94.

Fitzhugh, B., Moore, S., Lockwood, C., Boone, C., 2004. Archaeological Paleobiogeography in the Russian Far East: The Kuril Islands and Sakhalin in Comparative Perspective. Asian Perspectives 43, 92-122.

Fitzhugh, B., Phillips, S.C., Gjesfeld, E., 2011. Modeling Variability in Hunter-Gatherer Information Networks: An Archaeological Case Study from the Kuril Islands. In, Whallon, R., Lovis, W., Hitchcock, R.K. (Eds.), Information and Its Role in HunterGatherer Bands, Ideas, Debates and Perspectives 5. Cotsen Institute of Archaeology Press, Los Angeles, pp. 85-115.

Fitzhugh, W.W., 1999. Ainu ethnicity: A history. In, W. Fitzhugh and Ch. Dubreuil, [Eds.], Ainu: Spirit of a Northern People. Smithsonian Institution Press, Washington DC, pp. 9-26.

Fitzhugh, W.W., Crowell, A., 1988. Crossroads of continents: cultures of Siberia and Alaska. Smithsonian Institution Press, Washington, D.C.

Fitzhugh, W.W., Dubreil, C. (Eds.), 1999. Ainu: Spirit of a Northern People. Smithsonian Institution Press, Washington DC.

Ganzei, K.S., Razzhigayeva, N.G., Rybin, A.V., 2010. Landscape structure change of Matua Island in the latter half of the 20th - beginning of the 21st centuries (Kuril Archipelago). Geography and Natural Resources 31, 257-263. doi:10.1016/j.gnr.2010.09.011

Gayo, E.M., Latorre, C., Santoro, C.M., 2015. Timing of occupation and regional settlement patterns revealed by time-series analyses of an archaeological radiocarbon database for the South-Central Andes (16 $\left.16^{\circ}-25^{\circ} \mathrm{S}\right)$. Quaternary International 356, 4-14. http://dx.doi.org/10.1016/j.quaint.2014.09.076

Gjesfjeld, E., 2014. Of Pots and People: Investigating Pottery Production and Social Networks in the Kuril Islands (Unpublished PhD Dissertation). University of Washington.

Gjesfjeld, E., 2015. Network Analysis of Archaeological Data from Hunter-Gatherers: Methodological Problems and Potential Solutions. Journal Of Archaeological Method And Theory 22, 182-205.

Gjesfjeld, E., Phillips, S.C., 2013. Evaluating adaptive network strategies with geochemical sourcing data: a case study from the Kuril Islands, in: Knappett, C. (Ed.), Network Analysis in Archaeology: New Approaches to Regional Interaction. Oxford University Press, pp. 281-305.

Halstead, P., O'Shea, J.M., 1989. Bad year economics: cultural responses to risk and uncertainty. Cambridge University Press, New York.

Hudson, M.J., 1999. Ruins of Identity: Ethnogenesis in the Japanese Islands. University of Hawai'i Press, Honolulu.

Hudson, M., 2004. The perverse realities of change: world system incorporation and the Okhotsk culture of Hokkaido. Journal of Anthropological Archaeology 23, 290. 
Ishizuka, Y., 2001. Volcanic Activity and recent tephras in the Kuril Islands: field result during the International Kuril island Project (IKIP) 2000. Report on file with the Ben Fitzhugh (Project PI), University of Washington.

Jones, M.C., Marron, J.S., Sheather, S.J., 1996. A brief survey of bandwidth selection for density estimation. Journal of the American Statistical Association 91(433), 401407. http://dx.doi.org/10.2307/2291420

Kawashima, T., 2013. Social change at the end of the Middle Jomon: A perspective from resilience theory. Documenta Praehistorica 40, 227-232.

Kelly, R.L., Surovell, T.A., Shuman, B.N., Smith, G.M., 2013. A continuous climatic impact on Holocene human population in the Rocky Mountains. Proceedings of the National Academy of Sciences 110(2), 443-447.

http://dx.doi.org/10.1073/pnas. 1201341110

Kennett, D.J., Stafford Jr., T.W., Southon, J., 2008. Standards of evidence and Paleoindian demographics. Proceedings of the National Academy of Science 105 (50), E107. http://dx.doi.org/10.1073/pnas.0808960106

Kirch, P.V., Rallu, J.-L. (Eds.), 2007. The Growth and Collapse of Pacific Island Societies: Archaeological and Demographic Perspectives. University of Hawai'i Press, Honolulu.

Krasheninnikov, S.P., 1972. Explorations of Kamchatka, North Pacific scimitar; report of a journey made to explore eastern Siberia in 1735-1741, by order of the Russian Imperial Government. Oregon Historical Society, Portland.

Kuzmin, Y.V., Jull, A.J.T., Jones, G.A., 1998. Early agriculture in Primorye, Russian Far East: New radiocarbon and pollen data from Late Neolithic sites. Journal of Archaeological Science 25, 813-816.

Kuzmin, Y.V., Yanshina, O.V., Fitzpatrick, S.M., Shubina, O.A., 2012. The Neolithic of the Kurile Islands (Russian Far East): Current State and Future Prospects. Journal of Island and Coastal Archaeology 7, 234-254.

Lechterbeck, J., Ediborough, K., Kerig, T., Fyfe, R., Roberts, N., Shennan, S., 2014. Is Neolithic land use correlated with demography? An evaluation of pollen-derived land cover and radiocarbon-inferred demographic change from Central Europe. The Holocene 24(10), 1297-1307. http://dx.doi.org/10.1177/0959683614540952

Leonov, A., 1990. The Sea of Okhotsk. National Technological Information Service, Springfield, VA.

Louderback, L.A., Grayson, D.K., Llobera, M., 2010. Middle-Holocene climates and human population densities in the Great Basin, western USA. The Holocene 21(2), 366-373. http://dx.doi.org/10.1177/0959683610374888

Lozhkin, A.V., Anderson, P.M., Goryachev, N.A., Minyuk, P.A., Pakhomov, A.Y., Solomatkina, T.B., Cherepanova, M.V., 2010. First Lake Record of Holocene Climate and Vegetation Change of the Northern Kuril Islands. Doklady Earth Sciences 430, 198-200.

Maclnnes, B., Fitzhugh, B., Holman, D., 2014. Controlling for landform age when determining the settlement history of the Kuril Islands. Geoarchaeology 29, 185-201. http://dx.doi.org/10.1002/gea.21473

Maclnnes, B.T., Pinegina, T.K., Bourgeois, J., Razhigaeva, N.G., Kaistrenko, V.M., Kravchunovskaya, E.A., 2009. Field survey and geological effects of the 15 
November 2006 Kuril tsunami in the middle Kuril Islands. Pure and Applied Geophysics 166, 9-36.

Manning, K., Timpson, A., 2014. The demographic response to Holocene climate change in the Sahara. Quaternary Science Reviews 101, 28-35.

http://dx.doi.org/10.1016/j.quascirev.2014.07.003

McGovern, T.H., Bigelow, G., Amorosi, T., Russell, D., 1988. Northern islands, human error, and environmental degradation: A view of social and ecological change in the medieval North Atlantic. Human Ecology 16, 225-270.

Nakagawa, M., Ishizuka, Y., Hasegawa, T., Baba, A., Kosugui, A., 2009. Preliminary Report on Volcanological Research of KBP 2007-2008 Cruise by Japanase Volcanology Group. Unpublished report on file with the Ben Fitzhugh (Project PI), University of Washington.

N.G.D.C, 2013. National Geophysical Data Center. NOAA/WDS Global Historical Tsunami Database at NGDC.

Nomura, S., Sugiura, S., 1995. Hokugen no Jōmon bunka: Chishima rettō ni okeru yōsō [The northern frontier of Jomon culture: aspects of the Kurils Islands]. Kikan Kōkogaku 50, 62-69.

Ohyi, H., 1975. The Okhotsk culture, a maritime culture of the southern Okhotsk Sea region., in: Fitzhugh, W. (Ed.), Prehistoric Maritime Adaptations of the Circumpolar Zone. Mouton, The Hague, pp. 123-158.

Okada, H., 1998. Maritime adaptations in northern Japan. Arctic anthropology 335-339.

Omoto, K., Takeishi, K., Nishida, S., Fukui, J., 2010. Calibrated 14C Ages of Jomon Sites, NE Japan, and Their Significance. Radiocarbon 52, 534.

Onishi, H., 2003. Residents of a Cultural Boundary Area:Lineage and Household Composition of the Tobinitai Culture in Northern Japan. Nihon Kokogaku(Journal of the Japanese Archaeological Association) 10, 157-177. doi:10.11215/nihonkokogaku1994.10.16_157

Ono, H., Amano, T., 2007. Cultural descent related to the formation and its development of Japan: the evidence of nonmetric cranial traits., in: Oguchi, M., Sawato, H. (Eds.), Formation and Metamorphosis of Ainu Culture. Iwata, Inc., Tokyo, pp. 171-201.

Peros, M.C., Munoz, S.E., Gajewski, K., Viau, A.E., 2010. Prehistoric demography of North America inferred from radiocarbon data. Journal of Archaeological Science 37, 656-664. http://dx.doi.org/10.1016/j.jas.2009.10.029

Pettitt, P.B., Davies, W., Gamble, C.S., Richards, M.B., 2003. Palaeolithic radiocarbon chronology: quantifying our confidence beyond two half-lives. Journal of Archaeological Science 30, 1685-1693. http://dx.doi.org/10.1016/S03054403(03)00070-0

Phillips, S.C., 2011. Networked Glass: Lithic Raw Material Consumption and Social Networks in the Kuril Islands. (Unpublished Dissertation). University of Washington, Seattle.

Phillips, S.C., Speakman, R.J., 2009. Initial source evaluation of archaeological obsidian from the Kuril Islands of the Russian Far East using portable XRF. Journal of Archaeological Science 36, 1256-1263.

Pietsch, T.W., Amaoka, K., Stevenson, D.E., MacDonald, E.L., Urbain, B.K., Lopez, J.A., 2001. Freshwater fishes of the Kuril Islands and adjacent regions. Species 
diversity: an international journal for taxonomy, systematics, speciation, biogeography, and life history research of animals 6, 133-164.

Pietsch, T.W., Bogatov, V.V., Amaoka, K., Zhuravlev, Y., Barkalov, V., 2003. Biodiversity and biogeography of the islands of the Kuril Archipelago. Journal of Biogeography 30, 1297-1310.

Preston, S.H., Heuveline, P., Guillot, M., 2001. Demography: Measuring and Modeling Population Processes. Blackwell Publishing, Malden, MA.

Razjigaeva, N.G., Ganzey, L.A., Belyanina, N.I., Grebennikova, T.A., Ganzey, K.S., 2008. Paleoenvironments and landscape history of the Minor Kuril Islands since the Late Glacial. Quaternary International 179, 83-89. doi:10.1016/j.quaint.2007.10.017

Razjigaeva, N.G., Ganzey, L.A., Arslanov, K.A., Grebennikova, T.A., Belyanina, N.I., Mokhova, L.M., 2011. Paleoenvironments of Kuril Islands in Late PleistoceneHolocene: climatic changes and volcanic eruption effects. Quaternary International 237, 4-14.

Razjigaeva, N.G., Ganzey, L.A., Grebennikova, T.A., Belyanina, N.I., Mokhova, L.M., Arslanov, K.A., Chernov, S.B., 2013. Holocene climatic changes and vegetation development in the Kuril Islands. Quaternary International 290-291, 126-138. doi:10.1016/j.quaint.2012.06.034

Rick, J.W., 1987. Dates as data: an examination of the Peruvian preceramic radiocarbon record. American Antiquity 55-73.

Reimer, P.J., Bard, E., Bayliss, A., Beck, J.W., Blackwell, P.G., Bronk Ramsey, C., Buck, C.E., Cheng, H., Edwards, R.L., Friedrich, M., Grootes, P.M., Guilderson, T.P., Haflidason, H., Hajdas, I., Hatté, C., Heaton, T.J., Hoffmann, D.L., Hogg, A.G., Hughen, K.A., Kaiser, K.F., Kromer, B., Manning, S.W., Niu, M., Reimer, R.W., Richards, D.A., Scott, E.M., Southon, J.R., Staff, R.A., Turney, C.S.M., van der Plicht, J., 2013. IntCal13 and Marine13 radiocarbon age calibration curves 0-50,000 years cal BP. Radiocarbon 55(4), 1869-1887. http://dx.doi.org/10.2458/azu_js_rc.55.16947

Rieth, T.M., Hunt, T.L., 2008. A radiocarbon chronology for Sāmoan prehistory. Journal of Archaeological Science 35, 1901-1927. http://dx.doi.org/10.1016/j.jas.2007.12.001

Rodionov, S.., Bond, N.A., Overland, J.E., 2007. The Aleutian Low, storm tracks, and winter climate variability in the Bering Sea. Deep Sea Research Part II: Topical Studies in Oceanography 54, 2560-2577.

Samarin, I.A., Shubina, O.A., 2007. Fortified settlements of the chasi type on Kunashir Island: Kurile Isles of the Russian Far East. North Pacific Prehistory 1, 163-190.

Samarin, I.A., Shubina, O.A., 2013. Monuments of History and Culture of the YuzhnoKuril County. Sakhalin Regional Museum, Yuzhno-Sakhalinsk.

Sato, T., Amano, T., Ono, H., Ishida, H., Kodera, H., Matsumura, H., Yoneda, M., Masuda, R., 2007. Origins and genetic features of the Okhotsk people, revealed by ancient mitochondrial DNA analysis. Journal of Human Genetics 52, 618-627.

Sato, T., Amano, T., Ono, H., Ishida, H., Kodera, H., Matsumura, H., Yoneda, M., Masuda, R., 2009. Mitochondrial DNA haplogrouping of the Okhotsk people based on analysis of ancient DNA: an intermediate of gene flow from the continental Sakhalin people to the Ainu. Anthropological Science 117, 171-180.

Schiffer, M.B., 1987. Formation Processes of the Archaeological Record. University of New Mexico Press, Albuquerque. 
Segawa, T., 2005. Ainu ekoshisutemu no kōkogaku [The archaeology of the Ainu ecosystem]. Hokkaidō Shuppan Kikaku Sentā, Sapporo.

Segawa, T., 2011. Ainu no sekai [The world of the Ainu]. Kōdansha, Tokyo.

Segawa, T., 2012. Koropokkuru to wa dare ka? Chūsei no Chishima rettō to Ainu densetsu [Who were the Koropokkukuru? Ainu Legends and the Medieval Kuril Islands]. Shintensha, Tokyo.

Shaw, Jennie D., 2008. Driftwood as a Resource: Modeling fuelwood acquisition strategies in the mid- to late Holocene Gulf of Alaska. Unpublished Ph.D. dissertation, University of Washington, Seattle.

Shaw, Jennie D., n.d. Results of charcoal analysis conducted for the Kuril Biocomplexity Project. Unpublished report for the Kuril Biocomplexity Project. 2010 (tDAR id: 391761) ; doi:10.6067/XCV8JH3N2P. (http://core.tdar.org//document/391761/jennie-deo-shaw-2010-results-of-charcoalanalysis-conducted-for-the-kuril-island-biocomplexity-project)

Sheather, S.J., 2004. Density estimation. Statistical Science 19(4), 588-597. http://dx.doi.org/10.1214/088342304000000297

Sheather, S. J., and Jones, M. C., 1991. A reliable data-based bandwidth selection method for kernel density estimation. Journal of the Royal Statistical Society B 53(3), 683-690. http://dx.doi.org/10.2307/2345597

Shennan, S., Edinborough, K., 2007. Prehistoric population history: from the Late Glacial to the Late Neolithic in Central and Northern Europe. Journal of Archaeological Science 34, 1339-1345.

Shennan, S., Downey, S.S., Timpson, A., Edinborough, K., Colledge, S., Kerig, T., Manning, K., Thomas, M.G., 2013. Regional population collapse followed initial agriculture booms in mid-Holocene Europe. Nature Communications 4. http://dx.doi.org/10.1038/ncomms3486

Shott, M.J., 1992. Radiocarbon dating as a probabilistic technique: the Childers site and Late Woodland occupation in the Ohio Valley. Am. Antiq. 57 (2), 202-230. http://dx.doi.org/10.2307/280728

Shubin, V.O., 1977. First non-ceramic artifacts from Sakhalin and Kuril Islands, in: Vasilevsky, R. (Ed.), Archaeological Investigations in the Sakhalin Region. Academy of Science USSR, DVNC, Vladivostok.

Shubin, V.O., 1994. Aleut in the Kuril Islands, in: Fitzhugh, W., Chaussonet, V. (Eds.), Anthropology of the North Pacific Rim. Smithsonian Instition Press, Washington DC, pp. 337-345.

Shubina, O.A., 1999. Yuzhno-Sakhalin. Stages of peopling of fortified settlement Belkamennaya-Chasi on southern Sakhalin. Bulletin of the Southern Sakhalin Regional Museum 6, 227-252.

Shubina, O.A., Samarin, I.A., 2009. Report on Archaeological Field Surveys in 2007 on Iturup and Kunashir Islands. Appendix in: Report of Archaeological Field Research in 2007, including Geological Descriptions of Archaeological Locales, by B Fitzhugh, S.C. Phillips, M. Etnier, S. Anderson, J. Taylor, M. Walsh, B.T. Maclnnes, and J. Bourgeois. (tDAR id: 376673); doi:10.6067/XCV8JQ109Q

Silverman, B. W., 1986. Density Estimation. Chapman and Hall, London.

Skalski, J.R., Ryding, K.E., Millspaugh, J.J., 2005. Wildlife Demography: Analysis of Sex, Age, and Count Data. Elsevier Academic Press, Amsterdam. 
Smale, J., 2014. End of Okhotsk? A Peer Polity Interaction approach to the interaction, exchange and decline of a Northeast-Asian maritime culture on Hokkaido, Japan.

M.A. Thesis, Leiden University. http://hdl.handle.net/1887/28236.

Snow, H.J., 1897. Notes on the Kuril Islands. London: John Murray.

Sonett, C.P., Finney, S.A., Berger, A., 1990. The spectrum of Radiocarbon. Philosophical Transactions of the Royal Society of London A 330, 413-426. http://dx.doi.org/10.1098/rsta.1990.0022

Stashenko, T.V., Gladyshev, S.A., 1977. The Ancient Monuments of the Kuril Islands, in: Vasilevsky, R. (Ed.), Archaeological Investigations in the Sakhalin Region. Academy of Science USSR, DVNC, Vladivostok.

Stephan, J.J., 1974. The Kuril Islands: Russo-Japanese Frontier in the Pacific. Clarendon Press, Oxford.

Surovell, T.A., Brantingham, P.J., 2007. A note on the use of temporal frequency distributions in studies of prehistoric demography. Journal of Archaeological Science 34, 1868-1877.

Surovell, T.A., Waguespack, N.M., 2008. How many elephant kills are 14 ? Clovis mammoth and mastodon kills in context. Quaternary International 191, 82-97. http://dx.doi.org/10.1016/j.quaint.2007.12.001

Surovell, T.A., Finley, J.B., Smith, G.M., Brantingham, P.J., Kelly, R., 2009. Correcting temporal frequency distributions for taphonomic bias. Journal of Archaeological Science 36, 1715-1724.

Suzuki, A., 2011. Smallpox and the epidemiological heritage of Modern Japan: towards a total history. Medical History 55:3150318.

Takamiya, H., Hudson, M.J., Yonenobu, H., Kurozumi, T., Toizumi, T., 2015. An extraordinary case in human history: prehistoric hunter-gatherer adaptation to the islands of the central Ryukyus (Amami and Okinawa archipelagos), Japan. The Holocene (DOI 10.1177/0959683615609752).

Takase, K., 2013. Chronology and age determination of pottery from the southern Kamchatka and northern Kuril Islands, Russia. Journal of the Graduate School of Letters, Hokkaido University 8, 35-61.

Tallavaara, M., Luoto, M., Korhonen, N., Järvinen, H., Seppä, H., 2015. Human population dynamics in Europe over the Last Glacial Maximum. Proceedings of the National Academy of Sciences 112(27), 8232-8237.

http://dx.doi.org/10.1073/pnas.1503784112

Tamura, S., 1999. Ainu language: features and relationships. In, Ainu: Spirit of a Northern People, W. Fitzhugh and Ch. Dubreuil, eds. Smithsonian Institution Press, Washington DC, pp.57-65

Tezuka, K., 2009. Ainu sea otter hunting from the perspective of Sino-Japanese trade. Senri Ethnological Studies 72, 117-131.

Tezuka, K., 2011. Ainu no Minzoku Kōkogaku [The Ethnoarchaeology of the Ainu]. Dōseisha, Tokyo.

Timpson, A., Colledge, S., Crema, E., Edinborough, K., Kerig, T., Manning, K., Thomas, M.G., Shennan, S., 2014. Reconstructing regional population fluctuations in the European Neolithic using radiocarbon dates: a new case-study using an improved method. Journal of Archaeological Science 52, 549-557.

http://dx.doi.org/10.1016/j.jas.2014.08.011 
Tokinaga, H., Xie, S.P., 2009. Ocean tidal cooling effect on summer sea fog over the Okhotsk Sea. Journal of Geophysical Research 114.

Torii, R., 1919. Études Archeéologiques et Ethnologiques: Les Aïnou des lles Kouriles. Journal of the College of Science, Imperial University of Tokyo 42, 1-336.

Trites, A.W., Miller, A.J., Maschner, H.D., Alexander, M.A., Bograd, S.J., Calder, J.A., Capotondi, A., Coyle, K.O., LORENZO, E.D., Finney, B.P., others, 2007. Bottom-up forcing and the decline of Steller sea lions (Eumetopias jubatus) in Alaska: assessing the ocean climate hypothesis. Fisheries Oceanography 16, 46-67.

Utagawa, H., 2008. Shiretoko no gaiyō [An outline of Shiretoko], in: Shiretoko Museum (Eds.), Shiretoko no Kōko [The Archaeology of Shiretoko]. Shari Board of Education, Shari, Hokkaido, pp. 12-21.

Vasilevsky, A.A., 2005. The Paradox of Okhotsk Culture: Farwell to a Great Legend, in: Movement in Medieval Northeast Asia: People, Material, Goods, Technology. Presented at the Vladivostok International Symposium, Vladivostok, pp. 67-76.

Vasilevsky, A., Shubina, O., 2006. Neolithic of the Sakhalin and Southern Kurile Islands, in: Nelson, S.M., Derevianko, A., Kuzmin, Y., Bland, R. (Eds.), Archaeology of the Russian Far East: Essays in Stone Age Prehistory, BAR International Series. Archaeopress, Oxford, England, pp. 151-166.

Walker, B.L., 2001. The Conquest of Ainu Lands: Ecology and Culture in Japanese Expansion, 1590-1800. University of California Press, Berkeley.

Wand, M.P., and Jones, M.C., 1995. Kernel Smoothing. Chapman and Hall, London.

Wang, C., Lu, H., Zhang, J., Gu, Z, He, K., 2014. Prehistoric demographic fluctuations in China inferred from radiocarbon data and their linkage with climate change over the past 50,000 years. Quaternary Science Reviews 98, 45-59. http://dx.doi.org/10.1016/j.quascirev.2014.05.015

Ward, G.K., Wilson, S.R., 1978. Procedures for comparing and combining radiocarbon age determinations: a critique. Archaeometry 20(1), 19-31. http://dx.doi.org/10.1111/j.1475-4754.1978.tb00208.x

Waters, M.R., Stafford Jr., T.W., 2007. Redefining the age of Clovis: implications for the peopling of the Americas. Science 315, 1122-1126. http://dx.doi.org/10.1126/science.1137166

Weninger, B., 1986. High-precision calibration of archaeological radiocarbon dates. Acta Interdisciplinaria Archaeologica 4, 11-53.

Wiessner, P.W., 1977. Hxaro: a regional system of reciprocity for reducing risk among the!Kung San (Unpublished Dissertation). University of Michigan, Ann Arbor, MI.

Williams, A.N., 2012. The use of summed radiocarbon probability distributions in archaeology: a review of methods. Journal of Archaeological Science 39, 578-589.

Williams, A.N., 2013. A new population curve for prehistoric Australia. Proceedings of the Royal Society B 280, 20130486. http://dx.doi.org/10.1098/rspb.2013.0486

Williams, A.N., Ulm, S., Cook, A.R., Langley, M.C., Collard, M., 2013. Human refugia in Australia during the Last Glacial Maximum and Terminal Pleistocene: a geospatial analysis of the 25-12 ka Australian archaeological record. Journal of Archaeological Science 40, 4612-4625. http://dx.doi.org/10.1016/j.jas.2013.06.015

Williams, A.N., Ulm, S., Turney, C.S.M., Rohde, D., White, G., 2015a. Holocene demographic changes and the emergence of complex societies in prehistoric 
Australia. PLoS ONE 10(6), e0128661. http://dx.doi.org/10.1371/journal.pone.0128661

Williams, A.N., Veth, P., Steffen, W., Ulm, S., Turney, C.S.M., Reeves, J.M., Phipps, S.J., Smith, M., 2015. A continental narrative: human settlement patterns and Australian climate change over the last 35,000 years. Quaternary Science Reviews 123, 91-112. http://dx.doi.org/10.1016/j.quascirev.2015.06.018

Yamada, G., 1999. The distribution of the archaeological sites and environmental human adaptation in the Kuril Islands, in: Peoples and Cultures in the Northern Islands. Proceedings of the 10th International Abashiri Symposium. Hokkaido Museum of Northern Peoples, Abashiri, pp. 1-18.

Yamaura, K., 1998. The Sea Mammal Hunting Cultures of the Ohhotsk Sea with Special Reference to Hokkaido Prehistory. Arctic Anthropology 35, 321-334.

Yamaura, K., Ushiro, H., 1999. Prehistoric Hokkaido and Ainu Origins, in: Fitzhugh, W., Dubreil, C. (Eds.), Ainu: Spirit of a Northern People. Smithsonian Institution Press, Washington DC, pp. 39-46.

Yanshina, O.V., Kuzmin, Y.V., 2010. The earliest evidence of human settlement in the Kurile Islands (Russian Far East): the Yankito site cluster, Iturup Island. Journal of Island \& Coastal Archaeology 5, 179-184.

Yanshina, O.V., Kuzmin, Y.V., Burr, G.S., 2009. Yankito, the oldest archaeological site cluster on the Kurile Islands (Russian Far East). Current Research in the Pleistocene 26, 30-33.

Zahid, H.J., Robinson, E., Kelly, R.L., 2015. Agriculture, population growth, and statistical analysis of the radiocarbon record. Proceedings of the National Academy of Sciences, in press. http://dx.doi.org/10.1073/pnas.1517650112 


\section{List of Figures}

Fig. 1: Map of Kuril Islands showing major islands and selected archaeological sites discussed in the text. Dashed lines indicate location of major straits that divide the islands into four biogeographic and analytical regions. The inset shows the location of the Kuril Islands in the Northeast Asia and Northwest Pacific. (Redrawn from a base-map by Adam Freeburg.)

Fig. 2: Map of the Drobnnye 1 archaeological site on Shiashkotan Island, showing house pits recorded and test units excavated in 2006 and 2007 by the Kuril Biocomplexity Project team.

Fig. 3: Summary of taxonomic identification of archaeological charcoal from Rasshua 1, Vodopadnaya 2, and Ainu Creek archaeological sites $(n=116)$. See text and Shaw (n.d.).

Fig. 4: A temporal frequency distribution (tfd) of summed archaeological radiocarbon probabilities from 364 Kuril archaeological dates. The summed probability distribution ( $s p d$; thin line) is derived from 253 independent records in which non-unique radiocarbon dates from the 364 have been pooled. A kernel density estimate (KDE; thick line) is plotted that smooths out calibration interference and random sampling error (See Supplementary materials). The top bar indicates relative temperature change based on palynological evidence (Razjigaeva et al. 2013). The bottom bar shows cultural historical period designation (Omoto et al., 2010). Large asterisks indicate caldera forming eruptions and small asterisks indicate major non-caldera eruptions. The first known time of occupation in each region is indicated on the graph by "S" (first occupation in the south), "C" (central, including both south-central and north central regions on the Fig. 1 map) and "N" (north). See Fig. 1 for regional divisions. Numbers on the graph correspond to major demographic trends enumerated in the text.

Fig. 5: (a) Microblades from Trudnaya 1 site on southern Paramushir; (b) obsidian biface from Savushkino 2 site on northern Paramushir.

Fig. 6: Select sherds representing diagnostic pottery decoration for the (a) Early Epi-Jomon from Rasshua (FS\#3990, SRM\#8077-41), (b) the Late Epi-Jomon from Iturup (FS\#47, SRM\#7867-167) and the (c) Middle or Late Okhotsk from Kharimkotan (FS\#776). All sherds are currently curated at the Sakhalin Regional Museum (SRM).

\section{List of Tables:}

Table 1: Distribution of radiocarbon dates from through Kuril Islands. Dominant sources refer to sites receiving more extensive archaeological sampling and disproportionate dating. The southern and northernmost islands have the least coverage in the KBP radiocarbon database because of the decision to focus efforts in the more remote, central sections, where less archaeological attention had been directed by previous research efforts.

Table 2: Radiocarbon dates from the Kuril Biocomplexity Project (KBP) and International Kuril Island Project (IKIP). Table includes all dates used in the paleodemography model plus a small number of additional dates that were excluded from that analysis (see text for reasons).

Supplement: Summed probability distribution and kernel density estimate calculation. 
Table 1:

\begin{tabular}{|r|r|l|}
\hline \multicolumn{1}{|l|}{ Kuril Islands } & Date Frequency & $\begin{array}{l}\text { Dominant } \\
\text { sources }\end{array}$ \\
\hline South & $\mathbf{8 9}$ & \\
\hline Iturup & 13 & \\
\hline Kunashir & 14 & \\
\hline Urup & 4 & \\
\hline South Center & 58 & Ainu Creek 1 \\
\hline Matua & 143 & \\
\hline Rasshua & 7 & \\
\hline Simushir & 66 & Rasshua 1 \\
\hline Ushishir & 58 & Vodopadnaya 2 \\
\hline North Central & 12 & \\
\hline Chirinkotan & 116 & \\
\hline Ekarma & 5 & \\
\hline Kharimkotan & 27 & Ekarma 1 and 2 \\
\hline Makanrushi & 5 & \\
\hline Onekotan & 12 & \\
\hline Shiashkotan & 11 & \\
\hline North Kurils & 56 & Drobnyye 1 \\
\hline Paramushir & $\mathbf{3 2}$ & \\
\hline Shumshu & 14 & \\
\hline Grand Total & 18 & \\
\hline & $\mathbf{3 8 0}$ & \\
\hline & & \\
\hline & & \\
\hline
\end{tabular}

Table 2: [See separate file] 


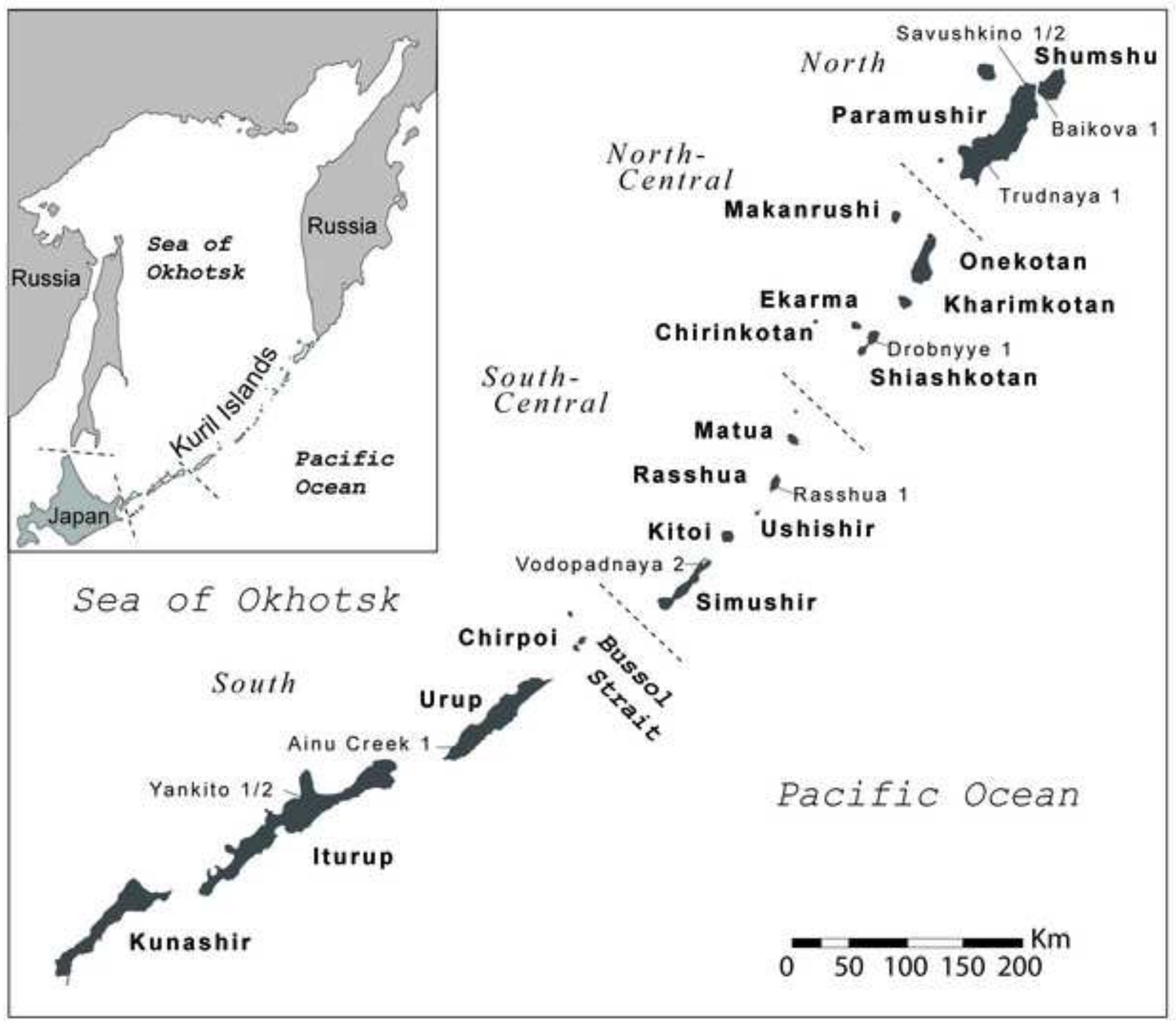




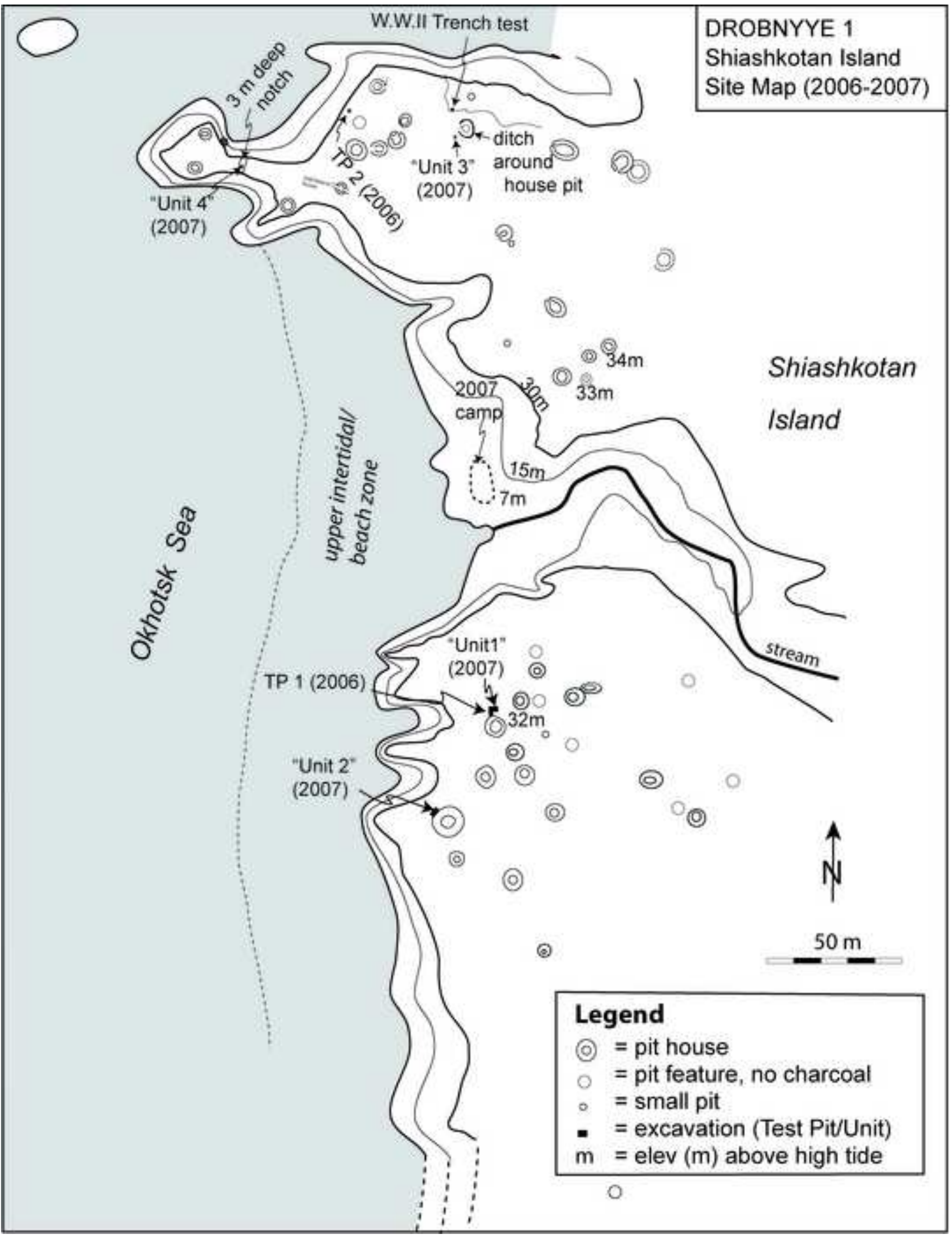




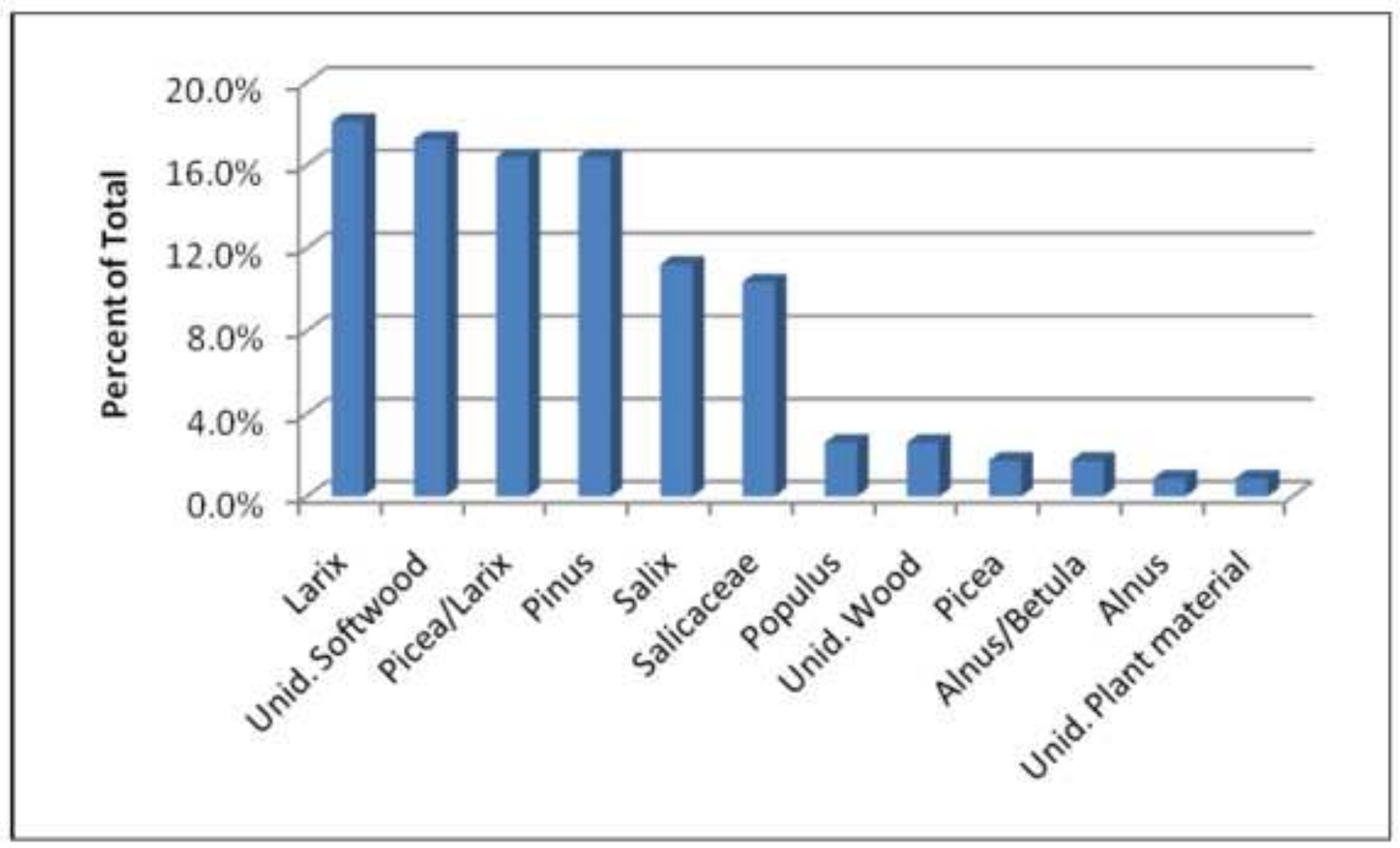




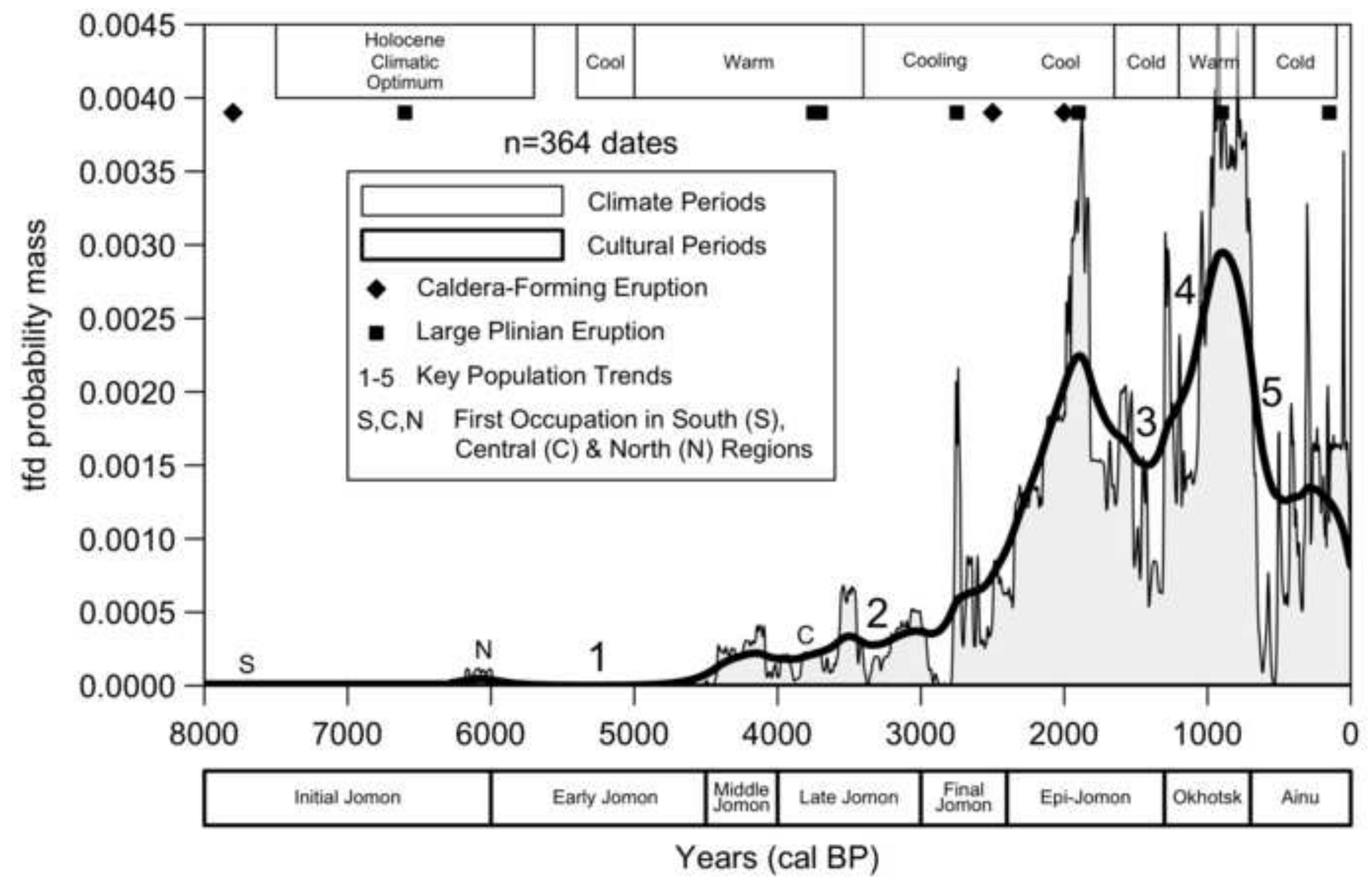




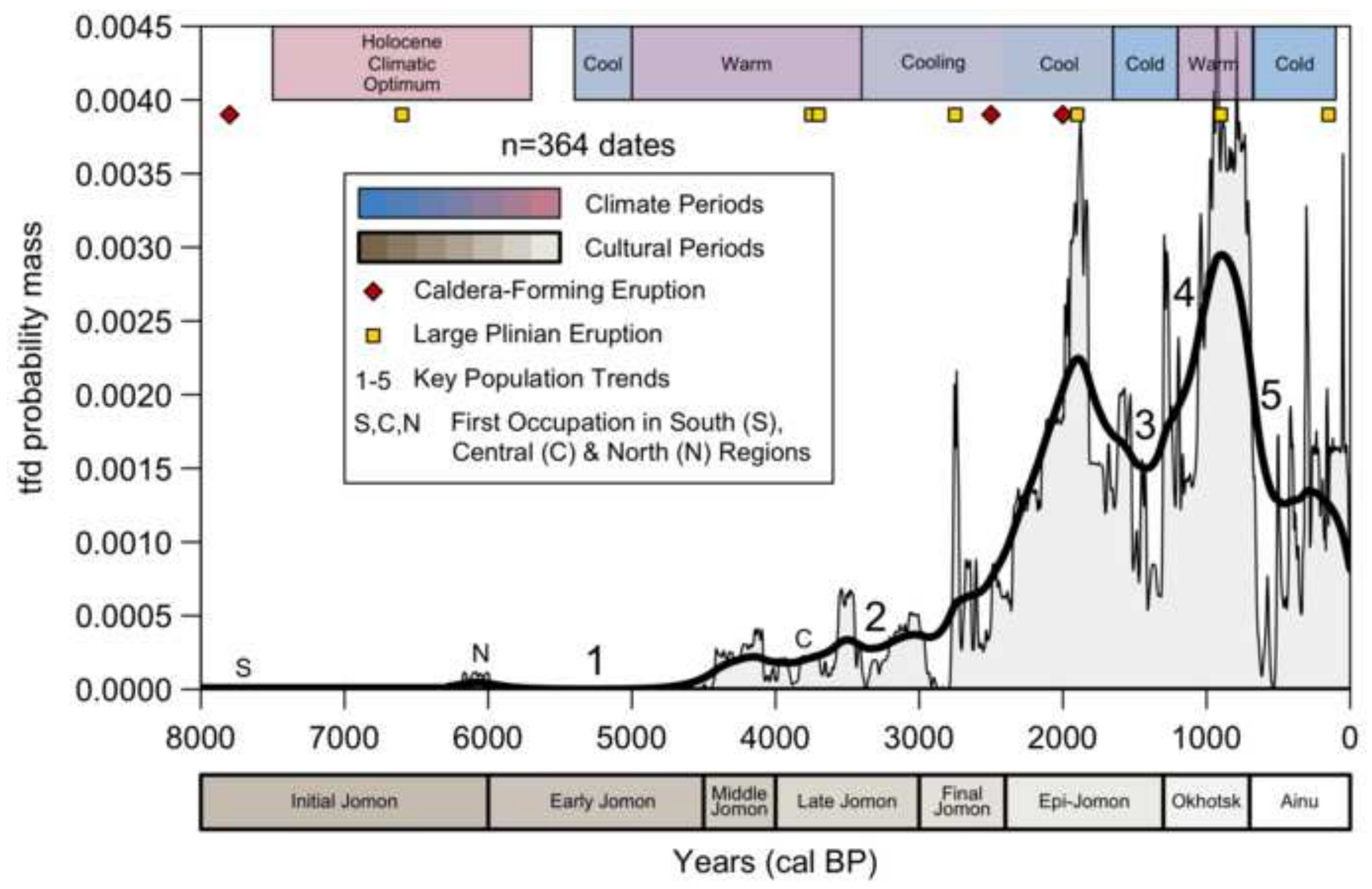


a

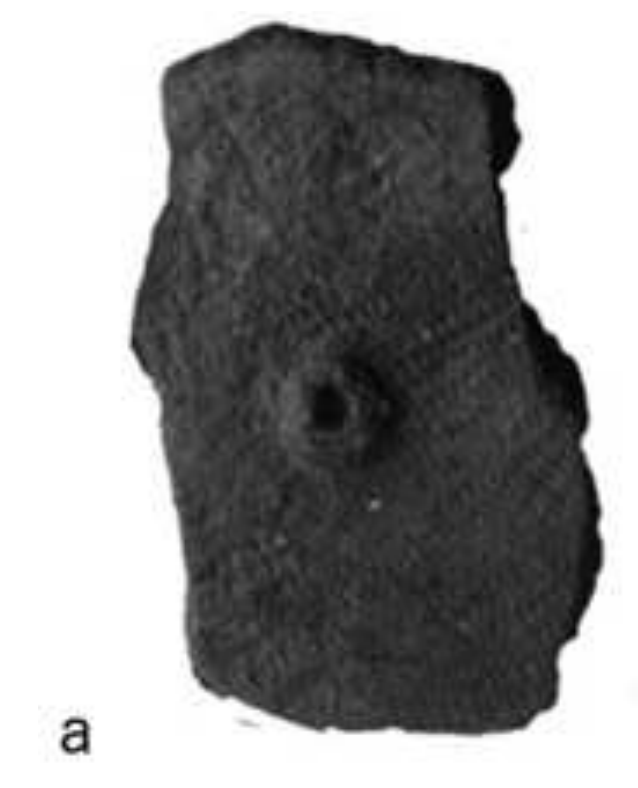

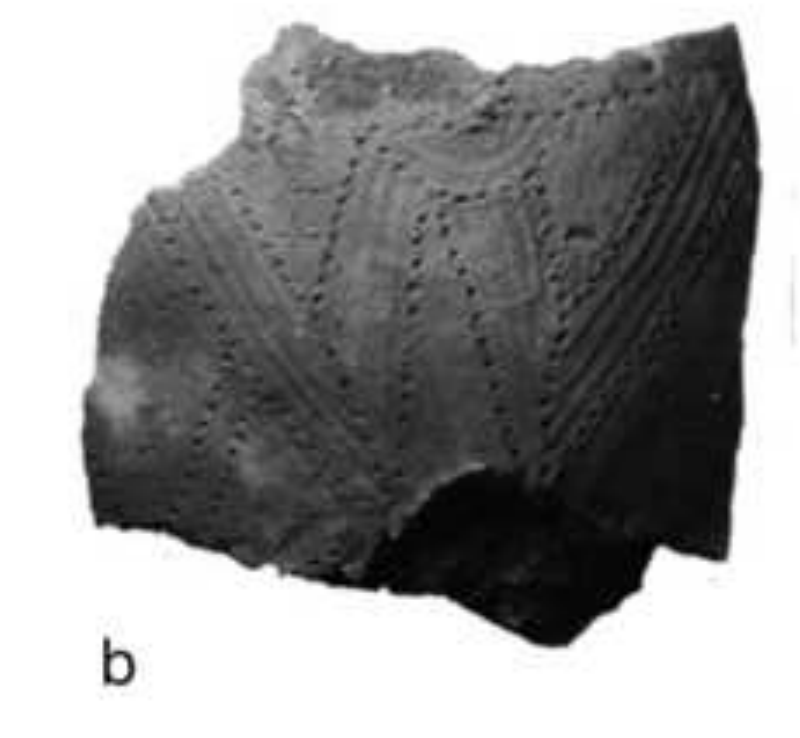

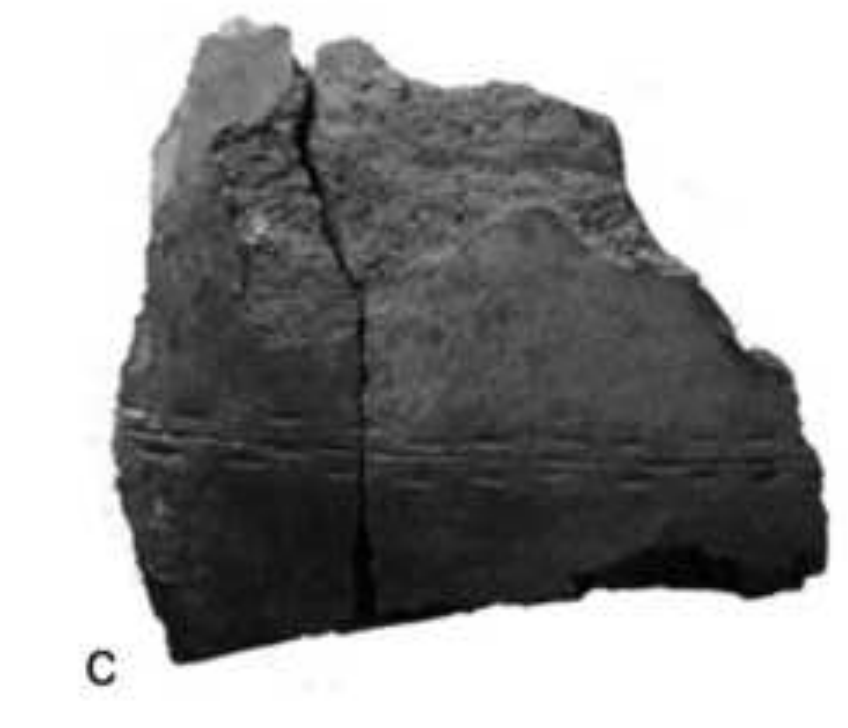

b

$$
\text { . }
$$


Table 2: Radiocarbon dates from the Kuril Biocomplexity Project (KBP) and International Kuril Island Project (IKIP). Table includes all dates used in the paleodemography model plus a small number of additional dates that were excluded from that analysis (see text for reasons).

\begin{tabular}{|c|c|c|c|c|c|c|c|c|c|c|}
\hline $\begin{array}{l}\text { Island } \\
\text { number }\end{array}$ & Section & Island & Site Name & Context2 & Material3 & $\begin{array}{l}\text { Catalog } \\
\#\end{array}$ & Lab \# & 14C age & $\begin{array}{l}\text { "95.4\% } \\
\text { Credible } \\
\text { Interval }\end{array}$ & \\
\hline $\begin{array}{l}\text { (cal } \\
\text { BP)4" }\end{array}$ & $\begin{array}{l}\text { Primary } \\
\text { IKIP/KBP } \\
\text { source6 }\end{array}$ & & & & & & & & & \\
\hline 1 & A-South & Kunashir & Rikorda 1 & $\begin{array}{l}\text { Test Pit 1, Level 1, } 0 \text { - } \\
28 \mathrm{cmbs}\end{array}$ & $\mathrm{Ch}$ & $\begin{array}{l}\text { KBP } \\
0107\end{array}$ & $\begin{array}{l}\text { OS- } \\
58975\end{array}$ & $2250 \pm 25$ & $\begin{array}{l}2341- \\
2158\end{array}$ & C \\
\hline 1 & A-South & Kunashir & Rikorda 1 & Test Pit 1, Level 2 & $\mathrm{Ch}$ & $\begin{array}{l}\text { KBP } \\
0115\end{array}$ & $\begin{array}{l}\text { OS- } \\
58967\end{array}$ & $2210 \pm 30$ & $\begin{array}{l}2320- \\
2148\end{array}$ & D \\
\hline 1 & A-South & Kunashir & $\begin{array}{l}\text { Serebryanoe } \\
2\end{array}$ & $\begin{array}{l}\text { Erosion face: } 35 \mathrm{cmbs}, 5 \mathrm{~cm} \\
\text { below Okhotsk pottery, } 15 \\
\mathrm{~cm} \text { above Epi-Jomon } \\
\text { pottery. Kun07-2 (Shubina } \\
\text { and Samarin Survey) }\end{array}$ & $\mathrm{Ch}$ & $\begin{array}{l}\text { KBP } \\
2635\end{array}$ & $\begin{array}{l}\text { OS- } \\
67411\end{array}$ & $2440 \pm 30$ & $\begin{array}{l}2700- \\
2357\end{array}$ & $E$ \\
\hline 1 & A-South & Kunashir & $\begin{array}{l}\text { Serebryanoe } \\
2\end{array}$ & $\begin{array}{l}\text { Erosion face: } 50-60 \mathrm{cmbs} \\
\text { associated with Epi-Jomon } \\
\text { pottery. Kun07-1 (Shubina } \\
\text { and Samarin Survey) }\end{array}$ & $\mathrm{Ch}$ & $\begin{array}{l}\text { KBP } \\
2634\end{array}$ & $\begin{array}{l}\text { OS- } \\
67403\end{array}$ & >Modern & $n / a$ & $E$ \\
\hline 2 & A-South & Iturup & Berezovka 1 & $\begin{array}{l}\text { Erosion face, Profile } 1, \\
\text { Level } 2 \text {, hearth feature }\end{array}$ & $\mathrm{Ch}$ & $\begin{array}{l}\text { KBP } \\
0059\end{array}$ & $\begin{array}{l}\text { OS- } \\
93589\end{array}$ & $3290 \pm 25$ & \begin{tabular}{|l}
$3572-$ \\
3456 \\
\end{tabular} & $E$ \\
\hline 2 & A-South & Iturup & Berezovka 1 & $\begin{array}{l}\text { Erosion face, Profile } 2, \\
\text { Level } 11, \text { charcoal sample } \\
\# 4, \text { from south end of level }\end{array}$ & $\mathrm{Ch}$ & $\begin{array}{l}\text { KBP } \\
0083\end{array}$ & $\begin{array}{l}\text { OS- } \\
58748\end{array}$ & $2300 \pm 30$ & $\begin{array}{l}2356- \\
2183\end{array}$ & C \\
\hline 2 & A-South & Iturup & Berezovka 1 & $\begin{array}{l}\text { Erosion face, Profile } 2,10 \\
\mathrm{~cm} \text { above hearth, charcoal } \\
\text { sample \#5 }\end{array}$ & $\mathrm{Ch}$ & $\begin{array}{l}\text { KBP } \\
0084\end{array}$ & $\begin{array}{l}\text { OS- } \\
93593\end{array}$ & $2110 \pm 25$ & $\begin{array}{l}2146- \\
2003\end{array}$ & $E$ \\
\hline 2 & A-South & Iturup & Berezovka 1 & $\begin{array}{l}\text { Erosion face, Profile } 2, \\
\text { Level } 9 \mathrm{~A} \text {, charcoal sample }\end{array}$ & $\mathrm{Ch}$ & $\begin{array}{l}\text { KBP } \\
0082\end{array}$ & \begin{tabular}{|l|} 
OS- \\
93592 \\
\end{tabular} & $2080 \pm 35$ & \begin{tabular}{|l}
$2144-$ \\
1950 \\
\end{tabular} & $E$ \\
\hline
\end{tabular}




\begin{tabular}{|c|c|c|c|c|c|c|c|c|c|c|}
\hline & & & & $\# 3$, from north end of level & & & & & & \\
\hline 2 & A-South & Iturup & Berezovka 1 & $\begin{array}{l}\text { Erosion face, Profile } 2,30- \\
40 \mathrm{~cm} \text { above hearth, } \\
\text { charcoal sample \#1 }\end{array}$ & $\mathrm{Ch}$ & $\begin{array}{l}\text { KBP } \\
0080\end{array}$ & $\begin{array}{l}\text { OS- } \\
93590\end{array}$ & $2070 \pm 30$ & $\begin{array}{l}2123- \\
1950\end{array}$ & $E$ \\
\hline 2 & A-South & Iturup & Berezovka 1 & $\begin{array}{l}\text { Erosion face, Profile } 2, \\
\text { Level 9B, charcoal sample } \\
\# 2, \text { north end of level }\end{array}$ & $\mathrm{Ch}$ & $\begin{array}{l}\text { KBP } \\
0081\end{array}$ & $\begin{array}{l}\text { OS- } \\
93591\end{array}$ & $2030 \pm 30$ & $\begin{array}{l}2105- \\
1898\end{array}$ & $E$ \\
\hline 2 & A-South & Iturup & Glush & $\begin{array}{l}\text { Test Pit } 1 \text { (erosion section), } \\
\text { cultural layer, } 56-80 \mathrm{cmbs} \text { - } \\
\text { two layers mixed }\end{array}$ & $\mathrm{Ch}$ & $\begin{array}{l}\text { KBP } \\
0595\end{array}$ & $\begin{array}{l}\text { OS- } \\
93602\end{array}$ & $3640 \pm 25$ & $\begin{array}{l}4079- \\
3875\end{array}$ & $E$ \\
\hline 2 & A-South & Iturup & Kasatka Bay 1 & $\begin{array}{l}\text { Erosion face, } 50-60 \mathrm{~cm} \text {, } \\
\text { associated with Middle } \\
\text { Jomon pottery, basalt and } \\
\text { obsidian: Itur07-2 (Shubina } \\
\text { and Samarin Survey) }\end{array}$ & $\mathrm{Ch}$ & $\begin{array}{l}\text { KBP } \\
2637\end{array}$ & $\begin{array}{l}\text { OS- } \\
67417\end{array}$ & $3880 \pm 30$ & $\begin{array}{l}4416- \\
4185\end{array}$ & C \\
\hline 2 & A-South & Iturup & Olya 1 & Test Pit 2, $94 \mathrm{cmbs}$ & $\mathrm{Ch}$ & $\begin{array}{l}\text { KBP } \\
0143\end{array}$ & $\begin{array}{l}\text { OS- } \\
93595\end{array}$ & $3820 \pm 25$ & $\begin{array}{l}4350- \\
4096\end{array}$ & $E$ \\
\hline 2 & A-South & Iturup & Olya 1 & $\begin{array}{l}\text { Test Pit 4, bottom cultural } \\
\text { layer, Epi-Jomon }\end{array}$ & $\mathrm{Ch}$ & $\begin{array}{l}\text { KBP } \\
0139\end{array}$ & $\begin{array}{l}\text { OS- } \\
93594\end{array}$ & $2990 \pm 30$ & $\begin{array}{l}3323- \\
3067\end{array}$ & $E$ \\
\hline 2 & A-South & Iturup & Olya 1 & Test Pit 3, Level 5 & $\mathrm{Ch}$ & $\begin{array}{l}\text { KBP } \\
0152 \\
\end{array}$ & $\begin{array}{l}\text { OS- } \\
93597\end{array}$ & $1170 \pm 35$ & $1180-981$ & $E$ \\
\hline 2 & A-South & Iturup & Olya 1 & $\begin{array}{l}\text { Test Pit } 4,10 \mathrm{cmbs} \text {, in root } \\
\text { matt with Okhotsk pottery }\end{array}$ & $\mathrm{Ch}$ & $\begin{array}{l}\text { KBP } \\
0144\end{array}$ & $\begin{array}{l}\text { OS- } \\
93596\end{array}$ & $1000 \pm 25$ & $964-802$ & $E$ \\
\hline 2 & A-South & Iturup & Rybaki 1 & $\begin{array}{l}\text { Modern trench exposure: } \\
\text { from cultural zone } 40-90 \\
\mathrm{cmbs} \text {, with Middle Jomon } \\
\text { pot sherd at } 40 \mathrm{cmbs} \text { : } \\
\text { Itur07-1 (Shubina and } \\
\text { Samarin Survey) }\end{array}$ & $\mathrm{Ch}$ & $\begin{array}{l}\text { KBP } \\
2636\end{array}$ & $\begin{array}{l}\text { OS- } \\
67412\end{array}$ & $3930 \pm 30$ & $\begin{array}{l}4507- \\
4249\end{array}$ & C \\
\hline 2 & A-South & Iturup & Tikhaya 1 & $\begin{array}{l}\text { "Test Pit 2", bark sample } \\
\text { from } 80 \mathrm{cmbs}\end{array}$ & WB & $\begin{array}{l}\text { KBP } \\
0172\end{array}$ & $\begin{array}{l}\text { OS- } \\
93598\end{array}$ & $1170 \pm 25$ & $1179-999$ & C \\
\hline 3 & A-South & Urup & Ainu Creek 1 & $\begin{array}{l}\text { Test Pit 4, Level 6, } 110 \text { - } \\
128 \mathrm{~cm}\end{array}$ & $\mathrm{Ch}$ & $\begin{array}{l}\text { KBP } \\
0386 \\
\end{array}$ & $\begin{array}{l}\text { OS- } \\
59522\end{array}$ & $3230 \pm 30$ & $\begin{array}{l}3557- \\
3381\end{array}$ & C \\
\hline 3 & A-South & Urup & Ainu Creek 1 & Test Pit 5, Profile 2, 210- & $\mathrm{Ch}$ & KBP & OS- & $2610 \pm 25$ & $2765-$ & $E$ \\
\hline
\end{tabular}




\begin{tabular}{|c|c|c|c|c|c|c|c|c|c|c|}
\hline & & & & $220 \mathrm{cmbs}$ & & 0538 & 59345 & & 2725 & \\
\hline 3 & A-South & Urup & Ainu Creek 1 & $\begin{array}{l}\text { Test Pit 5, Profile 2, } \\
\text { charcoal and bone layer, } \\
242-250 \mathrm{cmbs}\end{array}$ & $\mathrm{Ch}$ & $\begin{array}{l}\text { KBP } \\
0510\end{array}$ & $\begin{array}{l}\text { OS- } \\
59344\end{array}$ & $2550 \pm 25$ & $\begin{array}{l}2750- \\
2504\end{array}$ & $E$ \\
\hline 3 & A-South & Urup & Ainu Creek 1 & $\begin{array}{l}\text { Test Pit 2, Level 3, 52cmbs, } \\
\text { 36E 35N }\end{array}$ & $\mathrm{Ch}$ & $\begin{array}{l}\text { KBP } \\
0323\end{array}$ & $\begin{array}{l}\text { OS- } \\
59348\end{array}$ & $2540 \pm 30$ & $\begin{array}{l}2748- \\
2496\end{array}$ & $D$ \\
\hline 3 & A-South & Urup & Ainu Creek 1 & Unit A1, Level 3, $85 \mathrm{cmbd}$ & $\mathrm{Ch}^{*}$ & $\begin{array}{l}\text { KBP } \\
2361\end{array}$ & $\begin{array}{l}\text { OS- } \\
67620\end{array}$ & $2540 \pm 30$ & $\begin{array}{l}2748- \\
2496\end{array}$ & $\mathrm{D}$ \\
\hline 3 & A-South & Urup & Ainu Creek 1 & $\begin{array}{l}\text { Unit A1, Level 3, Epi-Jomon } \\
\text { level }\end{array}$ & $\mathrm{Ch}^{*}$ & $\begin{array}{l}\text { KBP } \\
2584 \mathrm{c}\end{array}$ & $\begin{array}{l}\text { OS- } \\
67623\end{array}$ & $2510 \pm 30$ & $\begin{array}{l}2740- \\
2489\end{array}$ & $E$ \\
\hline 3 & A-South & Urup & Ainu Creek 1 & $\begin{array}{l}\text { Test Pit 5, Profile 2, } 200 \\
\mathrm{cmbs}\end{array}$ & $\mathrm{Ch}$ & $\begin{array}{l}\text { KBP } \\
0531\end{array}$ & $\begin{array}{l}\text { OS- } \\
95615\end{array}$ & $2490 \pm 35$ & $\begin{array}{l}2737- \\
2435\end{array}$ & $E$ \\
\hline 3 & A-South & Urup & Ainu Creek 1 & $\begin{array}{l}\text { Unit A1, Level 3, Epi-Jomon } \\
\text { level }\end{array}$ & $\mathrm{Ch}^{*}$ & $\begin{array}{l}\text { KBP } \\
2584 b\end{array}$ & $\begin{array}{l}\text { OS- } \\
67644\end{array}$ & $2490 \pm 35$ & $\begin{array}{l}2737- \\
2435\end{array}$ & $E$ \\
\hline 3 & A-South & Urup & Ainu Creek 1 & $\begin{array}{l}\text { Test Pit 5, Profile 2, +/-205 } \\
\text { cmbs, Epi-Jomon layer }\end{array}$ & $\mathrm{Ch}$ & $\begin{array}{ll}\text { KBP } \\
0534\end{array}$ & $\begin{array}{l}\text { OS- } \\
98017\end{array}$ & $2460 \pm 25$ & $\begin{array}{l}2705- \\
2379\end{array}$ & $E$ \\
\hline 3 & A-South & Urup & Ainu Creek 1 & Unit A3, Level 2, $45 \mathrm{cmbd}$ & $\mathrm{Ch}^{*}$ & $\begin{array}{l}\text { KBP } \\
2046\end{array}$ & $\begin{array}{l}\text { OS- } \\
98019\end{array}$ & $2440 \pm 20$ & $\begin{array}{l}2697- \\
2358\end{array}$ & $E$ \\
\hline 3 & A-South & Urup & Ainu Creek 1 & $\begin{array}{l}\text { Test Pit 5, Profile 2, 260- } \\
270 \mathrm{cmbs} \text {, basal black layer }\end{array}$ & $\mathrm{Ch}$ & $\begin{array}{l}\text { KBP } \\
0507\end{array}$ & $\begin{array}{l}\text { OS- } \\
59376\end{array}$ & $2430 \pm 30$ & $\begin{array}{l}2699- \\
2354\end{array}$ & $E$ \\
\hline 3 & A-South & Urup & Ainu Creek 1 & $\begin{array}{l}\text { Unit B3, Level 3, } 60 \mathrm{cmbd} \text {, } \\
\text { near A3 in west section of } \\
\text { B3 }\end{array}$ & $\mathrm{Ch}^{*}$ & $\begin{array}{l}\text { KBP } \\
2281\end{array}$ & $\begin{array}{l}\text { OS- } \\
98021\end{array}$ & $2430 \pm 30$ & $\begin{array}{l}2699- \\
2354\end{array}$ & $E$ \\
\hline 3 & A-South & Urup & Ainu Creek 1 & Test Pit 4, Level 7, 133cmbs & $\mathrm{Ch}$ & $\begin{array}{l}\text { KBP } \\
0391\end{array}$ & $\begin{array}{l}\text { OS- } \\
59342\end{array}$ & $2410 \pm 30$ & $\begin{array}{l}2688- \\
2350\end{array}$ & $\mathrm{D}$ \\
\hline 3 & A-South & Urup & Ainu Creek 1 & Unit A1, Level 3, $65 \mathrm{cmbd}$ & Ch* & $\begin{array}{l}\text { KBP } \\
2663\end{array}$ & $\begin{array}{l}\text { OS- } \\
67630\end{array}$ & $2390 \pm 35$ & $\begin{array}{l}2683- \\
2343\end{array}$ & $\mathrm{E}$ \\
\hline 3 & A-South & Urup & Ainu Creek 1 & $\begin{array}{l}\text { Unit A1, Level 2, directly on } \\
\text { top of Level } 3\end{array}$ & $\mathrm{Ch}^{*}$ & $\begin{array}{l}\text { KBP } \\
2286\end{array}$ & $\begin{array}{l}\text { OS- } \\
67627\end{array}$ & $2350 \pm 30$ & $\begin{array}{l}2464- \\
2324\end{array}$ & $\mathrm{E}$ \\
\hline 3 & A-South & Urup & Ainu Creek 1 & $\begin{array}{l}\text { Unit A1, Level 3, Epi-Jomon } \\
\text { level }\end{array}$ & $\mathrm{Ch}^{*}$ & $\begin{array}{l}\text { KBP } \\
2584 a\end{array}$ & $\begin{array}{l}\text { OS- } \\
67643\end{array}$ & $2310 \pm 30$ & $\begin{array}{l}2360- \\
2184\end{array}$ & $\mathrm{E}$ \\
\hline 3 & A-South & Urup & Ainu Creek 1 & $\begin{array}{l}\text { Unit A1, Level 2, from } \\
\text { under dolphin skull }\end{array}$ & $\mathrm{Ch}^{*}$ & $\begin{array}{l}\text { KBP } \\
2285\end{array}$ & $\begin{array}{l}\text { OS- } \\
67619\end{array}$ & $2300 \pm 30$ & $\begin{array}{l}2356- \\
2183\end{array}$ & $\mathrm{E}$ \\
\hline 3 & A-South & Urup & Ainu Creek 1 & Unit B1, Level 2, 18-20 & $\mathrm{Ch}^{*}$ & KBP & OS- & $2290 \pm 30$ & $2354-$ & $\mathrm{E}$ \\
\hline
\end{tabular}




\begin{tabular}{|c|c|c|c|c|c|c|c|c|c|c|}
\hline & & & & cmbd, fire pit area & & $2359 a$ & 98020 & & 2180 & \\
\hline 3 & A-South & Urup & Ainu Creek 1 & $\begin{array}{l}\text { Unit B2, Level 2, } 25 \mathrm{cmbd} \\
\text { (with ceramics) }\end{array}$ & $\mathrm{Ch}^{*}$ & $\begin{array}{l}\text { KBP } \\
2044\end{array}$ & $\begin{array}{l}\text { OS- } \\
98018\end{array}$ & $2190 \pm 20$ & $\begin{array}{l}2309- \\
2142\end{array}$ & $E$ \\
\hline 3 & A-South & Urup & Ainu Creek 1 & $\begin{array}{l}\text { Test Pit 5, Profile 2, } 192 \\
\text { cmbs, Epi-Jomon layer }\end{array}$ & $\mathrm{Ch}$ & $\begin{array}{l}\text { KBP } \\
0537\end{array}$ & $\begin{array}{l}\text { OS- } \\
59377\end{array}$ & $2170 \pm 30$ & $\begin{array}{l}2309- \\
2065\end{array}$ & $E$ \\
\hline 3 & A-South & Urup & Ainu Creek 1 & $\begin{array}{l}\text { Test Pit 5, 115-125 cmbs, } \\
\text { fish bone and charcoal } \\
\text { stratum, above 'Okhotsk' } \\
\text { layer }\end{array}$ & $\mathrm{Ch}$ & $\begin{array}{l}\text { KBP } \\
0444\end{array}$ & $\begin{array}{l}\text { OS- } \\
59375\end{array}$ & $2050 \pm 35$ & $\begin{array}{l}2120- \\
1925\end{array}$ & $E$ \\
\hline 3 & A-South & Urup & Ainu Creek 1 & $\begin{array}{l}\text { Test Pit 5, Profile 2, } 60 \text { - } \\
80 \mathrm{cmbs}\end{array}$ & Ch & $\begin{array}{l}\text { KBP } \\
0443\end{array}$ & $\begin{array}{l}\text { OS- } \\
59795\end{array}$ & $2010 \pm 80$ & $\begin{array}{l}2296- \\
1741\end{array}$ & $E$ \\
\hline 3 & A-South & Urup & Ainu Creek 1 & $\begin{array}{l}\text { Test Pit 5, 150-160 cmbs, } \\
\text { Okhotsk midden }\end{array}$ & Ch & $\begin{array}{l}\text { KBP } \\
0447\end{array}$ & $\begin{array}{l}\text { OS- } \\
59343\end{array}$ & $1310 \pm 25$ & $\begin{array}{l}1293- \\
1183 \\
\end{array}$ & $E$ \\
\hline 3 & A-South & Urup & Ainu Creek 1 & Test Pit $1,62 \mathrm{cmbs}, 45 \mathrm{~cm} \mathrm{~N}$ & $\mathrm{Ch}$ & $\begin{array}{l}\text { KBP } \\
0290\end{array}$ & $\begin{array}{l}\text { OS- } \\
59347\end{array}$ & $1290 \pm 30$ & $\begin{array}{l}1286- \\
1180\end{array}$ & $E$ \\
\hline 3 & A-South & Urup & Ainu Creek 1 & Test Pit 4, Level 3, midden & $\mathrm{Ch}$ & $\begin{array}{l}\text { KBP } \\
0352\end{array}$ & $\begin{array}{l}\text { OS- } \\
98015\end{array}$ & $1290 \pm 25$ & $\begin{array}{l}1285- \\
1181\end{array}$ & $E$ \\
\hline 3 & A-South & Urup & Ainu Creek 1 & Test Pit 1, $127 \mathrm{cmbs}$ & Ch & $\begin{array}{l}\text { KBP } \\
0272\end{array}$ & $\begin{array}{l}\text { OS- } \\
59382\end{array}$ & $1160 \pm 25$ & $1176-986$ & $E$ \\
\hline 3 & A-South & Urup & Ainu Creek 1 & $\begin{array}{l}\text { Test Pit 1; } 115 \mathrm{cmbs}, 90 \mathrm{~cm} \text {, } \\
\text { N Charcoal Sample }\end{array}$ & $\mathrm{Ch}$ & $\begin{array}{l}\text { KBP } \\
0268\end{array}$ & $\begin{array}{l}\text { OS- } \\
59205\end{array}$ & $1120 \pm 25$ & $1167-960$ & $E$ \\
\hline 3 & A-South & Urup & Ainu Creek 1 & $\begin{array}{l}\text { Test Pit 4, Level 5, } 90 \text { - } \\
95 \mathrm{~cm}\end{array}$ & $\mathrm{Ch}$ & $\begin{array}{l}\text { KBP } \\
0368\end{array}$ & $\begin{array}{l}\text { OS- } \\
59374\end{array}$ & $880 \pm 30$ & $908-729$ & $\mathrm{D}$ \\
\hline 3 & A-South & Urup & Aleutka Bay & $\begin{array}{l}1978 \text { trench- N Profile, } \\
\text { lowest CZ, 14C\#1 }\end{array}$ & $\mathrm{Ch}$ & $\begin{array}{l}\text { IKIP } \\
0304\end{array}$ & $\begin{array}{l}\text { AA- } \\
44266\end{array}$ & $2255 \pm 44$ & $\begin{array}{l}2348- \\
2153\end{array}$ & A \\
\hline 3 & A-South & Urup & Kama & $\begin{array}{l}\text { Profile } 2, \text { lowest lamina } \\
\text { (sample } 1 \text { ) }\end{array}$ & Ch & $\begin{array}{l}\mathrm{IKIP} \\
0326\end{array}$ & $\begin{array}{l}\text { AA- } \\
40950\end{array}$ & $2157 \pm 37$ & $\begin{array}{l}2309- \\
2013\end{array}$ & $A$ \\
\hline 3 & A-South & Urup & Kama & Profile 2, CZ 4 (sample 2) & Ch & $\begin{array}{l}\text { IKIP } \\
0327\end{array}$ & $\begin{array}{l}\text { AA- } \\
41560\end{array}$ & $2122 \pm 43$ & $\begin{array}{l}2304- \\
1990\end{array}$ & A \\
\hline 3 & A-South & Urup & Kama & Profile 2, CZ 3 floor 3 & $\mathrm{Ch}$ & $\begin{array}{l}\text { IKIP } \\
0331\end{array}$ & $\begin{array}{l}\text { AA- } \\
44272\end{array}$ & $2039 \pm 39$ & $\begin{array}{l}2115- \\
1899\end{array}$ & $A$ \\
\hline 3 & A-South & Urup & Kama & Profile 1, CZ 5 & $\mathrm{Ch}$ & $\begin{array}{l}\text { IKIP } \\
0317\end{array}$ & $\begin{array}{l}\text { AA- } \\
41559\end{array}$ & $2002 \pm 34$ & $\begin{array}{l}2041- \\
1876\end{array}$ & $A$ \\
\hline 3 & A-South & Urup & Kama & Profile 2. CZ 3 (sample 4) & $\mathrm{Ch}$ & IKIP & AA- & $1967 \pm 48$ & 2041- & A \\
\hline
\end{tabular}




\begin{tabular}{|c|c|c|c|c|c|c|c|c|c|c|}
\hline & & & & & & 0329 & 41561 & & 1818 & \\
\hline 3 & A-South & Urup & Kama & $\begin{array}{l}\text { Profile 2, highest lamina } \\
\text { (Sample 3) }\end{array}$ & Ch & $\begin{array}{l}\mathrm{IKIP} \\
0328\end{array}$ & $\begin{array}{l}\text { AA- } \\
44271\end{array}$ & $1855 \pm 38$ & $\begin{array}{l}1879- \\
1708\end{array}$ & $A$ \\
\hline 3 & A-South & Urup & Kama & $\begin{array}{l}\text { Profile 2, CZ } 3 \text { floor } 2 \\
\text { hearth }\end{array}$ & $\mathrm{Ch}$ & $\begin{array}{l}\text { IKIP } \\
0330\end{array}$ & $\begin{array}{l}\text { AA- } \\
41562\end{array}$ & $1731 \pm 47$ & $\begin{array}{l}1780- \\
1537\end{array}$ & A \\
\hline 3 & A-South & Urup & Kama & Profile 1, CZ 6 & $\mathrm{Ch}$ & $\begin{array}{l}\text { IKIP } \\
0315\end{array}$ & $\begin{array}{l}\text { AA- } \\
44270\end{array}$ & $1621 \pm 37$ & $\begin{array}{l}1604- \\
1410\end{array}$ & A \\
\hline 3 & A-South & Urup & Kama & Profile 1, level 3B & $\mathrm{Ch}$ & $\begin{array}{l}\text { IKIP } \\
0311 \\
\end{array}$ & $\begin{array}{l}\text { AA- } \\
44267\end{array}$ & $1364 \pm 37$ & $\begin{array}{l}1345- \\
1186 \\
\end{array}$ & A \\
\hline 3 & A-South & Urup & Kama & Profile 1 , level $3 A$ & $\mathrm{Ch}$ & $\begin{array}{l}\text { IKIP } \\
0314\end{array}$ & $\begin{array}{l}\text { AA- } \\
41557\end{array}$ & $1345 \pm 40$ & $\begin{array}{l}1330- \\
1182\end{array}$ & A \\
\hline 3 & A-South & Urup & Kama & Profile 1, burnt layer & $\mathrm{Ch}$ & $\begin{array}{l}\text { IKIP } \\
0312\end{array}$ & $\begin{array}{l}\text { AA- } \\
44268\end{array}$ & $1205 \pm 38$ & $\begin{array}{l}1261- \\
1007\end{array}$ & $A$ \\
\hline 3 & A-South & Urup & Kama & Profile 1, CZ 6 & Ch & $\begin{array}{l}\text { IKIP } \\
0315\end{array}$ & $\begin{array}{l}\text { AA- } \\
40949\end{array}$ & $1016 \pm 38$ & 1049-798 & A \\
\hline 3 & A-South & Urup & Kama & Profile 1, CZ 2 & $\mathrm{Ch}$ & $\begin{array}{l}\text { IKIP } \\
0313\end{array}$ & $\begin{array}{l}\text { AA- } \\
44269\end{array}$ & $916 \pm 38$ & $922-745$ & $A$ \\
\hline 3 & A-South & Urup & Kama & $\begin{array}{l}\text { Profile 1, CZ } 1 \text { (post bomb } \\
\text { age) }\end{array}$ & $\mathrm{Ch}$ & $\begin{array}{l}\text { IKIP } \\
0316\end{array}$ & $\begin{array}{l}\text { AA- } \\
41558\end{array}$ & >Modern & $\mathrm{n} / \mathrm{a}$ & A \\
\hline 3 & A-South & Urup & Kapsul & $\begin{array}{l}\text { Test Pit 1, Level 1; Test Pit } \\
\text { 1, Level 1, }\end{array}$ & $\mathrm{Ch}$ & $\begin{array}{l}\text { KBP } \\
0665\end{array}$ & $\begin{array}{l}\text { OS- } \\
97895\end{array}$ & $1200 \pm 30$ & $\begin{array}{l}1236- \\
1010\end{array}$ & $E$ \\
\hline 3 & A-South & Urup & Kapsul & Test Pit 4 & $\mathrm{Ch}$ & $\begin{array}{l}\text { KBP } \\
0262\end{array}$ & $\begin{array}{l}\text { OS- } \\
59414\end{array}$ & $815 \pm 25$ & $781-685$ & $E$ \\
\hline 3 & A-South & Urup & Kapsul & Test Pit 3, Level 3 & $\mathrm{Ch}$ & $\begin{array}{l}\text { KBP } \\
0256\end{array}$ & $\begin{array}{l}\text { OS- } \\
59385\end{array}$ & $135 \pm 35$ & $281-6$ & $C$ \\
\hline 3 & A-South & Urup & Kapsul & Test Pit 3, Level 2 & $\mathrm{Ch}$ & $\begin{array}{l}\text { KBP } \\
0255\end{array}$ & $\begin{array}{l}\text { OS- } \\
59497\end{array}$ & $80 \pm 25$ & $259-30$ & $E$ \\
\hline 3 & A-South & Urup & Kapsul & Test Pit 2, Level 2 & $\mathrm{Ch}$ & $\begin{array}{l}\text { KBP } \\
0248\end{array}$ & $\begin{array}{l}\text { "OS- } \\
\text { 59383; }\end{array}$ & & & \\
\hline $\begin{array}{l}\text { OS- } \\
59496 "\end{array}$ & $>$ Modern & $\mathrm{n} / \mathrm{a}$ & $E$ & & & & & & & \\
\hline 3 & A-South & Urup & $\begin{array}{l}\text { Kompaneyski } \\
1\end{array}$ & Test Pit 2, n.a., Sample E & $\mathrm{Ch}$ & $\begin{array}{l}\text { KBP } \\
4316\end{array}$ & $\begin{array}{l}\text { OS- } \\
79912\end{array}$ & $2100 \pm 25$ & $\begin{array}{l}2137- \\
2000\end{array}$ & C \\
\hline 3 & A-South & Urup & Kompaneyski & Test Pit 2, Level 4C, bulk & $\mathrm{Ch}$ & KBP & OS- & $2010 \pm 30$ & 2041- & $E$ \\
\hline
\end{tabular}




\begin{tabular}{|c|c|c|c|c|c|c|c|c|c|c|}
\hline & & & 1 & & & 4308 & 98006 & & 1885 & \\
\hline 3 & A-South & Urup & $\begin{array}{l}\text { Kompaneyski } \\
1\end{array}$ & Test Pit 2, Level 4E & $\mathrm{Ch}$ & $\begin{array}{l}\text { KBP } \\
4310\end{array}$ & $\begin{array}{l}\text { OS- } \\
98007\end{array}$ & $2000 \pm 20$ & $\begin{array}{l}1994- \\
1897\end{array}$ & $E$ \\
\hline 3 & A-South & Urup & $\begin{array}{l}\text { Kompaneyski } \\
1\end{array}$ & Test Pit 2, n.a., Sample F & $\mathrm{Ch}$ & $\begin{array}{l}\text { KBP } \\
4317\end{array}$ & $\begin{array}{l}\text { OS- } \\
79913\end{array}$ & $1200 \pm 25$ & $\begin{array}{l}1225- \\
1060\end{array}$ & $E$ \\
\hline 3 & A-South & Urup & $\begin{array}{l}\text { Kompaneyski } \\
1\end{array}$ & $\begin{array}{l}\text { Deflation Basin (NW), } \\
\text { below green grey tephra, } \\
2006 \text { exposure cleaning. }\end{array}$ & $\mathrm{Ch}$ & $\begin{array}{l}\text { KBP } \\
0421\end{array}$ & $\begin{array}{l}\text { OS- } \\
59415\end{array}$ & $170 \pm 30$ & $291-0$ & $E$ \\
\hline 3 & A-South & Urup & Tokotan 1 & $\begin{array}{l}\text { Erosion face: creek erosion } \\
\text { cut } 30 \mathrm{~m} \text { up along creek } \\
\text { from M lake; } 20-25 \mathrm{cmbs} \text {, } \\
\text { just belowturf level }\end{array}$ & $\mathrm{Ch}$ & $\begin{array}{l}\text { KBP } \\
0398\end{array}$ & $\begin{array}{l}\text { OS- } \\
93601\end{array}$ & $990 \pm 25$ & $960-799$ & $E$ \\
\hline 3 & A-South & Urup & Tokotan 4 & Test Pit 1, Level 1 & $\mathrm{Ch}$ & $\begin{array}{l}\text { KBP } \\
0418\end{array}$ & $\begin{array}{l}\text { OS- } \\
95613\end{array}$ & $1320 \pm 25$ & $\begin{array}{l}1296- \\
1184\end{array}$ & $E$ \\
\hline 3 & A-South & Urup & Tokotan 4 & Test Pit 1, Level 2 & $\mathrm{Ch}$ & $\begin{array}{l}\text { KBP } \\
0419\end{array}$ & $\begin{array}{l}\text { OS- } \\
95614\end{array}$ & $1260 \pm 35$ & $\begin{array}{l}1283- \\
1083\end{array}$ & $E$ \\
\hline 3 & A-South & Urup & Vasino 1 & $\begin{array}{l}\text { Test Pit 2, Level 2, } 130 \\
\text { cmbs }\end{array}$ & $\mathrm{Ch}$ & $\begin{array}{l}\text { KBP } \\
0230\end{array}$ & $\begin{array}{l}\text { OS- } \\
93600\end{array}$ & $3510 \pm 30$ & $\begin{array}{l}3867- \\
3697\end{array}$ & C \\
\hline 3 & A-South & Urup & Vasino 1 & Test Pit $1,138 \mathrm{cmbs}$ & $\mathrm{Ch}$ & $\begin{array}{l}\text { KBP } \\
0200\end{array}$ & $\begin{array}{l}\text { OS- } \\
93599\end{array}$ & $2080 \pm 30$ & $\begin{array}{l}2140- \\
1952 \\
\end{array}$ & $E$ \\
\hline 4 & A-South & Chirpoi & $\begin{array}{l}\text { Peschanaya } \\
\text { Bay } 1\end{array}$ & Camp Profile, upper hearth & $\mathrm{Ch}$ & $\begin{array}{l}\text { IKIP } \\
0291\end{array}$ & $\begin{array}{l}\text { AA- } \\
42208\end{array}$ & $2435 \pm 43$ & $\begin{array}{l}2704- \\
2354\end{array}$ & A \\
\hline 4 & A-South & Chirpoi & $\begin{array}{l}\text { Peschanaya } \\
\text { Bay } 1\end{array}$ & $\begin{array}{l}\text { Camp Profile, scoria layer, } \\
61-63 \text { cmbs. }\end{array}$ & $\mathrm{Ch}$ & $\begin{array}{l}\text { IKIP } \\
0283\end{array}$ & $\begin{array}{l}\text { AA- } \\
42205\end{array}$ & $2290 \pm 43$ & $\begin{array}{l}2360- \\
2155\end{array}$ & $A$ \\
\hline 4 & A-South & Chirpoi & $\begin{array}{l}\text { Peschanaya } \\
\text { Bay } 1\end{array}$ & $\begin{array}{l}\text { Camp Profile, fr. White } \\
\text { tephra- } 43 \text { meters fr. North } \\
\text { end of profile }\end{array}$ & $\mathrm{Ch}$ & $\begin{array}{l}\text { IKIP } \\
0292\end{array}$ & $\begin{array}{l}\text { AA- } \\
42209\end{array}$ & $2178 \pm 42$ & $\begin{array}{l}2320- \\
2060\end{array}$ & $A$ \\
\hline 4 & A-South & Chirpoi & $\begin{array}{l}\text { Peschanaya } \\
\text { Bay } 1\end{array}$ & $\begin{array}{l}\text { Camp Profile, near } \\
\text { debitage, stemmed point } \\
\text { layer }\end{array}$ & $\mathrm{Ch}$ & $\begin{array}{l}\text { IKIP } \\
0293\end{array}$ & $\begin{array}{l}\text { AA- } \\
42210\end{array}$ & $2088 \pm 44$ & $\begin{array}{l}2294- \\
1935\end{array}$ & A \\
\hline 4 & A-South & Chirpoi & $\begin{array}{l}\text { Peschanaya } \\
\text { Bay } 1\end{array}$ & $\begin{array}{l}\text { Camp Profile, Stratwn E, } \\
\text { hearth }\end{array}$ & $\mathrm{Ch}$ & $\begin{array}{l}\text { IKIP } \\
0288\end{array}$ & $\begin{array}{l}\text { AA- } \\
40947\end{array}$ & $2080 \pm 57$ & $\begin{array}{l}2300- \\
1897\end{array}$ & A \\
\hline 4 & A-South & Chirpoi & $\begin{array}{l}\text { Peschanaya } \\
\text { Bay } 1\end{array}$ & $\begin{array}{l}\text { Camp Profile, north hearth, } \\
3-5 \mathrm{~cm} \text { above black sand }\end{array}$ & $\mathrm{Ch}$ & $\begin{array}{l}\text { IKIP } \\
0284\end{array}$ & $\begin{array}{l}\text { AA- } \\
42206\end{array}$ & $1959 \pm 42$ & $\begin{array}{l}1995- \\
1822\end{array}$ & $A$ \\
\hline
\end{tabular}




\begin{tabular}{|c|c|c|c|c|c|c|c|c|c|c|}
\hline 4 & A-South & Chirpoi & $\begin{array}{l}\text { Peschanaya } \\
\text { Bay } 1\end{array}$ & Camp Profile, hearth \#2 & $\mathrm{Ch}$ & $\begin{array}{l}\text { IKIP } \\
0282\end{array}$ & $\begin{array}{l}\text { AA- } \\
42204\end{array}$ & $1938 \pm 43$ & $\begin{array}{l}1994- \\
1742\end{array}$ & $A$ \\
\hline 4 & A-South & Chirpoi & $\begin{array}{l}\text { Peschanaya } \\
\text { Bay } 1\end{array}$ & Camp Profile, hearth \#1 & $\mathrm{Ch}$ & $\begin{array}{l}\text { IKIP } \\
0295\end{array}$ & $\begin{array}{l}\text { AA- } \\
42211 \\
\end{array}$ & $1909 \pm 40$ & $\begin{array}{l}1943- \\
1732 \\
\end{array}$ & A \\
\hline 4 & A-South & Chirpoi & $\begin{array}{l}\text { Peschanaya } \\
\text { Bay } 1\end{array}$ & Camp Profile, near Adze & $\mathrm{Ch}$ & $\begin{array}{l}\text { IKIP } \\
0289\end{array}$ & $\begin{array}{l}\text { AA- } \\
42207\end{array}$ & $1832 \pm 41$ & $\begin{array}{l}1873- \\
1629\end{array}$ & A \\
\hline 4 & A-South & Chirpoi & $\begin{array}{l}\text { Peschanaya } \\
\text { Bay } 1\end{array}$ & Camp Profile, south midden & $\mathrm{Ch}$ & $\begin{array}{l}\text { IKIP } \\
0263\end{array}$ & $\begin{array}{l}\text { AA- } \\
42203\end{array}$ & $1272 \pm 58$ & $\begin{array}{l}1295- \\
1066 \\
\end{array}$ & A \\
\hline 4 & A-South & Chirpoi & $\begin{array}{l}\text { Peschanaya } \\
\text { Bay } 1\end{array}$ & $\begin{array}{l}\text { House } 31 \text {, Unit B3 (outside } \\
\text { house wall) }\end{array}$ & BM & $\begin{array}{l}\text { IKIP } \\
0217\end{array}$ & $\begin{array}{l}\text { AA- } \\
40946\end{array}$ & $825 \pm 36$ & $522-3825$ & A \\
\hline 4 & A-South & Chirpoi & $\begin{array}{l}\text { Peschanaya } \\
\text { Bay } 1\end{array}$ & $\begin{array}{l}\text { Probe Survey, house pit } \\
\text { (GPS 019), 60-75 cm }\end{array}$ & $\mathrm{Ch}$ & $\begin{array}{l}\text { KBP } \\
4264\end{array}$ & $\begin{array}{l}\text { OS- } \\
95703\end{array}$ & $275 \pm 20$ & $429-286$ & $E$ \\
\hline 4 & A-South & Chirpoi & $\begin{array}{l}\text { Peschanaya } \\
\text { Bay } 1\end{array}$ & $\begin{array}{l}\text { House 31, Unit B2 (SE), } \\
\text { hearth fill }\end{array}$ & $\mathrm{Ch}$ & $\begin{array}{l}\text { IKIP } \\
0215\end{array}$ & $\begin{array}{l}\text { AA- } \\
40945\end{array}$ & $162 \pm 40$ & $289-0$ & A \\
\hline 5 & $\begin{array}{l}\text { B-South } \\
\text { Center }\end{array}$ & Simushir & Brotona Bay 2 & Erosion face, sample \#5 & $\mathrm{Ch}$ & $\begin{array}{l}\mathrm{IKIP} \\
0151 \\
\end{array}$ & $\begin{array}{l}\text { AA- } \\
44262\end{array}$ & $1818 \pm 43$ & $\begin{array}{l}1865- \\
1623 \\
\end{array}$ & A \\
\hline 5 & $\begin{array}{l}\text { B-South } \\
\text { Center }\end{array}$ & Simushir & Brotona Bay 2 & Profile 2, post mold & $\mathrm{Ch}$ & $\begin{array}{l}\text { IKIP } \\
0154\end{array}$ & $\begin{array}{l}\text { AA- } \\
44264\end{array}$ & $1732 \pm 43$ & $\begin{array}{l}1774- \\
1540 \\
\end{array}$ & A \\
\hline 5 & $\begin{array}{l}\text { B-South } \\
\text { Center }\end{array}$ & Simushir & Brotona Bay 2 & $\begin{array}{l}\text { Profile } 2, \text { lower charcoal } \\
\text { layer }\end{array}$ & $\mathrm{Ch}$ & $\begin{array}{l}\mathrm{IKIP} \\
0153\end{array}$ & $\begin{array}{l}\text { AA- } \\
40944\end{array}$ & $1695 \pm 36$ & $\begin{array}{l}1698- \\
1535\end{array}$ & A \\
\hline 5 & $\begin{array}{l}\text { B-South } \\
\text { Center }\end{array}$ & Simushir & Brotona Bay 2 & Erosion face, sample \#3 & $\mathrm{Ch}$ & $\begin{array}{l}\text { IKIP } \\
0149\end{array}$ & $\begin{array}{l}\text { AA- } \\
44260\end{array}$ & $1164 \pm 44$ & $1222-970$ & A \\
\hline 5 & $\begin{array}{l}\text { B-South } \\
\text { Center }\end{array}$ & Simushir & Brotona Bay 2 & Erosion face, sample \#2 & $\mathrm{Ch}$ & $\begin{array}{l}\text { IKIP } \\
0148 \\
\end{array}$ & $\begin{array}{l}\text { AA- } \\
44259\end{array}$ & $1121 \pm 38$ & $1174-939$ & A \\
\hline 5 & $\begin{array}{l}\text { B-South } \\
\text { Center }\end{array}$ & Simushir & Brotona Bay 2 & Erosion face, sample \#4 & $\mathrm{Ch}$ & $\begin{array}{l}\text { IKIP } \\
0150\end{array}$ & $\begin{array}{l}\text { AA- } \\
44261\end{array}$ & $1011 \pm 40$ & $1048-796$ & A \\
\hline 5 & $\begin{array}{l}\text { B-South } \\
\text { Center }\end{array}$ & Simushir & Brotona Bay 2 & Erosion face, sample \#1 & $\mathrm{Ch}$ & $\begin{array}{l}\text { IKIP } \\
0147\end{array}$ & $\begin{array}{l}\text { AA- } \\
44258\end{array}$ & $1003 \pm 43$ & $982-794$ & A \\
\hline 5 & $\begin{array}{l}\text { B-South } \\
\text { Center }\end{array}$ & Simushir & Brotona Bay 2 & $\begin{array}{l}\text { Profile 2, upper charcoal } \\
\text { layer }\end{array}$ & $\mathrm{Ch}$ & $\begin{array}{l}\text { IKIP } \\
0152 \\
\end{array}$ & $\begin{array}{l}\text { AA- } \\
44263 \\
\end{array}$ & $935 \pm 42$ & $930-747$ & A \\
\hline 5 & $\begin{array}{l}\text { B-South } \\
\text { Center }\end{array}$ & Simushir & Brotona Bay 2 & $\begin{array}{l}\text { Profile } 2 \text {, between upper } \\
\text { and lower layers }\end{array}$ & $\mathrm{Ch}$ & $\begin{array}{l}\text { IKIP } \\
0155\end{array}$ & $\begin{array}{l}\text { AA- } \\
44265\end{array}$ & $897 \pm 38$ & $914-735$ & A \\
\hline 5 & $\begin{array}{l}\text { B-South } \\
\text { Center }\end{array}$ & Simushir & Nakotamori 1 & $\begin{array}{l}\text { Erosion face, cultural } \\
\text { deposit below } 1 \mathrm{~m} \text {. of }\end{array}$ & $\mathrm{Ch}$ & $\begin{array}{l}\text { KBP } \\
2153 c\end{array}$ & $\begin{array}{l}\text { OS- } \\
67622\end{array}$ & $140 \pm 25$ & $281-6$ & $\mathrm{E}$ \\
\hline
\end{tabular}




\begin{tabular}{|c|c|c|c|c|c|c|c|c|c|c|}
\hline & & & & $\begin{array}{l}\text { volcanic overburden, with } \\
\text { unburned wood, lithics, } \\
\text { bone fragments and } \\
\text { cobbles. GPS } 117\end{array}$ & & & & & & \\
\hline 5 & $\begin{array}{l}\text { B-South } \\
\text { Center }\end{array}$ & Simushir & Nakotamori 1 & $\begin{array}{l}\text { Erosion face, cultural } \\
\text { deposit below } 1 \mathrm{~m} \text {. of } \\
\text { volcanic overburden, with } \\
\text { unburned wood, lithics, } \\
\text { bone fragments and } \\
\text { cobbles. GPS } 117\end{array}$ & $\mathrm{Ch}$ & $\begin{array}{l}\text { KBP } \\
2153 b\end{array}$ & $\begin{array}{l}\text { OS- } \\
67618\end{array}$ & $105 \pm 25$ & $268-20$ & $E$ \\
\hline 5 & $\begin{array}{l}\text { B-South } \\
\text { Center }\end{array}$ & Simushir & $\begin{array}{l}\text { Vodopadnaya } \\
2\end{array}$ & $\begin{array}{l}\text { Probe Survey, house pit } \\
\text { probe } 16,(\text { GPS 394) }\end{array}$ & $\mathrm{Ch}$ & $\begin{array}{l}\text { KBP } \\
1958\end{array}$ & $\begin{array}{l}\text { OS- } \\
95627\end{array}$ & $2170 \pm 30$ & $\begin{array}{l}2309- \\
2065\end{array}$ & C \\
\hline 5 & $\begin{array}{l}\text { B-South } \\
\text { Center }\end{array}$ & Simushir & $\begin{array}{l}\text { Vodopadnaya } \\
2\end{array}$ & $\begin{array}{l}\text { Probe Survey, house pit } \\
\text { probe } 25 \text { (GPS 403) }\end{array}$ & $\mathrm{Ch}$ & $\begin{array}{l}\text { KBP } \\
1967\end{array}$ & $\begin{array}{l}\text { OS- } \\
95629\end{array}$ & $2170 \pm 30$ & $\begin{array}{l}2309- \\
2065\end{array}$ & $E$ \\
\hline 5 & $\begin{array}{l}\text { B-South } \\
\text { Center }\end{array}$ & Simushir & $\begin{array}{l}\text { Vodopadnaya } \\
2\end{array}$ & Test Pit 3, Level 4, $40 \mathrm{cmbs}$ & $\mathrm{Ch}$ & $\begin{array}{l}\text { KBP } \\
0575\end{array}$ & $\begin{array}{l}\text { OS- } \\
97894\end{array}$ & $2140 \pm 25$ & $\begin{array}{l}2300- \\
2010\end{array}$ & $E$ \\
\hline 5 & $\begin{array}{l}\text { B-South } \\
\text { Center }\end{array}$ & Simushir & $\begin{array}{l}\text { Vodopadnaya } \\
2\end{array}$ & $\begin{array}{l}\text { Probe Survey, house pit } \\
\text { probe } 19 \text { (GPS 397) }\end{array}$ & $\mathrm{Ch}$ & $\begin{array}{l}\text { KBP } \\
1954\end{array}$ & $\begin{array}{l}\text { OS- } \\
95626\end{array}$ & $2080 \pm 25$ & $\begin{array}{l}2125- \\
1990\end{array}$ & $E$ \\
\hline 5 & $\begin{array}{l}\text { B-South } \\
\text { Center }\end{array}$ & Simushir & $\begin{array}{l}\text { Vodopadnaya } \\
2\end{array}$ & $\begin{array}{l}\text { Test Pit 1, Level 2, 20-30 } \\
\mathrm{cmbs}\end{array}$ & $\mathrm{Ch}$ & $\begin{array}{l}\text { KBP } \\
0561\end{array}$ & $\begin{array}{l}\text { OS- } \\
97891\end{array}$ & $2010 \pm 30$ & $\begin{array}{l}2041- \\
1885\end{array}$ & $E$ \\
\hline 5 & $\begin{array}{l}\text { B-South } \\
\text { Center }\end{array}$ & Simushir & $\begin{array}{l}\text { Vodopadnaya } \\
2\end{array}$ & $\begin{array}{l}\text { Test Pit 1, Level 4, 40-50 } \\
\text { cmbs }\end{array}$ & $\mathrm{Ch}$ & $\begin{array}{l}\text { KBP } \\
0567\end{array}$ & $\begin{array}{l}\text { OS- } \\
97892\end{array}$ & $2000 \pm 25$ & $\begin{array}{l}1998- \\
1891\end{array}$ & $E$ \\
\hline 5 & $\begin{array}{l}\text { B-South } \\
\text { Center }\end{array}$ & Simushir & $\begin{array}{l}\text { Vodopadnaya } \\
2\end{array}$ & $\begin{array}{l}\text { Probe Survey, house pit } \\
\text { probe } 22 \text { (GPS 400) }\end{array}$ & $\mathrm{Ch}$ & $\begin{array}{l}\text { KBP } \\
1968\end{array}$ & $\begin{array}{l}\text { OS- } \\
95630\end{array}$ & $1980 \pm 30$ & $\begin{array}{l}1994- \\
1873\end{array}$ & $E$ \\
\hline 5 & $\begin{array}{l}\text { B-South } \\
\text { Center }\end{array}$ & Simushir & $\begin{array}{l}\text { Vodopadnaya } \\
2\end{array}$ & $\begin{array}{l}\text { Probe Survey, house pit } \\
\text { probe } 13 \text { (GPS 391) }\end{array}$ & $\mathrm{Ch}$ & $\begin{array}{l}\text { KBP } \\
1952\end{array}$ & $\begin{array}{l}\text { OS- } \\
95625\end{array}$ & $1970 \pm 25$ & $\begin{array}{l}1989- \\
1872\end{array}$ & $E$ \\
\hline 5 & $\begin{array}{l}\text { B-South } \\
\text { Center }\end{array}$ & Simushir & $\begin{array}{l}\text { Vodopadnaya } \\
2\end{array}$ & $\begin{array}{l}\text { Test Pit 2, Level 1, 15-23 } \\
\mathrm{cmbs}\end{array}$ & $\mathrm{Ch}$ & $\begin{array}{l}\text { KBP } \\
0462\end{array}$ & $\begin{array}{l}\text { OS- } \\
59199\end{array}$ & $1940 \pm 40$ & $\begin{array}{l}1994- \\
1815\end{array}$ & $E$ \\
\hline 5 & $\begin{array}{l}\text { B-South } \\
\text { Center }\end{array}$ & Simushir & $\begin{array}{l}\text { Vodopadnaya } \\
2\end{array}$ & $\begin{array}{l}\text { Unit 3, Level } 3 \text { (bottom), } \\
\text { North, Strat } 1 \text {, above } \\
\text { tephra, } 43-47 \mathrm{cmbs} \text {. }\end{array}$ & $\mathrm{Ch}$ & $\begin{array}{l}\text { KBP } \\
1825\end{array}$ & $\begin{array}{l}\text { OS- } \\
67470\end{array}$ & $1930 \pm 35$ & $\begin{array}{l}1987- \\
1814\end{array}$ & $E$ \\
\hline 5 & $\begin{array}{l}\text { B-South } \\
\text { Center }\end{array}$ & Simushir & $\begin{array}{l}\text { Vodopadnaya } \\
2\end{array}$ & $\begin{array}{l}\text { Unit 3, Level } 5 \text { (base), base } \\
\text { of exc., Strat } 1\end{array}$ & $\mathrm{Ch}$ & $\begin{array}{l}\text { KBP } \\
1830\end{array}$ & $\begin{array}{l}\text { OS- } \\
67472\end{array}$ & $1930 \pm 30$ & $\begin{array}{l}1946- \\
1820\end{array}$ & $E$ \\
\hline 5 & B-South & Simushir & Vodopadnaya & Probe Survey, house pit & $\mathrm{Ch}$ & KBP & OS- & $1920 \pm 25$ & 1926- & $\mathrm{E}$ \\
\hline
\end{tabular}




\begin{tabular}{|c|c|c|c|c|c|c|c|c|c|c|}
\hline & Center & & 2 & probe 28 , (GPS 406) & & 1951 & 95624 & & 1820 & \\
\hline 5 & $\begin{array}{l}\text { B-South } \\
\text { Center }\end{array}$ & Simushir & $\begin{array}{l}\text { Vodopadnaya } \\
2\end{array}$ & $\begin{array}{l}\text { house pit Probe } 31 ; \text { GPS } \\
\text { point 0409; , house pit } \\
\text { Probe } 31, \text { GPS point } 0409\end{array}$ & $\mathrm{Ch}$ & $\begin{array}{l}\text { KBP } \\
1965\end{array}$ & $\begin{array}{l}\text { OS- } \\
95628\end{array}$ & $1900 \pm 30$ & $\begin{array}{l}1922- \\
1737\end{array}$ & $E$ \\
\hline 5 & $\begin{array}{l}\text { B-South } \\
\text { Center }\end{array}$ & Simushir & $\begin{array}{l}\text { Vodopadnaya } \\
2\end{array}$ & $\begin{array}{l}\text { Test Pit 1, Level } 3 \text { from } 30- \\
40 \mathrm{cmbs}\end{array}$ & $\mathrm{Ch}$ & $\begin{array}{l}\text { KBP } \\
0563\end{array}$ & \begin{tabular}{|l|} 
OS- \\
97890 \\
\end{tabular} & $1890 \pm 20$ & \begin{tabular}{|l|}
$1888-$ \\
1741 \\
\end{tabular} & $E$ \\
\hline 5 & $\begin{array}{l}\text { B-South } \\
\text { Center }\end{array}$ & Simushir & $\begin{array}{l}\text { Vodopadnaya } \\
2\end{array}$ & $\begin{array}{l}\text { Unit 3, Level } 3 \text { (top), 31-36 } \\
\text { cmbs, below coarse } \\
\text { cinders, Strat } 1\end{array}$ & $\mathrm{Ch}$ & $\begin{array}{l}\text { KBP } \\
1827\end{array}$ & $\begin{array}{l}\text { OS- } \\
67587\end{array}$ & $1850 \pm 30$ & $\begin{array}{l}1865- \\
1715\end{array}$ & $E$ \\
\hline 5 & $\begin{array}{l}\text { B-South } \\
\text { Center }\end{array}$ & Simushir & $\begin{array}{l}\text { Vodopadnaya } \\
2\end{array}$ & $\begin{array}{l}\text { Test Pit 1, Level 1, 0-20 } \\
\text { cmbs }\end{array}$ & $\mathrm{Ch}$ & $\begin{array}{l}\text { KBP } \\
1013\end{array}$ & \begin{tabular}{|l|} 
OS- \\
59204
\end{tabular} & $1820 \pm 30$ & $\begin{array}{l}1860- \\
1630\end{array}$ & $\mathrm{E}$ \\
\hline 5 & $\begin{array}{l}\text { B-South } \\
\text { Center }\end{array}$ & Simushir & $\begin{array}{l}\text { Vodopadnaya } \\
2\end{array}$ & $\begin{array}{l}\text { Unit 3, Level 5, above } \\
\text { sterile }\end{array}$ & $\mathrm{Ch}$ & $\begin{array}{l}\text { KBP } \\
1460\end{array}$ & $\begin{array}{l}\text { OS- } \\
97905\end{array}$ & $1820 \pm 25$ & $\begin{array}{l}1824- \\
1639 \\
\end{array}$ & $E$ \\
\hline 5 & $\begin{array}{l}\text { B-South } \\
\text { Center }\end{array}$ & Simushir & $\begin{array}{l}\text { Vodopadnaya } \\
2\end{array}$ & Unit 4, Level 8: $68 \mathrm{cmbd}$ & $\mathrm{Ch}$ & $\begin{array}{l}\text { KBP } \\
1391\end{array}$ & $\begin{array}{l}\text { OS- } \\
67420\end{array}$ & $1800 \pm 25$ & $\begin{array}{l}1818- \\
1628\end{array}$ & $E$ \\
\hline 5 & $\begin{array}{l}\text { B-South } \\
\text { Center }\end{array}$ & Simushir & $\begin{array}{l}\text { Vodopadnaya } \\
2\end{array}$ & $\begin{array}{l}\text { Test Pit 3, Level 4, below } \\
\text { tephra (?) at } 42 \text { cmbs in } \\
\text { North wall }\end{array}$ & $\mathrm{Ch}$ & $\begin{array}{l}\text { KBP } \\
0576\end{array}$ & $\begin{array}{l}\text { OS- } \\
59346\end{array}$ & $1740 \pm 30$ & $\begin{array}{l}1715- \\
1565\end{array}$ & $\mathrm{E}$ \\
\hline 5 & $\begin{array}{l}\text { B-South } \\
\text { Center }\end{array}$ & Simushir & $\begin{array}{l}\text { Vodopadnaya } \\
2\end{array}$ & Unit 1, Level 4C & $\mathrm{Ch}$ & $\begin{array}{l}\text { KBP } \\
1474 \\
\end{array}$ & \begin{tabular}{|l|} 
OS- \\
97906 \\
\end{tabular} & $1740 \pm 30$ & \begin{tabular}{|l|}
$1715-$ \\
1565 \\
\end{tabular} & $E$ \\
\hline 5 & $\begin{array}{l}\text { B-South } \\
\text { Center }\end{array}$ & Simushir & $\begin{array}{l}\text { Vodopadnaya } \\
2\end{array}$ & Test Pit 3, Level 7 & $\mathrm{Ch}$ & $\begin{array}{l}\text { KBP } \\
0584 \\
\end{array}$ & \begin{tabular}{|l|} 
OS- \\
59203 \\
\end{tabular} & $1700 \pm 30$ & \begin{tabular}{|l|}
$1697-$ \\
1544 \\
\end{tabular} & $E$ \\
\hline 5 & $\begin{array}{l}\text { B-South } \\
\text { Center }\end{array}$ & Simushir & $\begin{array}{l}\text { Vodopadnaya } \\
2\end{array}$ & Unit 1, Level 7, bottom & $\mathrm{Ch}$ & $\begin{array}{l}\text { KBP } \\
1536 \\
\end{array}$ & \begin{tabular}{|l|} 
OS- \\
97997 \\
\end{tabular} & $1700 \pm 20$ & \begin{tabular}{|l|}
$1693-$ \\
1552 \\
\end{tabular} & $E$ \\
\hline 5 & $\begin{array}{l}\text { B-South } \\
\text { Center }\end{array}$ & Simushir & $\begin{array}{l}\text { Vodopadnaya } \\
2\end{array}$ & $\begin{array}{l}\text { Unit 4, Level 13, burned } \\
\text { rafter, } 85 \mathrm{cmbl}\end{array}$ & $\mathrm{Ch}$ & $\begin{array}{l}\text { KBP } \\
1550\end{array}$ & \begin{tabular}{|l|} 
OS- \\
67586 \\
\end{tabular} & $1690 \pm 30$ & \begin{tabular}{|l|}
$1694-$ \\
1534 \\
\end{tabular} & $E$ \\
\hline 5 & $\begin{array}{l}\text { B-South } \\
\text { Center }\end{array}$ & Simushir & $\begin{array}{l}\text { Vodopadnaya } \\
2\end{array}$ & $\begin{array}{l}\text { Unit 1; North Wall, } 62 \\
\text { cmbs, below tephra }\end{array}$ & $\mathrm{Ch}$ & $\begin{array}{l}\text { KBP } \\
1831 \\
\end{array}$ & \begin{tabular}{|l|} 
OS- \\
67492 \\
\end{tabular} & $1650 \pm 30$ & \begin{tabular}{|l|}
$1687-$ \\
1418 \\
\end{tabular} & $E$ \\
\hline 5 & $\begin{array}{l}\text { B-South } \\
\text { Center }\end{array}$ & Simushir & $\begin{array}{l}\text { Vodopadnaya } \\
2\end{array}$ & Test Pit 3, Level 6 & $\mathrm{Ch}$ & $\begin{array}{l}\text { KBP } \\
0581 \\
\end{array}$ & \begin{tabular}{|l|} 
OS- \\
59201 \\
\end{tabular} & $1650 \pm 25$ & \begin{tabular}{|l|}
$1615-$ \\
1422 \\
\end{tabular} & $E$ \\
\hline 5 & $\begin{array}{l}\text { B-South } \\
\text { Center }\end{array}$ & Simushir & $\begin{array}{l}\text { Vodopadnaya } \\
2\end{array}$ & $\begin{array}{l}\text { Test Pit 2, hearth, } 45-52 \\
\text { cmbs }\end{array}$ & $\mathrm{Ch}$ & $\begin{array}{l}\text { KBP } \\
0474\end{array}$ & \begin{tabular}{|l|} 
OS- \\
59197 \\
\end{tabular} & $1600 \pm 25$ & \begin{tabular}{|l|}
$1546-$ \\
1414 \\
\end{tabular} & D \\
\hline 5 & $\begin{array}{l}\text { B-South } \\
\text { Center }\end{array}$ & Simushir & $\begin{array}{l}\text { Vodopadnaya } \\
2\end{array}$ & $\begin{array}{l}\text { Unit 3, North } 48-49 \text { cmbs, } 1 \\
\text { mm below tephra, Strat }\end{array}$ & $\mathrm{Ch}$ & $\begin{array}{l}\text { KBP } \\
1824 \\
\end{array}$ & \begin{tabular}{|l|} 
OS- \\
67617 \\
\end{tabular} & $1570 \pm 25$ & $\begin{array}{l}1530- \\
1404 \\
\end{array}$ & $E$ \\
\hline
\end{tabular}




\begin{tabular}{|c|c|c|c|c|c|c|c|c|c|c|}
\hline & & & & 1 & & & & & & \\
\hline 5 & $\begin{array}{l}\text { B-South } \\
\text { Center }\end{array}$ & Simushir & $\begin{array}{l}\text { Vodopadnaya } \\
2\end{array}$ & $\begin{array}{l}\text { Probe Survey, house pit } \\
\text { probe } 07 \text { (GPS 385) }\end{array}$ & $\mathrm{Ch}$ & $\begin{array}{l}\text { KBP } \\
1947 \\
\end{array}$ & $\begin{array}{l}\text { OS- } \\
95623 \\
\end{array}$ & $1480 \pm 25$ & $\begin{array}{l}1406- \\
1313\end{array}$ & $E$ \\
\hline 5 & $\begin{array}{l}\text { B-South } \\
\text { Center }\end{array}$ & Simushir & $\begin{array}{l}\text { Vodopadnaya } \\
2\end{array}$ & Unit 4, Level 10, $59 \mathrm{~cm}$ & $\mathrm{Ch}$ & $\begin{array}{l}\text { KBP } \\
1454\end{array}$ & $\begin{array}{l}\text { OS- } \\
67269\end{array}$ & $1470 \pm 30$ & $\begin{array}{l}1405- \\
1305\end{array}$ & $E$ \\
\hline 5 & $\begin{array}{l}\text { B-South } \\
\text { Center }\end{array}$ & Simushir & $\begin{array}{l}\text { Vodopadnaya } \\
2\end{array}$ & Unit 4, Level 8, bulk & $\mathrm{Ch}$ & $\begin{array}{l}\text { KBP } \\
1402 \\
\end{array}$ & $\begin{array}{l}\text { OS- } \\
97904\end{array}$ & $1460 \pm 30$ & $\begin{array}{l}1398- \\
1302\end{array}$ & $E$ \\
\hline 5 & $\begin{array}{l}\text { B-South } \\
\text { Center }\end{array}$ & Simushir & $\begin{array}{l}\text { Vodopadnaya } \\
2\end{array}$ & $\begin{array}{l}\text { Test Pit 3, Level 3, above } \\
\text { and in midden layers }\end{array}$ & $\mathrm{Ch}$ & $\begin{array}{l}\text { KBP } \\
0487\end{array}$ & $\begin{array}{l}\text { OS- } \\
97889\end{array}$ & $1360 \pm 20$ & $\begin{array}{l}1306- \\
1271\end{array}$ & $E$ \\
\hline 5 & $\begin{array}{l}\text { B-South } \\
\text { Center }\end{array}$ & Simushir & $\begin{array}{l}\text { Vodopadnaya } \\
2\end{array}$ & Unit 1, Level 2 & $\mathrm{Ch}$ & $\begin{array}{l}\text { KBP } \\
1231\end{array}$ & $\begin{array}{l}\text { OS- } \\
97900\end{array}$ & $1310 \pm 30$ & $\begin{array}{l}1295- \\
1181\end{array}$ & $E$ \\
\hline 5 & $\begin{array}{l}\text { B-South } \\
\text { Center }\end{array}$ & Simushir & $\begin{array}{l}\text { Vodopadnaya } \\
2\end{array}$ & $\begin{array}{l}\text { Test Pit 3, Level 4, directly } \\
\text { above tephra at } 75 \mathrm{cmbs} \text {, } \\
\text { SE corner }\end{array}$ & $\mathrm{Ch}$ & $\begin{array}{l}\text { KBP } \\
0574\end{array}$ & $\begin{array}{l}\text { OS- } \\
97893\end{array}$ & $1310 \pm 25$ & $\begin{array}{l}1293- \\
1183\end{array}$ & $E$ \\
\hline 5 & $\begin{array}{l}\text { B-South } \\
\text { Center }\end{array}$ & Simushir & $\begin{array}{l}\text { Vodopadnaya } \\
2\end{array}$ & $\begin{array}{l}\text { Test Pit 3, Level 3, inside } \\
\text { pot at base of level } 3\end{array}$ & $\mathrm{Ch}$ & $\begin{array}{l}\text { KBP } \\
0483 \\
\end{array}$ & $\begin{array}{l}\text { OS- } \\
59421\end{array}$ & $1300 \pm 30$ & $\begin{array}{l}1291- \\
1181\end{array}$ & $E$ \\
\hline 5 & $\begin{array}{l}\text { B-South } \\
\text { Center }\end{array}$ & Simushir & $\begin{array}{l}\text { Vodopadnaya } \\
2\end{array}$ & $\begin{array}{l}\text { Unit 3, Level 3, } 120 \mathrm{cmbd} \\
\text { (bottom cultural level) }\end{array}$ & $\mathrm{Ch}$ & $\begin{array}{l}\text { KBP } \\
1329 \\
\end{array}$ & $\begin{array}{l}\text { OS- } \\
97903 \\
\end{array}$ & $1300 \pm 30$ & $\begin{array}{l}1291- \\
1181\end{array}$ & $E$ \\
\hline 5 & $\begin{array}{l}\text { B-South } \\
\text { Center }\end{array}$ & Simushir & $\begin{array}{l}\text { Vodopadnaya } \\
2\end{array}$ & $\begin{array}{l}\text { Unit 1, South Wall, } 42 \\
\text { cmbs, below cinders }\end{array}$ & $\mathrm{Ch}$ & $\begin{array}{l}\text { KBP } \\
1826 \\
\end{array}$ & $\begin{array}{l}\text { OS- } \\
67471 \\
\end{array}$ & $1280 \pm 25$ & $\begin{array}{l}1280- \\
1180\end{array}$ & $E$ \\
\hline 5 & $\begin{array}{l}\text { B-South } \\
\text { Center }\end{array}$ & Simushir & $\begin{array}{l}\text { Vodopadnaya } \\
2\end{array}$ & Test Pit 3, Level 5 & $\mathrm{Ch}$ & $\begin{array}{l}\text { KBP } \\
0582\end{array}$ & $\begin{array}{l}\text { OS- } \\
59202\end{array}$ & $1260 \pm 30$ & $\begin{array}{l}1282- \\
1086\end{array}$ & $E$ \\
\hline 5 & $\begin{array}{l}\text { B-South } \\
\text { Center }\end{array}$ & Simushir & $\begin{array}{l}\text { Vodopadnaya } \\
2\end{array}$ & Unit 4, Level 5 & $\mathrm{Ch}$ & $\begin{array}{l}\text { KBP } \\
1565\end{array}$ & $\begin{array}{l}\text { OS- } \\
97998\end{array}$ & $1110 \pm 35$ & $1173-933$ & $E$ \\
\hline 5 & $\begin{array}{l}\text { B-South } \\
\text { Center }\end{array}$ & Simushir & $\begin{array}{l}\text { Vodopadnaya } \\
2\end{array}$ & Unit 3, Level 2 & $\mathrm{Ch}$ & $\begin{array}{l}\text { KBP } \\
1246 \\
\end{array}$ & $\begin{array}{l}\text { OS- } \\
97902\end{array}$ & $1110 \pm 30$ & $1072-937$ & $E$ \\
\hline 5 & $\begin{array}{l}\text { B-South } \\
\text { Center }\end{array}$ & Simushir & $\begin{array}{l}\text { Vodopadnaya } \\
2\end{array}$ & Unit 4, Level 11, $77 \mathrm{cmbd}$ & $\mathrm{Ch}$ & $\begin{array}{l}\text { KBP } \\
1530 \\
\end{array}$ & $\begin{array}{l}\text { OS- } \\
67616 \\
\end{array}$ & $1100 \pm 30$ & $1064-937$ & $E$ \\
\hline 5 & $\begin{array}{l}\text { B-South } \\
\text { Center }\end{array}$ & Simushir & $\begin{array}{l}\text { Vodopadnaya } \\
2\end{array}$ & $\begin{array}{l}\text { Unit } 3 \text { North, Strat 1, 22-25 } \\
\text { cmbs cinders }\end{array}$ & $\mathrm{Ch}$ & $\begin{array}{l}\text { KBP } \\
1832 \\
\end{array}$ & $\begin{array}{l}\text { OS- } \\
67588 \\
\end{array}$ & $1100 \pm 30$ & $1064-937$ & $E$ \\
\hline 5 & $\begin{array}{l}\text { B-South } \\
\text { Center }\end{array}$ & Simushir & $\begin{array}{l}\text { Vodopadnaya } \\
2\end{array}$ & Test Pit 3, Level 2 & $\mathrm{Ch}$ & $\begin{array}{l}\text { KBP } \\
0479 \\
\end{array}$ & $\begin{array}{l}\text { OS- } \\
59381\end{array}$ & $1090 \pm 25$ & $1058-937$ & $D$ \\
\hline 5 & $\begin{array}{l}\text { B-South } \\
\text { Center }\end{array}$ & Simushir & $\begin{array}{l}\text { Vodopadnaya } \\
2\end{array}$ & $\begin{array}{l}\text { Unit 4, Level 10, } 60 \mathrm{cmbl} \text {, } \\
\text { inside house wall }\end{array}$ & $\mathrm{Ch}$ & $\begin{array}{l}\text { KBP } \\
1534 \\
\end{array}$ & $\begin{array}{l}\text { OS- } \\
97907\end{array}$ & $1070 \pm 25$ & $1054-930$ & $E$ \\
\hline
\end{tabular}




\begin{tabular}{|c|c|c|c|c|c|c|c|c|c|c|}
\hline 5 & $\begin{array}{l}\text { B-South } \\
\text { Center }\end{array}$ & Simushir & $\begin{array}{l}\text { Vodopadnaya } \\
2\end{array}$ & Unit 2, Level 2 & $\mathrm{Ch}$ & $\begin{array}{l}\text { KBP } \\
1237\end{array}$ & $\begin{array}{l}\text { OS- } \\
97901\end{array}$ & $1060 \pm 20$ & $1049-928$ & $E$ \\
\hline 5 & $\begin{array}{l}\text { B-South } \\
\text { Center }\end{array}$ & Simushir & $\begin{array}{l}\text { Vodopadnaya } \\
2\end{array}$ & $\begin{array}{l}\text { Probe Survey, house pit } \\
\text { probe } 01 \text { (GPS 379) }\end{array}$ & $\mathrm{Ch}$ & $\begin{array}{l}\text { KBP } \\
1939 \\
\end{array}$ & $\begin{array}{l}\text { OS- } \\
95620\end{array}$ & $1050 \pm 40$ & $1059-914$ & $E$ \\
\hline 5 & $\begin{array}{l}\text { B-South } \\
\text { Center }\end{array}$ & Simushir & $\begin{array}{l}\text { Vodopadnaya } \\
2\end{array}$ & $\begin{array}{l}\text { Probe Survey, house pit } \\
\text { probe } 04 \text { (GPS 382) }\end{array}$ & $\mathrm{Ch}$ & $\begin{array}{l}\text { KBP } \\
1946\end{array}$ & $\begin{array}{l}\text { OS- } \\
95622\end{array}$ & $945 \pm 25$ & $924-795$ & $E$ \\
\hline 5 & $\begin{array}{l}\text { B-South } \\
\text { Center }\end{array}$ & Simushir & $\begin{array}{l}\text { Vodopadnaya } \\
2\end{array}$ & $\begin{array}{l}\text { Probe Survey, house pit } \\
\text { probe } 10 \text { (GPS 388) }\end{array}$ & $\mathrm{Ch}$ & $\begin{array}{l}\text { KBP } \\
1940\end{array}$ & $\begin{array}{l}\text { OS- } \\
95621\end{array}$ & $430 \pm 25$ & $524-342$ & $E$ \\
\hline 6 & $\begin{array}{l}\text { B-South } \\
\text { Center }\end{array}$ & Ushishir & Ryponkicha 1 & Unit 1, S Trench, $114 \mathrm{cmbl}$ & $\mathrm{Ch}$ & $\begin{array}{l}\text { KBP } \\
1884 \\
\end{array}$ & $\begin{array}{l}\text { OS- } \\
67329 \\
\end{array}$ & $1390 \pm 30$ & $\begin{array}{l}1348- \\
1277 \\
\end{array}$ & $\mathrm{C}$ \\
\hline 6 & $\begin{array}{l}\text { B-South } \\
\text { Center }\end{array}$ & Ushishir & Ryponkicha 1 & $\begin{array}{l}\text { Test Pit 2, Level } 3,30 \text { - } \\
45 \mathrm{cmbs} \text {, from bulk midden } \\
\text { sample } 1 / 4 \text { " fraction }\end{array}$ & $\mathrm{Ch}$ & $\begin{array}{l}\text { KBP } \\
0983\end{array}$ & $\begin{array}{l}\text { OS- } \\
59419\end{array}$ & $1130 \pm 25$ & $1173-963$ & $E$ \\
\hline 6 & $\begin{array}{l}\text { B-South } \\
\text { Center }\end{array}$ & Ushishir & Ryponkicha 1 & $\begin{array}{l}\text { Test Pit 2, Level 1, 0-19 } \\
\text { cmbs, charcoal }\end{array}$ & $\mathrm{Ch}$ & $\begin{array}{l}\text { KBP } \\
0630\end{array}$ & $\begin{array}{l}\text { OS- } \\
59418\end{array}$ & $1090 \pm 30$ & $1058-936$ & $E$ \\
\hline 6 & $\begin{array}{l}\text { B-South } \\
\text { Center }\end{array}$ & Ushishir & Ryponkicha 1 & $\begin{array}{l}\text { Probe Survey, Probe } 6, \\
\text { house pit 187, GPS 476, } \\
\text { charcoal }\end{array}$ & $\mathrm{Ch}$ & $\begin{array}{l}\text { KBP } \\
2118\end{array}$ & $\begin{array}{l}\text { OS- } \\
98002\end{array}$ & $1000 \pm 25$ & $964-802$ & $E$ \\
\hline 6 & $\begin{array}{l}\text { B-South } \\
\text { Center }\end{array}$ & Ushishir & Ryponkicha 1 & Unit 1, Level 4, bulk & $\mathrm{Ch}$ & $\begin{array}{l}\text { KBP } \\
1880\end{array}$ & $\begin{array}{l}\text { OS- } \\
98016\end{array}$ & $975 \pm 25$ & $936-796$ & $E$ \\
\hline 6 & $\begin{array}{l}\text { B-South } \\
\text { Center }\end{array}$ & Ushishir & Ryponkicha 1 & $\begin{array}{l}\text { Probe Survey, Probe } 2, \\
\text { house pit } 185, \text { GPS } 472, \\
\text { charcoal above pumice }\end{array}$ & $\mathrm{Ch}$ & $\begin{array}{l}\text { KBP } \\
2114\end{array}$ & $\begin{array}{l}\text { OS- } \\
98001\end{array}$ & $795 \pm 25$ & $745-675$ & $E$ \\
\hline 6 & $\begin{array}{l}\text { B-South } \\
\text { Center }\end{array}$ & Ushishir & Ryponkicha 2 & V131 charcoal & $\mathrm{Ch}$ & $\begin{array}{l}\text { KBP } \\
4215\end{array}$ & $\begin{array}{l}\text { OS- } \\
95663\end{array}$ & $1300 \pm 25$ & $\begin{array}{l}1289- \\
1182\end{array}$ & $E$ \\
\hline 6 & $\begin{array}{l}\text { B-South } \\
\text { Center }\end{array}$ & Ushishir & Ryponkicha 2 & V133 charcoal & $\mathrm{Ch}$ & $\begin{array}{l}\text { KBP } \\
4214\end{array}$ & $\begin{array}{l}\text { OS- } \\
80150\end{array}$ & $430 \pm 25$ & $524-342$ & $E$ \\
\hline 6 & $\begin{array}{l}\text { B-South } \\
\text { Center }\end{array}$ & Ushishir & $\begin{array}{l}\text { Ryponkicha } \\
\text { South }\end{array}$ & "JBII" excavation; 84-85 cm & $\mathrm{Ch}$ & $\begin{array}{l}\text { KBP } \\
0987\end{array}$ & $\begin{array}{l}\text { OS- } \\
80149\end{array}$ & $615 \pm 25$ & $655-550$ & $\mathrm{C}$ \\
\hline 6 & $\begin{array}{l}\text { B-South } \\
\text { Center }\end{array}$ & Ushishir & Yankicha 1 & $\begin{array}{l}\text { Test Pit 1, 50-60 cmbs, } \\
\text { house pit level }\end{array}$ & $\mathrm{Ch}$ & $\begin{array}{l}\text { KBP } \\
0619\end{array}$ & $\begin{array}{l}\text { OS- } \\
59420\end{array}$ & $100 \pm 25$ & $264-23$ & $\mathrm{C}$ \\
\hline 6 & $\begin{array}{l}\text { B-South } \\
\text { Center }\end{array}$ & Ushishir & Yankicha 2 & $\begin{array}{l}\text { Probe Survey, house pit 5, } \\
\text { below tephra }\end{array}$ & $\mathrm{Ch}$ & $\begin{array}{l}\text { KBP } \\
1888 \\
\end{array}$ & $\begin{array}{l}\text { OS- } \\
98000\end{array}$ & $305 \pm 25$ & $458-301$ & $\mathrm{C}$ \\
\hline 6 & B-South & Ushishir & Yankicha 2 & Probe Survey, house pit 3, & $\mathrm{Ch}$ & KBP & OS- & $35 \pm 20$ & $245-35$ & $E$ \\
\hline
\end{tabular}




\begin{tabular}{|c|c|c|c|c|c|c|c|c|c|c|}
\hline & Center & & & $20 \mathrm{cmbs}$ & & 1886 & 97999 & & & \\
\hline 7 & $\begin{array}{l}\text { B-South } \\
\text { Center }\end{array}$ & Rasshua & Rasshua 1 & $\begin{array}{l}\text { Test Pit 1A, excavation } \\
\text { profile, "npcs" \#7 shell and } \\
\text { charcoal layer }\end{array}$ & $\mathrm{Ch}$ & $\begin{array}{l}\text { KBP } \\
4010\end{array}$ & $\begin{array}{l}\text { OS- } \\
79602\end{array}$ & $3450 \pm 30$ & $\begin{array}{l}3829- \\
3637\end{array}$ & $\mathrm{C}$ \\
\hline 7 & $\begin{array}{l}\text { B-South } \\
\text { Center }\end{array}$ & Rasshua & Rasshua 1 & Test Pit 1A, Level 8 & $\mathrm{Ch}$ & $\begin{array}{l}\text { KBP } \\
3868\end{array}$ & $\begin{array}{l}\text { OS- } \\
79743\end{array}$ & $3280 \pm 35$ & $\begin{array}{l}3585- \\
3409\end{array}$ & $\mathrm{E}$ \\
\hline 7 & $\begin{array}{l}\text { B-South } \\
\text { Center }\end{array}$ & Rasshua & Rasshua 1 & $\begin{array}{l}\text { Erosion face, Section 1B: } \\
\text { immediately above It. grey } \\
\text { fine tephra }\end{array}$ & $\mathrm{Ch}$ & $\begin{array}{l}\text { KBP } \\
1900\end{array}$ & $\begin{array}{l}\text { OS- } \\
67143\end{array}$ & $3260 \pm 30$ & $\begin{array}{l}3565- \\
3403\end{array}$ & $\mathrm{E}$ \\
\hline 7 & $\begin{array}{l}\text { B-South } \\
\text { Center }\end{array}$ & Rasshua & Rasshua 1 & $\begin{array}{l}\text { Test Pit 2, excavation } \\
\text { profile }\end{array}$ & $\mathrm{Ch}$ & $\begin{array}{l}\text { KBP } \\
4104\end{array}$ & $\begin{array}{l}\text { OS- } \\
79665\end{array}$ & $2860 \pm 25$ & $\begin{array}{l}3064- \\
2884\end{array}$ & $\mathrm{E}$ \\
\hline 7 & $\begin{array}{l}\text { B-South } \\
\text { Center }\end{array}$ & Rasshua & Rasshua 1 & $\begin{array}{l}\text { Test Pit 2, excavation } \\
\text { profile }\end{array}$ & $\mathrm{Ch}$ & $\begin{array}{l}\text { KBP } \\
4106 \\
\end{array}$ & $\begin{array}{l}\text { OS- } \\
79667\end{array}$ & $2660 \pm 25$ & $\begin{array}{l}2843- \\
2744 \\
\end{array}$ & $\mathrm{E}$ \\
\hline 7 & $\begin{array}{l}\text { B-South } \\
\text { Center }\end{array}$ & Rasshua & Rasshua 1 & $\begin{array}{l}\text { Test Pit 2, Level } 8 \mathrm{~A}, \\
\text { charcoal concentration }\end{array}$ & $\mathrm{Ch}$ & $\begin{array}{l}\text { KBP } \\
3996\end{array}$ & $\begin{array}{l}\text { OS- } \\
79896\end{array}$ & $2640 \pm 30$ & $\begin{array}{l}2842- \\
2735\end{array}$ & $\mathrm{E}$ \\
\hline 7 & $\begin{array}{l}\text { B-South } \\
\text { Center }\end{array}$ & Rasshua & Rasshua 1 & $\begin{array}{l}\text { Erosion face, Section 1B: } \\
\text { Epi-Jomon layer, just below } \\
\text { fine lt. grey tephra }\end{array}$ & $\mathrm{Ch}$ & $\begin{array}{l}\text { KBP } \\
1901\end{array}$ & $\begin{array}{l}\text { OS- } \\
67330\end{array}$ & $2570 \pm 30$ & $\begin{array}{l}2758- \\
2508\end{array}$ & $E$ \\
\hline 7 & $\begin{array}{l}\text { B-South } \\
\text { Center }\end{array}$ & Rasshua & Rasshua 1 & $\begin{array}{l}\text { Test Pit 1B, excavation } \\
\text { profile sample }\end{array}$ & $\mathrm{W}$ & $\begin{array}{l}\text { KBP } \\
4136\end{array}$ & $\begin{array}{l}\text { OS- } \\
79604\end{array}$ & $2490 \pm 25$ & $\begin{array}{l}2723- \\
2473 \\
\end{array}$ & $\mathrm{E}$ \\
\hline 7 & $\begin{array}{l}\text { B-South } \\
\text { Center }\end{array}$ & Rasshua & Rasshua 1 & $\begin{array}{l}\text { Test Pit 2, excavation } \\
\text { profile }\end{array}$ & $\mathrm{Ch}$ & $\begin{array}{l}\text { KBP } \\
4105 \\
\end{array}$ & $\begin{array}{l}\text { OS- } \\
79666\end{array}$ & $2480 \pm 35$ & $\begin{array}{l}2724- \\
2380\end{array}$ & $E$ \\
\hline 7 & $\begin{array}{l}\text { B-South } \\
\text { Center }\end{array}$ & Rasshua & Rasshua 1 & $\begin{array}{l}\text { Erosion face, Section 1B: } \\
\text { Epi-Jomon cultural layer, } \\
\text { ca. } 5 \mathrm{~cm} \text { above lt. grey } \\
\text { tephra }\end{array}$ & $\mathrm{Ch}$ & $\begin{array}{l}\text { KBP } \\
1899\end{array}$ & $\begin{array}{l}\text { OS- } \\
67086\end{array}$ & $2430 \pm 25$ & $\begin{array}{l}2697- \\
2355\end{array}$ & B \\
\hline 7 & $\begin{array}{l}\text { B-South } \\
\text { Center }\end{array}$ & Rasshua & Rasshua 1 & $\begin{array}{l}\text { Test Pit 2, excavation } \\
\text { profile }\end{array}$ & $\mathrm{Ch}$ & $\begin{array}{l}\text { KBP } \\
4103\end{array}$ & $\begin{array}{l}\text { OS- } \\
79720\end{array}$ & $2430 \pm 25$ & $\begin{array}{l}2697- \\
2355\end{array}$ & $\mathrm{E}$ \\
\hline 7 & $\begin{array}{l}\text { B-South } \\
\text { Center }\end{array}$ & Rasshua & Rasshua 1 & $\begin{array}{l}\text { Test Pit 1A, excavation } \\
\text { profile, "npcs" \#14 }\end{array}$ & $\mathrm{Ch}$ & $\begin{array}{l}\text { KBP } \\
4017\end{array}$ & $\begin{array}{l}\text { OS- } \\
79598\end{array}$ & $2260 \pm 30$ & $\begin{array}{l}2346- \\
2158\end{array}$ & $E$ \\
\hline 7 & $\begin{array}{l}\text { B-South } \\
\text { Center }\end{array}$ & Rasshua & Rasshua 1 & Test Pit 2, Level 4 & $\mathrm{Ch}$ & $\begin{array}{l}\text { KBP } \\
3650\end{array}$ & $\begin{array}{l}\text { OS- } \\
79863\end{array}$ & $2250 \pm 25$ & $\begin{array}{l}2341- \\
2158\end{array}$ & $E$ \\
\hline 7 & $\begin{array}{l}\text { B-South } \\
\text { Center }\end{array}$ & Rasshua & Rasshua 1 & Test Pit 1B, level 3J & $\mathrm{Ch}$ & $\begin{array}{l}\text { KBP } \\
4155\end{array}$ & $\begin{array}{l}\text { OS- } \\
79859\end{array}$ & $2230 \pm 30$ & $\begin{array}{l}2333- \\
2153\end{array}$ & $\mathrm{E}$ \\
\hline
\end{tabular}




\begin{tabular}{|c|c|c|c|c|c|c|c|c|c|c|}
\hline 7 & $\begin{array}{l}\text { B-South } \\
\text { Center }\end{array}$ & Rasshua & Rasshua 1 & $\begin{array}{l}\text { Test Pit 2, excavation } \\
\text { profile }\end{array}$ & $\mathrm{Ch}$ & $\begin{array}{l}\text { KBP } \\
4102\end{array}$ & $\begin{array}{l}\text { OS- } \\
79671\end{array}$ & $2210 \pm 25$ & $\begin{array}{l}2313- \\
2151\end{array}$ & $E$ \\
\hline 7 & $\begin{array}{l}\text { B-South } \\
\text { Center }\end{array}$ & Rasshua & Rasshua 1 & Test Pit 2, Level 7B & $\mathrm{Ch}$ & $\begin{array}{l}\text { KBP } \\
3839\end{array}$ & $\begin{array}{l}\text { OS- } \\
79868\end{array}$ & $2160 \pm 35$ & $\begin{array}{l}2308- \\
2046\end{array}$ & $E$ \\
\hline 7 & $\begin{array}{l}\text { B-South } \\
\text { Center }\end{array}$ & Rasshua & Rasshua 1 & $\begin{array}{l}\text { Probe Survey: house pit } \\
\text { N67 (GPS 258) }\end{array}$ & Ch & $\begin{array}{l}\text { KBP } \\
4044\end{array}$ & $\begin{array}{l}\text { OS- } \\
80017\end{array}$ & $2130 \pm 25$ & $\begin{array}{l}2296- \\
2006\end{array}$ & $E$ \\
\hline 7 & $\begin{array}{l}\text { B-South } \\
\text { Center }\end{array}$ & Rasshua & Rasshua 1 & $\begin{array}{l}\text { Test Pit 2, excavation } \\
\text { profile }\end{array}$ & Ch & $\begin{array}{l}\text { KBP } \\
4100\end{array}$ & $\begin{array}{l}\text { OS- } \\
79670\end{array}$ & $2110 \pm 25$ & $\begin{array}{l}2146- \\
2003\end{array}$ & $E$ \\
\hline 7 & $\begin{array}{l}\text { B-South } \\
\text { Center }\end{array}$ & Rasshua & Rasshua 1 & $\begin{array}{l}\text { Probe Survey: house pit } \\
\text { N67 (GPS 258) }\end{array}$ & Ch & $\begin{array}{l}\text { KBP } \\
4046\end{array}$ & $\begin{array}{l}\text { OS- } \\
80018\end{array}$ & $2080 \pm 25$ & $\begin{array}{l}2125- \\
1990\end{array}$ & $E$ \\
\hline 7 & $\begin{array}{l}\text { B-South } \\
\text { Center }\end{array}$ & Rasshua & Rasshua 1 & $\begin{array}{l}\text { Test Pit } 2 \text {, excavation } \\
\text { profile }\end{array}$ & Ch & $\begin{array}{l}\text { KBP } \\
4099\end{array}$ & $\begin{array}{l}\text { OS- } \\
79669\end{array}$ & $2080 \pm 25$ & $\begin{array}{l}2125- \\
1990\end{array}$ & $E$ \\
\hline 7 & $\begin{array}{l}\text { B-South } \\
\text { Center }\end{array}$ & Rasshua & Rasshua 1 & Test Pit 2, Level 7A & $\mathrm{Ch}$ & $\begin{array}{l}\text { KBP } \\
3828 \\
\end{array}$ & $\begin{array}{l}\text { OS- } \\
79867\end{array}$ & $2040 \pm 30$ & $\begin{array}{l}2111- \\
1904\end{array}$ & $E$ \\
\hline 7 & $\begin{array}{l}\text { B-South } \\
\text { Center }\end{array}$ & Rasshua & Rasshua 1 & Test Pit 2, Level 7A & $\mathrm{Ch}$ & $\begin{array}{l}\text { KBP } \\
3827\end{array}$ & $\begin{array}{l}\text { OS- } \\
79866\end{array}$ & $2040 \pm 25$ & $\begin{array}{l}2109- \\
1926\end{array}$ & $E$ \\
\hline 7 & $\begin{array}{l}\text { B-South } \\
\text { Center }\end{array}$ & Rasshua & Rasshua 1 & Test Pit 2, Level 6 & Ch & $\begin{array}{l}\text { KBP } \\
3820\end{array}$ & $\begin{array}{l}\text { OS- } \\
79865\end{array}$ & $2020 \pm 30$ & $\begin{array}{l}2056- \\
1892\end{array}$ & $E$ \\
\hline 7 & $\begin{array}{l}\text { B-South } \\
\text { Center }\end{array}$ & Rasshua & Rasshua 1 & Test Pit 2, Level 5 & Ch & $\begin{array}{l}\text { KBP } \\
3652\end{array}$ & $\begin{array}{l}\text { OS- } \\
79864\end{array}$ & $2010 \pm 30$ & $\begin{array}{l}2041- \\
1885\end{array}$ & $E$ \\
\hline 7 & $\begin{array}{l}\text { B-South } \\
\text { Center }\end{array}$ & Rasshua & Rasshua 1 & $\begin{array}{l}\text { Erosion face, Section } 1 \mathrm{~A}, \\
25-30 \mathrm{~cm} \text {, just above } \\
\text { orange f-ms yellow brown } \\
\text { tephra }\end{array}$ & $\mathrm{Ch}$ & $\begin{array}{l}\text { KBP } \\
1907\end{array}$ & $\begin{array}{l}\text { OS- } \\
67131\end{array}$ & $1990 \pm 30$ & $\begin{array}{l}1998- \\
1878\end{array}$ & B \\
\hline 7 & $\begin{array}{l}\text { B-South } \\
\text { Center }\end{array}$ & Rasshua & Rasshua 1 & $\begin{array}{l}\text { Test Pit 1A, excavation } \\
\text { profile, "npcs" \#10 }\end{array}$ & Ch & $\begin{array}{l}\text { KBP } \\
4013\end{array}$ & $\begin{array}{l}\text { OS- } \\
79594\end{array}$ & $1970 \pm 30$ & $\begin{array}{l}1994- \\
1865\end{array}$ & $E$ \\
\hline 7 & $\begin{array}{l}\text { B-South } \\
\text { Center }\end{array}$ & Rasshua & Rasshua 1 & $\begin{array}{l}\text { Test Pit 1A, excavation } \\
\text { profile, "npcs" \#13 }\end{array}$ & $\mathrm{Ch}$ & $\begin{array}{l}\text { KBP } \\
4016\end{array}$ & $\begin{array}{l}\text { OS- } \\
79597\end{array}$ & $1970 \pm 25$ & $\begin{array}{l}1989- \\
1872\end{array}$ & $E$ \\
\hline 7 & $\begin{array}{l}\text { B-South } \\
\text { Center }\end{array}$ & Rasshua & Rasshua 1 & $\begin{array}{l}\text { Test Pit 2, excavation } \\
\text { profile }\end{array}$ & Ch & $\begin{array}{l}\text { KBP } \\
4097\end{array}$ & $\begin{array}{l}\text { OS- } \\
79668\end{array}$ & $1950 \pm 25$ & $\begin{array}{l}1970- \\
1825 \\
\end{array}$ & $E$ \\
\hline 7 & $\begin{array}{l}\text { B-South } \\
\text { Center }\end{array}$ & Rasshua & Rasshua 1 & $\begin{array}{l}\text { Test Pit 1A, excavation } \\
\text { profile, "npcs" \#8 }\end{array}$ & Ch & $\begin{array}{l}\text { KBP } \\
4011 \\
\end{array}$ & $\begin{array}{l}\text { OS- } \\
79603\end{array}$ & $1940 \pm 30$ & $\begin{array}{l}1969- \\
1821 \\
\end{array}$ & $E$ \\
\hline 7 & $\begin{array}{l}\text { B-South } \\
\text { Center }\end{array}$ & Rasshua & Rasshua 1 & $\begin{array}{l}\text { Test Pit 1A, excavation } \\
\text { profile, "npcs" \#2 }\end{array}$ & $\mathrm{Ch}$ & $\begin{array}{l}\text { KBP } \\
4005\end{array}$ & $\begin{array}{l}\text { OS- } \\
79600\end{array}$ & $1930 \pm 25$ & $\begin{array}{l}1929- \\
1822\end{array}$ & $E$ \\
\hline
\end{tabular}




\begin{tabular}{|c|c|c|c|c|c|c|c|c|c|c|}
\hline 7 & $\begin{array}{l}\text { B-South } \\
\text { Center }\end{array}$ & Rasshua & Rasshua 1 & $\begin{array}{l}\text { Probe Survey: house pit } \\
\text { N70 (GPS 248) }\end{array}$ & $\mathrm{Ch}$ & $\begin{array}{l}\text { KBP } \\
4030\end{array}$ & $\begin{array}{l}\text { OS- } \\
80016\end{array}$ & $1920 \pm 30$ & $\begin{array}{l}1948- \\
1746\end{array}$ & $E$ \\
\hline 7 & $\begin{array}{l}\text { B-South } \\
\text { Center }\end{array}$ & Rasshua & Rasshua 1 & Test Pit 2, Level 3 & $\mathrm{Ch}$ & $\begin{array}{l}\text { KBP } \\
3658\end{array}$ & $\begin{array}{l}\text { OS- } \\
79862\end{array}$ & $1920 \pm 25$ & $\begin{array}{l}1926- \\
1820\end{array}$ & $E$ \\
\hline 7 & $\begin{array}{l}\text { B-South } \\
\text { Center }\end{array}$ & Rasshua & Rasshua 1 & Test Pit 2, Level 2 & $\mathrm{Ch}$ & $\begin{array}{l}\text { KBP } \\
3580\end{array}$ & $\begin{array}{l}\text { OS- } \\
79861\end{array}$ & $1860 \pm 30$ & $\begin{array}{l}1870- \\
1720\end{array}$ & $\mathrm{E}$ \\
\hline 7 & $\begin{array}{l}\text { B-South } \\
\text { Center }\end{array}$ & Rasshua & Rasshua 1 & Test Pit 1A, Level 5 & $\mathrm{Ch}$ & $\begin{array}{l}\text { KBP } \\
3727\end{array}$ & $\begin{array}{l}\text { OS- } \\
79725\end{array}$ & $1820 \pm 25$ & $\begin{array}{l}1824- \\
1639\end{array}$ & $\mathrm{E}$ \\
\hline 7 & $\begin{array}{l}\text { B-South } \\
\text { Center }\end{array}$ & Rasshua & Rasshua 1 & $\begin{array}{l}\text { Probe Survey: house pit } \\
\text { N70 (GPS 248) }\end{array}$ & $\mathrm{Ch}$ & $\begin{array}{l}\text { KBP } \\
4029\end{array}$ & $\begin{array}{l}\text { OS- } \\
80015\end{array}$ & $1810 \pm 25$ & $\begin{array}{l}1820- \\
1633\end{array}$ & $\mathrm{E}$ \\
\hline 7 & $\begin{array}{l}\text { B-South } \\
\text { Center }\end{array}$ & Rasshua & Rasshua 1 & $\begin{array}{l}\text { Probe Survey: house pit } \\
\text { N40 (GPS 259) }\end{array}$ & $\mathrm{Ch}$ & $\begin{array}{l}\text { KBP } \\
4048\end{array}$ & $\begin{array}{l}\text { OS- } \\
80019\end{array}$ & $1720 \pm 25$ & $\begin{array}{l}1699- \\
1562\end{array}$ & $\mathrm{E}$ \\
\hline 7 & $\begin{array}{l}\text { B-South } \\
\text { Center }\end{array}$ & Rasshua & Rasshua 1 & Test Pit 1A, Level 7 & $\mathrm{Ch}$ & $\begin{array}{l}\text { KBP } \\
3844 b\end{array}$ & $\begin{array}{l}\text { OS- } \\
79741\end{array}$ & $1700 \pm 35$ & $\begin{array}{l}1699- \\
1540\end{array}$ & $\mathrm{E}$ \\
\hline 7 & $\begin{array}{l}\text { B-South } \\
\text { Center }\end{array}$ & Rasshua & Rasshua 1 & $\begin{array}{l}\text { Probe Survey: house pit } \\
\text { N14 (GPS 268) }\end{array}$ & $\mathrm{Ch}$ & $\begin{array}{l}\text { KBP } \\
4061\end{array}$ & $\begin{array}{l}\text { OS- } \\
80020\end{array}$ & $1670 \pm 30$ & $\begin{array}{l}1693- \\
1523\end{array}$ & $\mathrm{E}$ \\
\hline 7 & $\begin{array}{l}\text { B-South } \\
\text { Center }\end{array}$ & Rasshua & Rasshua 1 & $\begin{array}{l}\text { Test Pit 1A, excavation } \\
\text { profile, "npcs" \#11 }\end{array}$ & $\mathrm{Ch}$ & $\begin{array}{l}\text { KBP } \\
4014\end{array}$ & $\begin{array}{l}\text { OS- } \\
79595\end{array}$ & $1280 \pm 25$ & $\begin{array}{l}1280- \\
1180\end{array}$ & $\mathrm{E}$ \\
\hline 7 & $\begin{array}{l}\text { B-South } \\
\text { Center }\end{array}$ & Rasshua & Rasshua 1 & $\begin{array}{l}\text { Test Pit 1A, excavation } \\
\text { profile, "npcs" \#3 }\end{array}$ & $\mathrm{Ch}$ & $\begin{array}{l}\text { KBP } \\
4006\end{array}$ & $\begin{array}{l}\text { OS- } \\
80139\end{array}$ & $1120 \pm 50$ & $1174-936$ & $\mathrm{E}$ \\
\hline 7 & $\begin{array}{l}\text { B-South } \\
\text { Center }\end{array}$ & Rasshua & Rasshua 1 & Test Pit $1 \mathrm{~A}$, base of Level 4 & $\mathrm{Ch}$ & $\begin{array}{l}\mathrm{KBP} \\
3761\end{array}$ & $\begin{array}{l}\text { OS- } \\
79723\end{array}$ & $1100 \pm 35$ & $1168-931$ & $\mathrm{E}$ \\
\hline 7 & $\begin{array}{l}\text { B-South } \\
\text { Center }\end{array}$ & Rasshua & Rasshua 1 & $\begin{array}{l}\text { Test Pit 1A, Level } 3 \text {, base of } \\
\text { midden }\end{array}$ & $\mathrm{Ch}$ & $\begin{array}{l}\text { KBP } \\
3507\end{array}$ & $\begin{array}{l}\text { OS- } \\
79722 \\
\end{array}$ & $1000 \pm 30$ & $967-799$ & $\mathrm{E}$ \\
\hline 7 & $\begin{array}{l}\text { B-South } \\
\text { Center }\end{array}$ & Rasshua & Rasshua 1 & $\begin{array}{l}\text { Test Pit 1A, excavation } \\
\text { profile, "npcs" \#4 }\end{array}$ & $\mathrm{Ch}$ & $\begin{array}{l}\text { KBP } \\
4007\end{array}$ & $\begin{array}{l}\text { OS- } \\
79601\end{array}$ & $1000 \pm 25$ & $964-802$ & $\mathrm{E}$ \\
\hline 7 & $\begin{array}{l}\text { B-South } \\
\text { Center }\end{array}$ & Rasshua & Rasshua 1 & Test Pit 1B, Level 3B & $\mathrm{Ch}$ & $\begin{array}{l}\text { KBP } \\
3600\end{array}$ & $\begin{array}{l}\text { OS- } \\
79726 \\
\end{array}$ & $950 \pm 25$ & $926-796$ & $E$ \\
\hline 7 & $\begin{array}{l}\text { B-South } \\
\text { Center }\end{array}$ & Rasshua & Rasshua 1 & Test Pit 1A, Level 4 midden & $\mathrm{Ch}$ & $\begin{array}{l}\text { KBP } \\
3586\end{array}$ & $\begin{array}{l}\text { OS- } \\
79724\end{array}$ & $935 \pm 25$ & $920-793$ & $\mathrm{E}$ \\
\hline 7 & $\begin{array}{l}\text { B-South } \\
\text { Center }\end{array}$ & Rasshua & Rasshua 1 & Test Pit 1A, Level 7A & $\mathrm{Ch}$ & $\begin{array}{l}\text { KBP } \\
3860\end{array}$ & $\begin{array}{l}\text { OS- } \\
79742 \\
\end{array}$ & $925 \pm 30$ & $925-768$ & $E$ \\
\hline 7 & $\begin{array}{l}\text { B-South } \\
\text { Center }\end{array}$ & Rasshua & Rasshua 1 & Test Pit 1A, Level 4 midden & $\mathrm{Ch}$ & $\begin{array}{l}\text { KBP } \\
3681\end{array}$ & $\begin{array}{l}\text { OS- } \\
98011\end{array}$ & $920 \pm 20$ & $912-789$ & $\mathrm{E}$ \\
\hline
\end{tabular}




\begin{tabular}{|c|c|c|c|c|c|c|c|c|c|c|}
\hline 7 & $\begin{array}{l}\text { B-South } \\
\text { Center }\end{array}$ & Rasshua & Rasshua 1 & Test Pit 1B, Level 3 & $\mathrm{Ch}$ & $\begin{array}{l}\text { KBP } \\
3617\end{array}$ & $\begin{array}{l}\text { OS- } \\
79744\end{array}$ & $915 \pm 30$ & $920-762$ & $E$ \\
\hline 7 & $\begin{array}{l}\text { B-South } \\
\text { Center }\end{array}$ & Rasshua & Rasshua 1 & $\begin{array}{l}\text { Test Pit 1A, Level 2, } \\
\text { charcoal concentration }\end{array}$ & $\mathrm{Ch}$ & $\begin{array}{l}\text { KBP } \\
3497\end{array}$ & $\begin{array}{l}\text { OS- } \\
79721\end{array}$ & $905 \pm 25$ & $913-746$ & $E$ \\
\hline 7 & $\begin{array}{l}\text { B-South } \\
\text { Center }\end{array}$ & Rasshua & Rasshua 1 & $\begin{array}{l}\text { Test Pit 1A, excavation } \\
\text { profile: "npcs" \#12 }\end{array}$ & $\mathrm{Ch}$ & $\begin{array}{l}\text { KBP } \\
4015\end{array}$ & $\begin{array}{l}\text { OS- } \\
79596\end{array}$ & $905 \pm 25$ & $913-746$ & $\mathrm{E}$ \\
\hline 7 & $\begin{array}{l}\text { B-South } \\
\text { Center }\end{array}$ & Rasshua & Rasshua 1 & Test Pit 1A, Level 4 midden & $\mathrm{Ch}$ & $\begin{array}{l}\text { KBP } \\
3709\end{array}$ & $\begin{array}{l}\text { OS- } \\
98012\end{array}$ & $890 \pm 25$ & $907-735$ & $E$ \\
\hline 7 & $\begin{array}{l}\text { B-South } \\
\text { Center }\end{array}$ & Rasshua & Rasshua 1 & Test Pit 1A, Level 4B & $\mathrm{Ch}$ & $\begin{array}{l}\text { KBP } \\
4453\end{array}$ & $\begin{array}{l}\text { OS- } \\
98014\end{array}$ & $890 \pm 20$ & $905-736$ & $\mathrm{E}$ \\
\hline 7 & $\begin{array}{l}\text { B-South } \\
\text { Center }\end{array}$ & Rasshua & Rasshua 1 & Test Pit 1A, Level 3 & $\mathrm{Ch}$ & $\begin{array}{l}\text { KBP } \\
4473\end{array}$ & $\begin{array}{l}\text { OS- } \\
98009\end{array}$ & $860 \pm 20$ & $893-726$ & $E$ \\
\hline 7 & $\begin{array}{l}\text { B-South } \\
\text { Center }\end{array}$ & Rasshua & Rasshua 1 & $\begin{array}{l}\text { Test Pit 1A, excavation } \\
\text { profile: "npcs" \#14 }\end{array}$ & $\mathrm{Ch}$ & $\begin{array}{l}\text { KBP } \\
4018\end{array}$ & $\begin{array}{l}\text { OS- } \\
79599\end{array}$ & $835 \pm 30$ & $793-687$ & $\mathrm{E}$ \\
\hline 7 & $\begin{array}{l}\text { B-South } \\
\text { Center }\end{array}$ & Rasshua & Rasshua 1 & Test Pit 1B, Level 4 & $\mathrm{Ch}$ & $\begin{array}{l}\text { KBP } \\
4285\end{array}$ & $\begin{array}{l}\text { OS- } \\
79860\end{array}$ & $830 \pm 25$ & $786-691$ & $E$ \\
\hline 7 & $\begin{array}{l}\text { B-South } \\
\text { Center }\end{array}$ & Rasshua & Rasshua 1 & Test Pit 1B, Level 3G & $\mathrm{Ch}$ & $\begin{array}{l}\text { KBP } \\
3911\end{array}$ & $\begin{array}{l}\text { OS- } \\
79728\end{array}$ & $315 \pm 30$ & $466-302$ & $\mathrm{E}$ \\
\hline 7 & $\begin{array}{l}\text { B-South } \\
\text { Center }\end{array}$ & Rasshua & Rasshua 1 & Test Pit 1B, Level 3C & W & $\begin{array}{l}\text { KBP } \\
3721\end{array}$ & $\begin{array}{l}\text { OS- } \\
79727\end{array}$ & $245 \pm 25$ & $423-0$ & $\mathrm{E}$ \\
\hline 7 & $\begin{array}{l}\text { B-South } \\
\text { Center }\end{array}$ & Rasshua & Rasshua 1 & $\begin{array}{l}\text { Test Pit 1B, level } 3 \mathrm{H} \text {, roof } \\
\text { structure wood sample \#1 }\end{array}$ & W & $\begin{array}{l}\text { KBP } \\
3947\end{array}$ & $\begin{array}{l}\text { OS- } \\
79729 \\
\end{array}$ & $225 \pm 30$ & $310-0$ & $\mathrm{E}$ \\
\hline 7 & $\begin{array}{l}\text { B-South } \\
\text { Center }\end{array}$ & Rasshua & Rasshua 1 & Test Pit 1B, Level 3i & $\mathrm{Ch}$ & $\begin{array}{l}\text { KBP } \\
3935\end{array}$ & $\begin{array}{l}\text { OS- } \\
79731 \\
\end{array}$ & $215 \pm 25$ & $305-0$ & $\mathrm{E}$ \\
\hline 7 & $\begin{array}{l}\text { B-South } \\
\text { Center }\end{array}$ & Rasshua & Rasshua 1 & $\begin{array}{l}\text { Test Pit } 1 \mathrm{~B} \text {, level } 3 \mathrm{H} \text {, roof } \\
\text { structure wood sample \#4 }\end{array}$ & $\mathrm{W}$ & $\begin{array}{l}\text { KBP } \\
3943\end{array}$ & $\begin{array}{l}\text { OS- } \\
79730\end{array}$ & $205 \pm 35$ & $309-0$ & $\mathrm{E}$ \\
\hline 7 & $\begin{array}{l}\text { B-South } \\
\text { Center }\end{array}$ & Rasshua & Rasshua 1 & $\begin{array}{l}\text { Test Pit 1B, excavation } \\
\text { profile sample }\end{array}$ & W & $\begin{array}{l}\text { KBP } \\
4137\end{array}$ & $\begin{array}{l}\text { OS- } \\
79664\end{array}$ & $170 \pm 30$ & $291-0$ & $E$ \\
\hline 7 & $\begin{array}{l}\text { B-South } \\
\text { Center }\end{array}$ & Rasshua & Rasshua 1 & $\begin{array}{l}\text { Erosion face, Section 1B, } \\
\text { "Ainu" level }\end{array}$ & $\mathrm{Ch}$ & $\begin{array}{l}\text { KBP } \\
1904\end{array}$ & $\begin{array}{l}\text { OS- } \\
67130\end{array}$ & $30 \pm 30$ & $255-31$ & $\mathrm{E}$ \\
\hline 7 & $\begin{array}{l}\text { B-South } \\
\text { Center }\end{array}$ & Rasshua & Rasshua 2 & $\begin{array}{l}\text { Probe Survey, Probe } 2 \text { (GPS } \\
\text { 134): below cinders }\end{array}$ & $\mathrm{Ch}$ & $\begin{array}{l}\text { KBP } \\
2128\end{array}$ & $\begin{array}{l}\text { OS- } \\
67134\end{array}$ & $1720 \pm 30$ & $\begin{array}{l}1703- \\
1560 \\
\end{array}$ & $\mathrm{C}$ \\
\hline 7 & $\begin{array}{l}\text { B-South } \\
\text { Center }\end{array}$ & Rasshua & Rasshua 2 & $\begin{array}{l}\text { Probe Survey, Probe } 3 \text { (GPS } \\
\text { 135): below first (top) }\end{array}$ & $\mathrm{Ch}$ & $\begin{array}{l}\text { KBP } \\
2130\end{array}$ & $\begin{array}{l}\text { OS- } \\
67136\end{array}$ & $1190 \pm 35$ & $1235-989$ & $E$ \\
\hline
\end{tabular}




\begin{tabular}{|c|c|c|c|c|c|c|c|c|c|c|}
\hline & & & & tephra & & & & & & \\
\hline 7 & $\begin{array}{l}\text { B-South } \\
\text { Center }\end{array}$ & Rasshua & Rasshua 2 & $\begin{array}{l}\text { Probe Survey, Probe } 3 \text { (GPS } \\
\text { 135): above first (top) } \\
\text { tephra }\end{array}$ & $\mathrm{Ch}$ & $\begin{array}{l}\text { KBP } \\
2129\end{array}$ & $\begin{array}{l}\text { OS- } \\
67135\end{array}$ & $1100 \pm 35$ & $1168-931$ & $E$ \\
\hline 7 & $\begin{array}{l}\text { B-South } \\
\text { Center }\end{array}$ & Rasshua & Rasshua 2 & $\begin{array}{l}\text { Probe Survey, Probe } 1 \text { (GPS } \\
\text { 134) } 10-15 \text { cmbs: above } \\
\text { cinders }\end{array}$ & $\mathrm{Ch}$ & $\begin{array}{l}\text { KBP } \\
2127\end{array}$ & $\begin{array}{l}\text { OS- } \\
67133\end{array}$ & $130 \pm 25$ & $273-10$ & $E$ \\
\hline 8 & $\begin{array}{l}\text { B-South } \\
\text { Center }\end{array}$ & Matua & $\begin{array}{l}\text { Ainu Bay } 1 \\
\text { and } 2\end{array}$ & $\begin{array}{l}\text { Level } 14 \text { of Y. Ishizuka's } \\
\text { geological column }\end{array}$ & $\mathrm{Ch}$ & $\begin{array}{l}\text { IKIP } \\
0113\end{array}$ & $\begin{array}{l}\text { AA- } \\
40943\end{array}$ & $2345 \pm 37$ & $\begin{array}{l}2651- \\
2211\end{array}$ & $A$ \\
\hline 8 & $\begin{array}{l}\text { B-South } \\
\text { Center }\end{array}$ & Matua & $\begin{array}{l}\text { Ainu Bay } 1 \\
\text { and } 2\end{array}$ & $\begin{array}{l}\text { Erosion face: Marsh } \\
\text { Erosional Scarp, sample 5, } \\
1-3 \mathrm{~cm} \text { below yellow tephra }\end{array}$ & $\mathrm{Ch}$ & $\begin{array}{l}\text { KBP } \\
2106\end{array}$ & $\begin{array}{l}\text { OS- } \\
67626\end{array}$ & $1970 \pm 40$ & $\begin{array}{l}1999- \\
1825\end{array}$ & $\mathrm{C}$ \\
\hline 8 & $\begin{array}{l}\text { B-South } \\
\text { Center }\end{array}$ & Matua & $\begin{array}{l}\text { Ainu Bay } 1 \\
\text { and } 2\end{array}$ & Test Pit 2, cultural level & $\mathrm{Ch}$ & $\begin{array}{l}\text { IKIP } \\
0129\end{array}$ & $\begin{array}{l}\text { AA- } \\
40942\end{array}$ & $1604 \pm 36$ & $\begin{array}{l}1565- \\
1405\end{array}$ & A \\
\hline 8 & $\begin{array}{l}\text { B-South } \\
\text { Center }\end{array}$ & Matua & $\begin{array}{l}\text { Ainu Bay } 1 \\
\text { and } 2\end{array}$ & $\begin{array}{l}\text { Test Pit 5, road cut, upper } \\
\text { level }\end{array}$ & $\mathrm{Ch}$ & $\begin{array}{l}\text { KBP } \\
2089\end{array}$ & $\begin{array}{l}\text { OS- } \\
67589\end{array}$ & $815 \pm 30$ & $782-684$ & $E$ \\
\hline 8 & $\begin{array}{l}\text { B-South } \\
\text { Center }\end{array}$ & Matua & $\begin{array}{l}\text { Ainu Bay } 1 \\
\text { and } 2\end{array}$ & $\begin{array}{l}\text { Geo Survey: (Maclnness } \\
\text { GPS 91), cultural deposit }\end{array}$ & $\mathrm{Ch}$ & $\begin{array}{l}\text { KBP } \\
2617\end{array}$ & $\begin{array}{l}\text { OS- } \\
67621\end{array}$ & $815 \pm 25$ & $781-685$ & $E$ \\
\hline 8 & $\begin{array}{l}\text { B-South } \\
\text { Center }\end{array}$ & Matua & $\begin{array}{l}\text { Ainu Bay } 1 \\
\text { and } 2\end{array}$ & $\begin{array}{l}\text { Erosion face; Marsh } \\
\text { Erosional Scarp, sample 4, } \\
1-2 \mathrm{~cm} \text { below brown tephra }\end{array}$ & $\mathrm{Ch}$ & $\begin{array}{l}\text { KBP } \\
2105\end{array}$ & $\begin{array}{l}\text { OS- } \\
67590\end{array}$ & $295 \pm 25$ & $455-296$ & $E$ \\
\hline 8 & $\begin{array}{l}\text { B-South } \\
\text { Center }\end{array}$ & Matua & Ikeda Bay & Cliff profile, $45-46 \mathrm{cmbs}$ & $\mathrm{Ch}$ & $\begin{array}{l}\text { IKIP } \\
0141\end{array}$ & $\begin{array}{l}\text { AA- } \\
42201\end{array}$ & $66 \pm 38$ & $266-22$ & A \\
\hline 9 & $\begin{array}{l}\text { C-North } \\
\text { Central }\end{array}$ & Shiashkotan & Bashmak 1 & Test Pit 1, $15 \mathrm{cmbs}$ & $\mathrm{Ch}$ & $\begin{array}{l}\text { KBP } \\
3153\end{array}$ & $\begin{array}{l}\text { OS- } \\
95632\end{array}$ & $265 \pm 35$ & $458-0$ & $\mathrm{E}$ \\
\hline 9 & $\begin{array}{l}\text { C-North } \\
\text { Central }\end{array}$ & Shiashkotan & Bashmak 2 & $\begin{array}{l}\text { Probe Survey, house pit } 2 \text {, } \\
55 \mathrm{cmbs}\end{array}$ & $\mathrm{Ch}$ & $\begin{array}{l}\text { KBP } \\
3166\end{array}$ & $\begin{array}{l}\text { OS- } \\
80021\end{array}$ & $370 \pm 30$ & $504-317$ & C \\
\hline 9 & $\begin{array}{l}\text { C-North } \\
\text { Central }\end{array}$ & Shiashkotan & Bashmak 2 & $\begin{array}{l}\text { Test Pit 1, Level 3, from } \\
\text { yellow sand (tephra?) lens } \\
\text { on north wall profile }\end{array}$ & $\mathrm{Ch}$ & $\begin{array}{l}\text { KBP } \\
3164\end{array}$ & $\begin{array}{l}\text { OS- } \\
80023\end{array}$ & $340 \pm 25$ & $478-313$ & $E$ \\
\hline 9 & $\begin{array}{l}\text { C-North } \\
\text { Central }\end{array}$ & Shiashkotan & Bashmak 2 & $\begin{array}{l}\text { Test Pit 1, Level 3, } 61 \mathrm{cmbd} \text { : } \\
\text { (next to artifact \#3165) }\end{array}$ & $\mathrm{Ch}$ & $\begin{array}{l}\text { KBP } \\
3162 \mathrm{a}\end{array}$ & $\begin{array}{l}\text { OS- } \\
80022\end{array}$ & $280 \pm 25$ & $435-158$ & $E$ \\
\hline 9 & $\begin{array}{l}\text { C-North } \\
\text { Central }\end{array}$ & Shiashkotan & Bashmak 3 & Test Pit 1, $74 \mathrm{cmbs}$ & $\mathrm{Ch}$ & $\begin{array}{l}\text { KBP } \\
3173\end{array}$ & $\begin{array}{l}\text { OS- } \\
80026\end{array}$ & $905 \pm 25$ & $913-746$ & C \\
\hline
\end{tabular}




\begin{tabular}{|c|c|c|c|c|c|c|c|c|c|c|}
\hline 9 & $\begin{array}{l}\text { C-North } \\
\text { Central }\end{array}$ & Shiashkotan & Bashmak 3 & Test Pit 1, $57 \mathrm{cmbs}$ & $\mathrm{Ch}$ & $\begin{array}{l}\text { KBP } \\
3169\end{array}$ & $\begin{array}{l}\text { OS- } \\
80025\end{array}$ & $805 \pm 35$ & $783-677$ & $E$ \\
\hline 9 & $\begin{array}{l}\text { C-North } \\
\text { Central }\end{array}$ & Shiashkotan & Bashmak 3 & $\begin{array}{l}\text { Probe Survey, house pit } 6 \\
\text { (GPS 475), } 40 \mathrm{cmbs}\end{array}$ & $\mathrm{Ch}$ & $\begin{array}{l}\text { KBP } \\
3170\end{array}$ & $\begin{array}{l}\text { OS- } \\
80024\end{array}$ & $260 \pm 25$ & $429-151$ & $E$ \\
\hline 9 & $\begin{array}{l}\text { C-North } \\
\text { Central }\end{array}$ & Shiashkotan & Drobnyye 1 & $\begin{array}{l}\text { Probe Survey, Probe } 36, \\
\text { house pit } \_ \text {GPS } 446\end{array}$ & $\mathrm{Ch}$ & $\begin{array}{l}\text { KBP } \\
1673\end{array}$ & $\begin{array}{l}\text { OS- } \\
67483\end{array}$ & $2990 \pm 30$ & $\begin{array}{l}3323- \\
3067\end{array}$ & $\mathrm{C}$ \\
\hline 9 & $\begin{array}{l}\text { C-North } \\
\text { Central }\end{array}$ & Shiashkotan & Drobnyye 1 & $\begin{array}{l}\text { Probe Survey, Probe } 30, \\
\text { house pit } 260, \text { pit next to } \\
\text { house, GPS } 439\end{array}$ & $\mathrm{Ch}$ & $\begin{array}{l}\text { KBP } \\
1666\end{array}$ & $\begin{array}{l}\text { OS- } \\
67479\end{array}$ & $2960 \pm 40$ & $\begin{array}{l}3235- \\
2980\end{array}$ & $E$ \\
\hline 9 & $\begin{array}{l}\text { C-North } \\
\text { Central }\end{array}$ & Shiashkotan & Drobnyye 1 & $\begin{array}{l}\text { Unit } 4 \text {, Level } 4,37 \mathrm{cmbd} \text {, } \\
\text { within compact sand }\end{array}$ & $\mathrm{Ch}$ & $\begin{array}{l}\text { KBP } \\
1715 \\
\end{array}$ & $\begin{array}{l}\text { OS- } \\
67469 \\
\end{array}$ & $2920 \pm 30$ & $\begin{array}{l}3160- \\
2969\end{array}$ & $E$ \\
\hline 9 & $\begin{array}{l}\text { C-North } \\
\text { Central }\end{array}$ & Shiashkotan & Drobnyye 1 & $\begin{array}{l}\text { Probe Survey, Probe } 29, \\
\text { house pit } 260, \text { GPS } 438\end{array}$ & $\mathrm{Ch}$ & $\begin{array}{l}\text { KBP } \\
1665 \\
\end{array}$ & $\begin{array}{l}\text { OS- } \\
67443 \\
\end{array}$ & $2900 \pm 30$ & $\begin{array}{l}3156- \\
2953\end{array}$ & $E$ \\
\hline 9 & $\begin{array}{l}\text { C-North } \\
\text { Central }\end{array}$ & Shiashkotan & Drobnyye 1 & $\begin{array}{l}\text { Probe Survey, Probe } 43, \\
\text { house pit } 278, \text { GPS } 453\end{array}$ & $\mathrm{Ch}$ & $\begin{array}{l}\text { KBP } \\
1680\end{array}$ & $\begin{array}{l}\text { OS- } \\
67446 \\
\end{array}$ & $2630 \pm 25$ & $\begin{array}{l}2779- \\
2738\end{array}$ & $E$ \\
\hline 9 & $\begin{array}{l}\text { C-North } \\
\text { Central }\end{array}$ & Shiashkotan & Drobnyye 1 & $\begin{array}{l}\text { Unit 1, Level 4, } 119 \mathrm{~cm} \\
\text { charcoal, pit bottom }\end{array}$ & $\mathrm{Ch}$ & $\begin{array}{l}\text { KBP } \\
1798\end{array}$ & $\begin{array}{l}\text { OS- } \\
79900\end{array}$ & $2440 \pm 25$ & $\begin{array}{l}2699- \\
2357\end{array}$ & $E$ \\
\hline 9 & $\begin{array}{l}\text { C-North } \\
\text { Central }\end{array}$ & Shiashkotan & Drobnyye 1 & Test Pit 1, Level 6 & $\mathrm{Ch}$ & $\begin{array}{l}\text { KBP } \\
0770\end{array}$ & $\begin{array}{l}\text { OS- } \\
59195\end{array}$ & $2130 \pm 35$ & $\begin{array}{l}2301- \\
1999\end{array}$ & $\mathrm{E}$ \\
\hline 9 & $\begin{array}{l}\text { C-North } \\
\text { Central }\end{array}$ & Shiashkotan & Drobnyye 1 & Unit $2 ; 82-83 \mathrm{cmbd}$ & $\mathrm{Ch}$ & $\begin{array}{l}\text { KBP } \\
2672\end{array}$ & $\begin{array}{l}\text { OS- } \\
67419\end{array}$ & $2080 \pm 30$ & $\begin{array}{l}2140- \\
1952\end{array}$ & $\mathrm{E}$ \\
\hline 9 & $\begin{array}{l}\text { C-North } \\
\text { Central }\end{array}$ & Shiashkotan & Drobnyye 1 & Unit 2; 57-63 cmbd & $\mathrm{Ch}$ & $\begin{array}{l}\text { KBP } \\
2671\end{array}$ & $\begin{array}{l}\text { OS- } \\
67418\end{array}$ & $1960 \pm 25$ & $\begin{array}{l}1987- \\
1835\end{array}$ & $\mathrm{E}$ \\
\hline 9 & $\begin{array}{l}\text { C-North } \\
\text { Central }\end{array}$ & Shiashkotan & Drobnyye 1 & $\begin{array}{l}\text { Probe Survey, Probe } 7, \\
\text { house pit } 231, \text { GPS } 417\end{array}$ & $\mathrm{Ch}$ & $\begin{array}{l}\text { KBP } \\
1651\end{array}$ & $\begin{array}{l}\text { OS- } \\
67415\end{array}$ & $1920 \pm 25$ & $\begin{array}{l}1926- \\
1820\end{array}$ & $\mathrm{E}$ \\
\hline 9 & $\begin{array}{l}\text { C-North } \\
\text { Central }\end{array}$ & Shiashkotan & Drobnyye 1 & $\begin{array}{l}\text { Probe Survey, Probe } 3, \\
\text { house pit } 0235\end{array}$ & $\mathrm{Ch}$ & $\begin{array}{l}\text { KBP } \\
1647\end{array}$ & $\begin{array}{l}\text { OS- } \\
67414\end{array}$ & $1890 \pm 30$ & $\begin{array}{l}1895- \\
1733\end{array}$ & $\mathrm{E}$ \\
\hline 9 & $\begin{array}{l}\text { C-North } \\
\text { Central }\end{array}$ & Shiashkotan & Drobnyye 1 & $\begin{array}{l}\text { Probe Survey, Probe } 31 \\
\text { (GPS 440), house pit } 264\end{array}$ & $\mathrm{Ch}$ & $\begin{array}{l}\text { KBP } \\
1667\end{array}$ & $\begin{array}{l}\text { OS- } \\
67480\end{array}$ & $1880 \pm 30$ & $\begin{array}{l}1885- \\
1728\end{array}$ & $E$ \\
\hline 9 & $\begin{array}{l}\text { C-North } \\
\text { Central }\end{array}$ & Shiashkotan & Drobnyye 1 & $\begin{array}{l}\text { Probe Survey, Probe } 40 \\
\text { (GPS 450), house pit }\end{array}$ & $\mathrm{Ch}$ & $\begin{array}{l}\text { KBP } \\
1677\end{array}$ & $\begin{array}{l}\text { OS- } \\
67487\end{array}$ & $1800 \pm 25$ & $\begin{array}{l}1818- \\
1628\end{array}$ & $\mathrm{E}$ \\
\hline 9 & $\begin{array}{l}\text { C-North } \\
\text { Central }\end{array}$ & Shiashkotan & Drobnyye 1 & $\begin{array}{l}\text { Probe Survey, Probe } 12 \\
\text { (GPS 422), house pit } 246\end{array}$ & $\mathrm{Ch}$ & $\begin{array}{l}\text { KBP } \\
1655\end{array}$ & $\begin{array}{l}\text { OS- } \\
67423\end{array}$ & $1790 \pm 30$ & $\begin{array}{l}1817- \\
1620\end{array}$ & $\mathrm{E}$ \\
\hline 9 & C-North & Shiashkotan & Drobnyye 1 & Unit 3, Level 3, top $5 \mathrm{~cm}$ of & $\mathrm{Ch}$ & KBP & OS- & $1720 \pm 35$ & $1709-$ & $E$ \\
\hline
\end{tabular}




\begin{tabular}{|c|c|c|c|c|c|c|c|c|c|c|}
\hline & Central & & & level & & 1602 & 67304 & & 1554 & \\
\hline 9 & $\begin{array}{l}\text { C-North } \\
\text { Central }\end{array}$ & Shiashkotan & Drobnyye 1 & $\begin{array}{l}\text { Probe Survey, Probe } 27 \\
\text { (GPS 436), house pit } 257\end{array}$ & $\mathrm{Ch}$ & $\begin{array}{l}\text { KBP } \\
1662\end{array}$ & $\begin{array}{l}\text { OS- } \\
67441\end{array}$ & $1700 \pm 30$ & $\begin{array}{l}1697- \\
1544\end{array}$ & $E$ \\
\hline 9 & \begin{tabular}{|l|} 
C-North \\
Central \\
\end{tabular} & Shiashkotan & Drobnyye 1 & Unit 1, Level 4, $108 \mathrm{cmbl}$ & $\mathrm{Ch}$ & $\begin{array}{l}\text { KBP } \\
1695 \\
\end{array}$ & $\begin{array}{l}\text { OS- } \\
79899 \\
\end{array}$ & $1660 \pm 25$ & $\begin{array}{l}1685- \\
1523\end{array}$ & $E$ \\
\hline 9 & \begin{tabular}{|l|} 
C-North \\
Central \\
\end{tabular} & Shiashkotan & Drobnyye 1 & $\begin{array}{l}\text { Probe Survey, Probe } 18 \\
\text { (GPS 428), house pit } 248\end{array}$ & $\mathrm{Ch}$ & $\begin{array}{l}\text { KBP } \\
1658 \\
\end{array}$ & $\begin{array}{l}\text { OS- } \\
67424 \\
\end{array}$ & $1620 \pm 30$ & $\begin{array}{l}1569- \\
1412 \\
\end{array}$ & $E$ \\
\hline 9 & $\begin{array}{l}\text { C-North } \\
\text { Central }\end{array}$ & Shiashkotan & Drobnyye 1 & $\begin{array}{l}\text { Probe Survey, Probe } 20 \\
\text { (GPS 430), house pit } 238\end{array}$ & $\mathrm{Ch}$ & $\begin{array}{l}\text { KBP } \\
1659\end{array}$ & $\begin{array}{l}\text { OS- } \\
67425\end{array}$ & $1610 \pm 30$ & $\begin{array}{l}1559- \\
1412\end{array}$ & $E$ \\
\hline 9 & $\begin{array}{l}\text { C-North } \\
\text { Central } \\
\end{array}$ & Shiashkotan & Drobnyye 1 & $\begin{array}{l}\text { Probe Survey, Probe } 23 \\
\text { (GPS 433), house pit } 253\end{array}$ & $\mathrm{Ch}$ & $\begin{array}{l}\text { KBP } \\
1661\end{array}$ & $\begin{array}{l}\text { OS- } \\
67440\end{array}$ & $1570 \pm 35$ & $\begin{array}{l}1541- \\
1386\end{array}$ & $E$ \\
\hline 9 & $\begin{array}{l}\text { C-North } \\
\text { Central } \\
\end{array}$ & Shiashkotan & Drobnyye 1 & Unit 1, Level 3, $93 \mathrm{cmbd}$ & $\mathrm{Ch}$ & $\begin{array}{l}\text { KBP } \\
1610\end{array}$ & $\begin{array}{l}\text { OS- } \\
79898\end{array}$ & $1550 \pm 25$ & $\begin{array}{l}1525- \\
1384\end{array}$ & $E$ \\
\hline 9 & $\begin{array}{l}\text { C-North } \\
\text { Central } \\
\end{array}$ & Shiashkotan & Drobnyye 1 & Test Pit 1, Level 5 & $\mathrm{Ch}$ & $\begin{array}{l}\text { KBP } \\
0765\end{array}$ & $\begin{array}{l}\text { OS- } \\
59107\end{array}$ & $1470 \pm 35$ & $\begin{array}{l}1413- \\
1299\end{array}$ & $\mathrm{D}$ \\
\hline 9 & $\begin{array}{l}\text { C-North } \\
\text { Central }\end{array}$ & Shiashkotan & Drobnyye 1 & Test Pit 1, Level 4 & $\mathrm{Ch}$ & $\begin{array}{l}\text { KBP } \\
0758\end{array}$ & $\begin{array}{l}\text { OS- } \\
59190\end{array}$ & $1460 \pm 35$ & $\begin{array}{l}1405- \\
1300\end{array}$ & $E$ \\
\hline 9 & $\begin{array}{l}\text { C-North } \\
\text { Central }\end{array}$ & Shiashkotan & Drobnyye 1 & $\begin{array}{l}\text { Unit 1, Level 2, } 55 \mathrm{cmbd} \text {, } \\
\text { charcoal sample \#2 }\end{array}$ & $\mathrm{Ch}$ & $\begin{array}{l}\text { KBP } \\
1592\end{array}$ & $\begin{array}{l}\text { OS- } \\
79897\end{array}$ & $1290 \pm 30$ & $\begin{array}{l}1286- \\
1180\end{array}$ & $E$ \\
\hline 9 & \begin{tabular}{|l|} 
C-North \\
Central
\end{tabular} & Shiashkotan & Drobnyye 1 & $\begin{array}{l}\text { Probe Survey, Probe } 4 \text { (GPS } \\
\# 415 \text { ), house pit } 234\end{array}$ & $\mathrm{Ch}$ & $\begin{array}{l}\text { KBP } \\
1648\end{array}$ & $\begin{array}{l}\text { OS- } \\
67421\end{array}$ & $1250 \pm 30$ & $\begin{array}{l}1274- \\
1080\end{array}$ & $E$ \\
\hline 9 & $\begin{array}{l}\text { C-North } \\
\text { Central } \\
\end{array}$ & Shiashkotan & Drobnyye 1 & $\begin{array}{l}\text { Probe Survey, Probe } 27 \\
\text { (GPS 435), house pit } 256\end{array}$ & $\mathrm{Ch}$ & $\begin{array}{l}\text { KBP } \\
1663\end{array}$ & $\begin{array}{l}\text { OS- } \\
67442\end{array}$ & $1130 \pm 35$ & $1174-961$ & $E$ \\
\hline 9 & $\begin{array}{l}\text { C-North } \\
\text { Central }\end{array}$ & Shiashkotan & Drobnyye 1 & Test Pit 1, Level 2 & $\mathrm{Ch}$ & $\begin{array}{l}\text { KBP } \\
0715\end{array}$ & $\begin{array}{l}\text { OS- } \\
59036\end{array}$ & $1110 \pm 25$ & $1064-960$ & $\mathrm{D}$ \\
\hline 9 & $\begin{array}{l}\text { C-North } \\
\text { Central } \\
\end{array}$ & Shiashkotan & Drobnyye 1 & Unit 3, Level 4, 62-63 cmbl & $\mathrm{Ch}$ & $\begin{array}{l}\text { KBP } \\
1642\end{array}$ & $\begin{array}{l}\text { OS- } \\
67413\end{array}$ & $1110 \pm 25$ & $1064-960$ & $\mathrm{D}$ \\
\hline 9 & $\begin{array}{l}\text { C-North } \\
\text { Central }\end{array}$ & Shiashkotan & Drobnyye 1 & $\begin{array}{l}\text { Test Pit 2, Level 2, base of } \\
\text { level near Epi-Jomon } \\
\text { ceramic }\end{array}$ & $\mathrm{Ch}$ & $\begin{array}{l}\text { KBP } \\
0723\end{array}$ & $\begin{array}{l}\text { OS- } \\
58974\end{array}$ & $960 \pm 25$ & $930-796$ & D \\
\hline 9 & \begin{tabular}{|l|} 
C-North \\
Central \\
\end{tabular} & Shiashkotan & Drobnyye 1 & $\begin{array}{l}\text { Probe Survey, Probe } 54 \\
\text { (GPS 466), house pit } 286\end{array}$ & $\mathrm{Ch}$ & $\begin{array}{l}\text { KBP } \\
1684 \\
\end{array}$ & $\begin{array}{l}\text { OS- } \\
67488 \\
\end{array}$ & $950 \pm 30$ & $926-795$ & $E$ \\
\hline 9 & \begin{tabular}{|l|} 
C-North \\
Central \\
\end{tabular} & Shiashkotan & Drobnyye 1 & $\begin{array}{l}\text { Probe Survey, Probe } 5 \text { (GPS } \\
416 \text { ), house pit } 0233\end{array}$ & $\mathrm{Ch}$ & $\begin{array}{l}\text { KBP } \\
1649 \\
\end{array}$ & $\begin{array}{l}\text { OS- } \\
67422 \\
\end{array}$ & $920 \pm 25$ & $920-783$ & $E$ \\
\hline
\end{tabular}




\begin{tabular}{|c|c|c|c|c|c|c|c|c|c|c|}
\hline 9 & $\begin{array}{l}\text { C-North } \\
\text { Central }\end{array}$ & Shiashkotan & Drobnyye 1 & Unit 3, Level 3 & $\mathrm{Ch}$ & $\begin{array}{l}\text { KBP } \\
1603\end{array}$ & $\begin{array}{l}\text { OS- } \\
67406 \\
\end{array}$ & $870 \pm 30$ & $905-701$ & $E$ \\
\hline 9 & $\begin{array}{l}\text { C-North } \\
\text { Central }\end{array}$ & Shiashkotan & Drobnyye 1 & $\begin{array}{l}\text { Probe Survey, Probe } 42 \\
\text { (GPS 452), house pit } 280\end{array}$ & $\mathrm{Ch}$ & $\begin{array}{l}\text { KBP } \\
1679\end{array}$ & $\begin{array}{l}\text { OS- } \\
67445\end{array}$ & $860 \pm 25$ & $898-699$ & $E$ \\
\hline 9 & $\begin{array}{l}\text { C-North } \\
\text { Central }\end{array}$ & Shiashkotan & Drobnyye 1 & $\begin{array}{l}\text { Probe Survey, Probe } 6 \text { (GPS } \\
416 \text { ), house pit } 232\end{array}$ & $\mathrm{Ch}$ & $\begin{array}{l}\text { KBP } \\
1650\end{array}$ & $\begin{array}{l}\text { OS- } \\
67584\end{array}$ & $830 \pm 30$ & $790-687$ & $\mathrm{E}$ \\
\hline 9 & $\begin{array}{l}\text { C-North } \\
\text { Central }\end{array}$ & Shiashkotan & Drobnyye 1 & $\begin{array}{l}\text { Probe Survey, Probe } 39 \\
\text { (GPS 449), house pit } 292\end{array}$ & $\mathrm{Ch}$ & $\begin{array}{l}\text { KBP } \\
1676\end{array}$ & $\begin{array}{l}\text { OS- } \\
67585\end{array}$ & $825 \pm 30$ & $787-687$ & $\mathrm{E}$ \\
\hline 9 & $\begin{array}{l}\text { C-North } \\
\text { Central }\end{array}$ & Shiashkotan & Drobnyye 1 & $\begin{array}{l}\text { Probe Survey, Probe } 38 \\
\text { (GPS 448), house pit } 296\end{array}$ & $\mathrm{Ch}$ & $\begin{array}{l}\text { KBP } \\
1675\end{array}$ & $\begin{array}{l}\text { OS- } \\
67444\end{array}$ & $760 \pm 30$ & $731-666$ & $\mathrm{E}$ \\
\hline 9 & $\begin{array}{l}\text { C-North } \\
\text { Central }\end{array}$ & Shiashkotan & Drobnyye 1 & $\begin{array}{l}\text { Test Pit 1, Level 3, above } \\
\text { Tephra }\end{array}$ & $\mathrm{Ch}$ & $\begin{array}{l}\text { KBP } \\
0750\end{array}$ & $\begin{array}{l}\text { OS- } \\
59106\end{array}$ & $750 \pm 30$ & $728-664$ & $\mathrm{D}$ \\
\hline 9 & $\begin{array}{l}\text { C-North } \\
\text { Central }\end{array}$ & Shiashkotan & Drobnyye 1 & Unit 4, Level 3, top of level & $\mathrm{Ch}$ & $\begin{array}{l}\text { KBP } \\
1634\end{array}$ & $\begin{array}{l}\text { OS- } \\
67407\end{array}$ & $310 \pm 25$ & $459-303$ & $\mathrm{E}$ \\
\hline 9 & $\begin{array}{l}\text { C-North } \\
\text { Central }\end{array}$ & Shiashkotan & Drobnyye 1 & $\begin{array}{l}\text { Probe Survey, Probe } 32 \\
\text { (GPS 463), house pit }\end{array}$ & $\mathrm{Ch}$ & $\begin{array}{l}\text { KBP } \\
1668\end{array}$ & $\begin{array}{l}\text { OS- } \\
67481\end{array}$ & $150 \pm 25$ & $284-0$ & $\mathrm{E}$ \\
\hline 9 & $\begin{array}{l}\text { C-North } \\
\text { Central }\end{array}$ & Shiashkotan & Drobnyye 1 & $\begin{array}{l}\text { Probe Survey, Probe } 9 \text { (GPS } \\
419 \text { ), house pit } 252\end{array}$ & $\mathrm{Ch}$ & $\begin{array}{l}\text { KBP } \\
1653\end{array}$ & $\begin{array}{l}\text { OS- } \\
67416\end{array}$ & $130 \pm 30$ & $276-9$ & $\mathrm{E}$ \\
\hline 9 & $\begin{array}{l}\text { C-North } \\
\text { Central }\end{array}$ & Shiashkotan & Drobnyye 1 & $\begin{array}{l}\text { Probe Survey, Probe } 35 \\
\text { (GPS 444), house pit } 261\end{array}$ & $\mathrm{Ch}$ & $\begin{array}{l}\text { KBP } \\
1672\end{array}$ & $\begin{array}{l}\text { OS- } \\
67482\end{array}$ & $130 \pm 25$ & $273-10$ & $\mathrm{E}$ \\
\hline 9 & $\begin{array}{l}\text { C-North } \\
\text { Central }\end{array}$ & Shiashkotan & Drobnyye 1 & $\begin{array}{l}\text { Probe Survey, Probe } 47 \\
\text { (GPS 458) }\end{array}$ & $\mathrm{Ch}$ & $\begin{array}{l}\text { KBP } \\
1682 \\
\end{array}$ & $\begin{array}{l}\text { OS- } \\
67447 \\
\end{array}$ & $130 \pm 25$ & $273-10$ & $E$ \\
\hline 9 & $\begin{array}{l}\text { C-North } \\
\text { Central }\end{array}$ & Shiashkotan & Drobnyye 1 & $\begin{array}{l}\text { Probe Survey, Probe } 37 \\
\text { (GPS 447), house pit } 295\end{array}$ & $\mathrm{Ch}$ & $\begin{array}{l}\text { KBP } \\
1674\end{array}$ & $\begin{array}{l}\text { OS- } \\
67484 \\
\end{array}$ & $120 \pm 30$ & $272-11$ & $\mathrm{E}$ \\
\hline 9 & $\begin{array}{l}\text { C-North } \\
\text { Central }\end{array}$ & Shiashkotan & Grotovyye 1 & Test Pit 2; 31-35 cmbs, bulk & $\mathrm{Ch}$ & $\begin{array}{l}\text { KBP } \\
0868\end{array}$ & $\begin{array}{l}\text { OS- } \\
95617\end{array}$ & $880 \pm 25$ & $905-730$ & $\mathrm{C}$ \\
\hline 9 & $\begin{array}{l}\text { C-North } \\
\text { Central }\end{array}$ & Shiashkotan & Grotovyye 1 & Test Pit 1, Level 2 & $\mathrm{Ch}$ & $\begin{array}{l}\text { KBP } \\
0858\end{array}$ & $\begin{array}{l}\text { OS- } \\
97899\end{array}$ & $150 \pm 20$ & $284-2$ & $\mathrm{E}$ \\
\hline 9 & $\begin{array}{l}\text { C-North } \\
\text { Central }\end{array}$ & Shiashkotan & Rebristyy 1 & $\begin{array}{l}\text { Probe Survey, house pit 96, } \\
\text { N48.80418, E154.13298 }\end{array}$ & $\mathrm{Ch}$ & $\begin{array}{l}\text { KBP } \\
2087\end{array}$ & $\begin{array}{l}\text { OS- } \\
67409\end{array}$ & $1260 \pm 35$ & $\begin{array}{l}1283- \\
1083\end{array}$ & $\mathrm{C}$ \\
\hline 9 & $\begin{array}{l}\text { C-North } \\
\text { Central }\end{array}$ & Shiashkotan & Rebristyy 1 & $\begin{array}{l}\text { Probe Survey, house pit 97, } \\
\text { N48.80418, E154.13293 }\end{array}$ & $\mathrm{Ch}$ & $\begin{array}{l}\text { KBP } \\
2088\end{array}$ & $\begin{array}{l}\text { OS- } \\
67410\end{array}$ & $680 \pm 25$ & $677-563$ & $\mathrm{E}$ \\
\hline 9 & $\begin{array}{l}\text { C-North } \\
\text { Central }\end{array}$ & Shiashkotan & Rebristyy 1 & $\begin{array}{l}\text { Probe Survey, house pit 99, } \\
\text { N48.80439, E154.13293 }\end{array}$ & $\mathrm{Ch}$ & $\begin{array}{l}\text { KBP } \\
2086\end{array}$ & $\begin{array}{l}\text { OS- } \\
67402\end{array}$ & $255 \pm 25$ & $427-0$ & $\mathrm{E}$ \\
\hline
\end{tabular}




\begin{tabular}{|c|c|c|c|c|c|c|c|c|c|c|}
\hline 9 & $\begin{array}{l}\text { C-North } \\
\text { Central }\end{array}$ & Shiashkotan & Zakatnaya & $\begin{array}{l}\text { Test Pit } 1 \text {, marine mammal } \\
\text { bone near surface }\end{array}$ & BM & $\begin{array}{l}\text { IKIP } \\
0117\end{array}$ & $\begin{array}{l}\text { AA- } \\
44273\end{array}$ & $983 \pm 34$ & $636-5135$ & $A$ \\
\hline 10 & $\begin{array}{l}\text { C-North } \\
\text { Central }\end{array}$ & Ekarma & Ekarma 11 & Test Pit 1, Level 1, $60 \mathrm{cmbs}$ & $\mathrm{Ch}$ & $\begin{array}{l}\text { KBP } \\
2060\end{array}$ & $\begin{array}{l}\text { OS- } \\
67382\end{array}$ & $1230 \pm 25$ & $\begin{array}{l}1260- \\
1069\end{array}$ & $\mathrm{C}$ \\
\hline 10 & $\begin{array}{l}\text { C-North } \\
\text { Central }\end{array}$ & Ekarma & Ekarma 11 & Test Pit 1, Level 3, SE quad & $\mathrm{Ch}$ & $\begin{array}{l}\text { KBP } \\
2964\end{array}$ & $\begin{array}{l}\text { OS- } \\
79903\end{array}$ & $1180 \pm 25$ & $\begin{array}{l}1180- \\
1006\end{array}$ & $E$ \\
\hline 10 & $\begin{array}{l}\text { C-North } \\
\text { Central }\end{array}$ & Ekarma & Ekarma 11 & $\begin{array}{l}\text { Test Pit 1, East Profile, } \\
\text { bottom Layer L; charcoal } \\
\text { sample \#15 }\end{array}$ & $\mathrm{Ch}$ & $\begin{array}{l}\text { KBP } \\
3125\end{array}$ & $\begin{array}{l}\text { OS- } \\
79910\end{array}$ & $1100 \pm 25$ & $1062-956$ & $E$ \\
\hline 10 & $\begin{array}{l}\text { C-North } \\
\text { Central }\end{array}$ & Ekarma & Ekarma 11 & $\begin{array}{l}\text { Probe Survey, house pit "7" } \\
\text { from probe }\end{array}$ & $\mathrm{Ch}$ & $\begin{array}{l}\text { KBP } \\
3143 \\
\end{array}$ & $\begin{array}{l}\text { OS- } \\
79937\end{array}$ & $1070 \pm 25$ & $1054-930$ & $E$ \\
\hline 10 & $\begin{array}{l}\text { C-North } \\
\text { Central }\end{array}$ & Ekarma & Ekarma 11 & Test Pit 1, Level 4 & $\mathrm{Ch}$ & $\begin{array}{l}\mathrm{KBP} \\
3062 \\
\end{array}$ & $\begin{array}{l}\text { OS- } \\
98013\end{array}$ & $1070 \pm 20$ & $1050-931$ & $E$ \\
\hline 10 & $\begin{array}{l}\text { C-North } \\
\text { Central }\end{array}$ & Ekarma & Ekarma 11 & $\begin{array}{l}\text { Probe Survey, house pit 4, } \\
\text { cultural layer }\end{array}$ & $\mathrm{Ch}$ & $\begin{array}{l}\text { KBP } \\
3013\end{array}$ & $\begin{array}{l}\text { OS- } \\
79933\end{array}$ & $1040 \pm 25$ & $1045-921$ & $E$ \\
\hline 10 & $\begin{array}{l}\text { C-North } \\
\text { Central }\end{array}$ & Ekarma & Ekarma 11 & $\begin{array}{l}\text { Test Pit 1, Level 4; lots of } \\
\text { charcoal fragments }\end{array}$ & $\mathrm{Ch}$ & $\begin{array}{l}\text { KBP } \\
3127\end{array}$ & $\begin{array}{l}\text { OS- } \\
98010\end{array}$ & $1010 \pm 20$ & $965-910$ & $E$ \\
\hline 10 & $\begin{array}{l}\text { C-North } \\
\text { Central }\end{array}$ & Ekarma & Ekarma 11 & $\begin{array}{l}\text { Test Pit 1, East Profile, top } \\
\text { of Layer I; charcoal sample } \\
\# 11\end{array}$ & $\mathrm{Ch}$ & $\begin{array}{l}\text { KBP } \\
3132\end{array}$ & $\begin{array}{l}\text { OS- } \\
79908\end{array}$ & $1000 \pm 25$ & $964-802$ & $E$ \\
\hline 10 & $\begin{array}{l}\text { C-North } \\
\text { Central }\end{array}$ & Ekarma & Ekarma 11 & $\begin{array}{l}\text { Test Pit 1, Level 4, SE quad, } \\
\text { below tephra }\end{array}$ & $\mathrm{Ch}$ & $\begin{array}{l}\text { KBP } \\
3054 \\
\end{array}$ & $\begin{array}{l}\text { OS- } \\
79907\end{array}$ & $955 \pm 30$ & $928-795$ & $E$ \\
\hline 10 & $\begin{array}{l}\text { C-North } \\
\text { Central }\end{array}$ & Ekarma & Ekarma 11 & $\begin{array}{l}\text { Probe Survey, house pit 13: } \\
\text { below seven tephras }\end{array}$ & $\mathrm{Ch}$ & $\begin{array}{l}\mathrm{KBP} \\
3138 \mathrm{~b} \\
\end{array}$ & $\begin{array}{l}\text { OS- } \\
79915\end{array}$ & $955 \pm 25$ & $928-796$ & $E$ \\
\hline 10 & $\begin{array}{l}\text { C-North } \\
\text { Central }\end{array}$ & Ekarma & Ekarma 11 & $\begin{array}{l}\text { Test Pit 1, Level 3E, SW } \\
\text { quad }\end{array}$ & W & $\begin{array}{l}\text { KBP } \\
3102 \\
\end{array}$ & $\begin{array}{l}\text { OS- } \\
79905\end{array}$ & $945 \pm 25$ & $924-795$ & $E$ \\
\hline 10 & $\begin{array}{l}\text { C-North } \\
\text { Central }\end{array}$ & Ekarma & Ekarma 11 & $\begin{array}{l}\text { Test Pit 1, Level 4; SW } \\
\text { corner }\end{array}$ & W & $\begin{array}{l}\text { KBP } \\
3096 \\
\end{array}$ & $\begin{array}{l}\text { OS- } \\
79906\end{array}$ & $930 \pm 25$ & $920-790$ & $E$ \\
\hline 10 & $\begin{array}{l}\text { C-North } \\
\text { Central }\end{array}$ & Ekarma & Ekarma 11 & $\begin{array}{l}\text { Test Pit 1, East Profile, } \\
\text { Layer K- below tephra: } \\
\text { charcoal sample \#14 }\end{array}$ & $\mathrm{Ch}$ & $\begin{array}{l}\text { KBP } \\
3126\end{array}$ & $\begin{array}{l}\text { OS- } \\
79909\end{array}$ & $910 \pm 25$ & $915-764$ & $E$ \\
\hline 10 & $\begin{array}{l}\text { C-North } \\
\text { Central }\end{array}$ & Ekarma & Ekarma 11 & $\begin{array}{l}\text { Probe Survey, house pit 4: } \\
\text { charcoal below tephras }\end{array}$ & $\mathrm{Ch}$ & $\begin{array}{l}\text { KBP } \\
3146 \\
\end{array}$ & $\begin{array}{l}\text { OS- } \\
79934 \\
\end{array}$ & $905 \pm 25$ & $913-746$ & $E$ \\
\hline 10 & C-North & Ekarma & Ekarma 11 & Test Pit 1, East Profile, & $\mathrm{Ch}$ & KBP & OS- & $900 \pm 25$ & $911-741$ & $E$ \\
\hline
\end{tabular}




\begin{tabular}{|c|c|c|c|c|c|c|c|c|c|c|}
\hline & Central & & & Layer F: "\#7 Charcoal?" & & 3123 & 79911 & & & \\
\hline 10 & $\begin{array}{l}\text { C-North } \\
\text { Central }\end{array}$ & Ekarma & Ekarma 11 & $\begin{array}{l}\text { Probe Survey, house pit 2; } \\
\text { lower part of cultural zone }\end{array}$ & $\mathrm{Ch}$ & $\begin{array}{l}\text { KBP } \\
3135\end{array}$ & $\begin{array}{l}\text { OS- } \\
79932\end{array}$ & $900 \pm 25$ & $911-741$ & $\mathrm{E}$ \\
\hline 10 & $\begin{array}{l}\text { C-North } \\
\text { Central }\end{array}$ & Ekarma & Ekarma 11 & $\begin{array}{l}\text { Probe Survey, house pit } 6 \\
\text { probe; lower cultural level }\end{array}$ & $\mathrm{Ch}$ & $\begin{array}{l}\text { KBP } \\
3141\end{array}$ & $\begin{array}{l}\text { OS- } \\
79936\end{array}$ & $900 \pm 25$ & $911-741$ & $\mathrm{E}$ \\
\hline 10 & $\begin{array}{l}\text { C-North } \\
\text { Central }\end{array}$ & Ekarma & Ekarma 11 & $\begin{array}{l}\text { Probe Survey, house pit "7" } \\
\text { probe }\end{array}$ & $\mathrm{Ch}$ & $\begin{array}{l}\text { KBP } \\
3144\end{array}$ & $\begin{array}{l}\text { OS- } \\
79949\end{array}$ & $845 \pm 30$ & $893-689$ & $\mathrm{E}$ \\
\hline 10 & $\begin{array}{l}\text { C-North } \\
\text { Central }\end{array}$ & Ekarma & Ekarma 11 & Test Pit 1, Level 1: $30 \mathrm{cmbs}$ & $\mathrm{Ch}$ & $\begin{array}{l}\text { KBP } \\
2058\end{array}$ & $\begin{array}{l}\text { OS- } \\
67132\end{array}$ & $835 \pm 30$ & $793-687$ & $\mathrm{E}$ \\
\hline 10 & $\begin{array}{l}\text { C-North } \\
\text { Central }\end{array}$ & Ekarma & Ekarma 11 & $\begin{array}{l}\text { Probe Survey, house pit 6; } \\
\text { top cultural level }\end{array}$ & $\mathrm{Ch}$ & $\begin{array}{l}\text { KBP } \\
3140\end{array}$ & $\begin{array}{l}\text { OS- } \\
79935\end{array}$ & $395 \pm 25$ & $510-330$ & $\mathrm{E}$ \\
\hline 10 & $\begin{array}{l}\text { C-North } \\
\text { Central }\end{array}$ & Ekarma & Ekarma 2 & $\begin{array}{l}\text { Probe Survey, house pit 15, } \\
\text { brown cultural layer }\end{array}$ & $\mathrm{Ch}$ & $\begin{array}{l}\text { KBP } \\
3069\end{array}$ & $\begin{array}{l}\text { OS- } \\
79931\end{array}$ & $2000 \pm 25$ & $\begin{array}{l}1998- \\
1891\end{array}$ & C \\
\hline 10 & $\begin{array}{l}\text { C-North } \\
\text { Central }\end{array}$ & Ekarma & Ekarma 2 & $\begin{array}{l}\text { Probe Survey, house pit 1, } \\
34 \mathrm{cmbs}\end{array}$ & $\mathrm{Ch}$ & $\begin{array}{l}\text { KBP } \\
3023\end{array}$ & $\begin{array}{l}\text { OS- } \\
79914\end{array}$ & $1930 \pm 25$ & $\begin{array}{l}1929- \\
1822\end{array}$ & $\mathrm{E}$ \\
\hline 10 & $\begin{array}{l}\text { C-North } \\
\text { Central }\end{array}$ & Ekarma & Ekarma 2 & $\begin{array}{l}\text { Probe Survey, house pit 13, } \\
\text { cultural layer }\end{array}$ & $\mathrm{Ch}$ & $\begin{array}{l}\text { KBP } \\
3068\end{array}$ & $\begin{array}{l}\text { OS- } \\
79916\end{array}$ & $1900 \pm 30$ & $\begin{array}{l}1922- \\
1737\end{array}$ & $\mathrm{E}$ \\
\hline 10 & $\begin{array}{l}\text { C-North } \\
\text { Central }\end{array}$ & Ekarma & Ekarma 2 & Test Pit 1, Level 3 & $\mathrm{Ch}$ & $\begin{array}{l}\text { KBP } \\
3079\end{array}$ & $\begin{array}{l}\text { OS- } \\
79904\end{array}$ & $940 \pm 30$ & $925-791$ & $\mathrm{E}$ \\
\hline 10 & $\begin{array}{l}\text { C-North } \\
\text { Central }\end{array}$ & Ekarma & Ekarma 2 & Test Pit 1, Level 1 & $\mathrm{Ch}$ & $\begin{array}{l}\text { KBP } \\
3071\end{array}$ & $\begin{array}{l}\text { OS- } \\
79901\end{array}$ & $925 \pm 30$ & $925-768$ & $\mathrm{E}$ \\
\hline 10 & $\begin{array}{l}\text { C-North } \\
\text { Central }\end{array}$ & Ekarma & Ekarma 2 & $\begin{array}{l}\text { Test Pit 1, Level 2, below } \\
\text { grey tephra }\end{array}$ & $\mathrm{Ch}$ & $\begin{array}{l}\text { KBP } \\
3073\end{array}$ & $\begin{array}{l}\text { OS- } \\
79902\end{array}$ & $845 \pm 25$ & $793-694$ & $\mathrm{E}$ \\
\hline 10 & $\begin{array}{l}\text { C-North } \\
\text { Central }\end{array}$ & Ekarma & Ekarma 2 & $\begin{array}{l}\text { Probe Survey, house pit 9, } \\
20-28 \mathrm{cmbs}\end{array}$ & $\mathrm{Ch}$ & $\begin{array}{l}\text { KBP } \\
3028\end{array}$ & $\begin{array}{l}\text { OS- } \\
80014\end{array}$ & $695 \pm 30$ & $687-563$ & $\mathrm{E}$ \\
\hline 11 & $\begin{array}{l}\text { C-North } \\
\text { Central }\end{array}$ & Chirinkotan & Chirinkotan 1 & $\begin{array}{l}\text { Erosion face, Profile 1, } 180 \\
\text { cmbs }\end{array}$ & $\mathrm{Ch}$ & $\begin{array}{l}\text { KBP } \\
2077\end{array}$ & $\begin{array}{l}\text { OS- } \\
67124\end{array}$ & $1620 \pm 30$ & $\begin{array}{l}1569- \\
1412\end{array}$ & $\mathrm{E}$ \\
\hline 11 & $\begin{array}{l}\text { C-North } \\
\text { Central }\end{array}$ & Chirinkotan & Chirinkotan 1 & $\begin{array}{l}\text { Erosion face, Profile 1, } 161 \\
\text { cmbs }\end{array}$ & $\mathrm{Ch}$ & $\begin{array}{l}\text { KBP } \\
2076\end{array}$ & $\begin{array}{l}\text { OS- } \\
67090\end{array}$ & $1610 \pm 25$ & $\begin{array}{l}1555- \\
1414 \\
\end{array}$ & $E$ \\
\hline 11 & $\begin{array}{l}\text { C-North } \\
\text { Central }\end{array}$ & Chirinkotan & Chirinkotan 1 & $\begin{array}{l}\text { Erosion face, Profile 1, } 110 \\
\text { cmbs }\end{array}$ & $\mathrm{Ch}$ & $\begin{array}{l}\text { KBP } \\
2075\end{array}$ & $\begin{array}{l}\text { OS- } \\
67089 \\
\end{array}$ & $1130 \pm 25$ & $1173-963$ & $\mathrm{E}$ \\
\hline 11 & $\begin{array}{l}\text { C-North } \\
\text { Central }\end{array}$ & Chirinkotan & Chirinkotan 1 & $\begin{array}{l}\text { Erosion face, Profile 1, } 83 \\
\text { cmbs }\end{array}$ & $\mathrm{Ch}$ & $\begin{array}{l}\text { KBP } \\
2074 \\
\end{array}$ & $\begin{array}{l}\text { OS- } \\
67088\end{array}$ & $970 \pm 30$ & $934-796$ & $\mathrm{E}$ \\
\hline 11 & C-North & Chirinkotan & Chirinkotan 1 & Erosion face, Profile 1, 77 & $\mathrm{Ch}$ & KBP & OS- & $925 \pm 25$ & $918-788$ & $E$ \\
\hline
\end{tabular}




\begin{tabular}{|c|c|c|c|c|c|c|c|c|c|c|}
\hline & Central & & & $\mathrm{cmbs}$ & & 2073 & 67087 & & & \\
\hline 12 & $\begin{array}{l}\text { C-North } \\
\text { Central }\end{array}$ & Kharimkotan & Cape Ankuchi & $\begin{array}{l}\text { Fox hole exposure, } 60 \\
\text { cmbs. }\end{array}$ & $\mathrm{Ch}$ & $\begin{array}{l}\text { KBP } \\
3235\end{array}$ & $\begin{array}{l}\text { OS- } \\
80118\end{array}$ & $945 \pm 25$ & $924-795$ & C \\
\hline 12 & $\begin{array}{l}\text { C-North } \\
\text { Central }\end{array}$ & Kharimkotan & Cape Ankuchi & $\begin{array}{l}\text { Probe Survey, point 202, } \\
\text { house pit, } 40 \mathrm{cmbs}\end{array}$ & $\mathrm{Ch}$ & $\begin{array}{l}\text { KBP } \\
3210\end{array}$ & $\begin{array}{l}\text { OS- } \\
93692\end{array}$ & $240 \pm 30$ & $425-0$ & $E$ \\
\hline 12 & $\begin{array}{l}\text { C-North } \\
\text { Central }\end{array}$ & Kharimkotan & Cape Ankuchi & $\begin{array}{l}\text { Probe Survey, point 216, } \\
\text { house pit, } 40 \mathrm{cmbs}\end{array}$ & $\mathrm{Ch}$ & $\begin{array}{l}\text { KBP } \\
3224\end{array}$ & $\begin{array}{l}\text { OS- } \\
80119\end{array}$ & $85 \pm 25$ & $260-26$ & $E$ \\
\hline 12 & $\begin{array}{l}\text { C-North } \\
\text { Central }\end{array}$ & Kharimkotan & $\begin{array}{l}\text { Kharimkotan } \\
1\end{array}$ & $\begin{array}{l}\text { Erosion face: } 28-35 \mathrm{cmbs} \\
\text { (collected by M.E.Martin) }\end{array}$ & $\mathrm{Ch}$ & $\begin{array}{l}\text { KBP } \\
0973\end{array}$ & $\begin{array}{l}\text { OS- } \\
93672\end{array}$ & $1370 \pm 25$ & $\begin{array}{l}1328- \\
1269\end{array}$ & C \\
\hline 12 & $\begin{array}{l}\text { C-North } \\
\text { Central }\end{array}$ & Kharimkotan & $\begin{array}{l}\text { Lake } \\
\text { Lazurnoye }\end{array}$ & $\begin{array}{l}\text { Test Pit } 1 \text {, directly below } \\
\text { thin sand layer, } \sim 10 \mathrm{cmbs}\end{array}$ & $\mathrm{Ch}$ & $\begin{array}{l}\text { KBP } \\
3199\end{array}$ & $\begin{array}{l}\text { OS- } \\
98003\end{array}$ & $1090 \pm 25$ & $1058-937$ & $E$ \\
\hline 13 & $\begin{array}{l}\text { C-North } \\
\text { Central }\end{array}$ & Onekotan & Cape Gorely'y & Erosional face, $25-38 \mathrm{cmbs}$ & $\mathrm{Ch}$ & $\begin{array}{l}\text { KBP } \\
3294\end{array}$ & $\begin{array}{l}\text { OS- } \\
80121\end{array}$ & $3070 \pm 25$ & $\begin{array}{l}3358- \\
3214\end{array}$ & C \\
\hline 13 & $\begin{array}{l}\text { C-North } \\
\text { Central }\end{array}$ & Onekotan & Cape Gorely'y & $\begin{array}{l}\text { Probe Survey, point 8-VG- } \\
01-E \text {; house pit, } 70 \mathrm{cmbs}\end{array}$ & $\mathrm{Ch}$ & $\begin{array}{l}\text { KBP } \\
3305 a\end{array}$ & $\begin{array}{l}\text { OS- } \\
98005\end{array}$ & $2900 \pm 25$ & $\begin{array}{l}3142- \\
2957\end{array}$ & $E$ \\
\hline 13 & $\begin{array}{l}\text { C-North } \\
\text { Central }\end{array}$ & Onekotan & Cape Gorely'y & $\begin{array}{l}\text { Probe Survey, point 8-VG- } \\
01-\mathrm{B} \text {; house pit, } 22 \mathrm{cmbs}\end{array}$ & $\mathrm{Ch}$ & $\begin{array}{l}\text { KBP } \\
3303\end{array}$ & $\begin{array}{l}\text { OS- } \\
80120\end{array}$ & $910 \pm 25$ & $915-764$ & $E$ \\
\hline 13 & $\begin{array}{l}\text { C-North } \\
\text { Central }\end{array}$ & Onekotan & Cape Lisiy & $\begin{array}{l}\text { Probe Survey, point } 147 \text {; } \\
\text { house pit, } 90-100 \mathrm{cmbs}\end{array}$ & $\mathrm{Ch}$ & $\begin{array}{l}\text { KBP } \\
3285\end{array}$ & $\begin{array}{l}\text { OS- } \\
80148\end{array}$ & $1050 \pm 25$ & $1049-925$ & $E$ \\
\hline 13 & $\begin{array}{l}\text { C-North } \\
\text { Central }\end{array}$ & Onekotan & Cape Lisiy & $\begin{array}{l}\text { Probe Survey, point 148; } \\
\text { house pit, } 35 \mathrm{cmbs}\end{array}$ & $\mathrm{Ch}$ & $\begin{array}{l}\text { KBP } \\
3286\end{array}$ & $\begin{array}{l}\text { OS- } \\
98004\end{array}$ & $875 \pm 20$ & $900-731$ & $E$ \\
\hline 13 & $\begin{array}{l}\text { C-North } \\
\text { Central }\end{array}$ & Onekotan & Cape Lisiy & $\begin{array}{l}\text { Probe Survey, point 147; } \\
\text { house pit, } 45 \mathrm{cmbs}\end{array}$ & $\mathrm{Ch}$ & $\begin{array}{l}\text { KBP } \\
3284\end{array}$ & $\begin{array}{l}\text { OS- } \\
80123\end{array}$ & $150 \pm 30$ & $284-0$ & $E$ \\
\hline 13 & $\begin{array}{l}\text { C-North } \\
\text { Central }\end{array}$ & Onekotan & Cape Lisiy Bay & $\begin{array}{l}\text { Nakagawa Excavation, } \\
\text { Level } 2\end{array}$ & $\mathrm{Ch}$ & $\begin{array}{l}\text { KBP } \\
3280\end{array}$ & $\begin{array}{l}\text { OS- } \\
80122\end{array}$ & $1090 \pm 25$ & $1058-937$ & C \\
\hline 13 & $\begin{array}{l}\text { C-North } \\
\text { Central }\end{array}$ & Onekotan & Nemo Bay 2 & $\begin{array}{l}\text { Test Pit: cultural layer at } \\
147-152 \mathrm{cmbs} \text { (NGR } \\
\text { excavation) }\end{array}$ & $\mathrm{Ch}$ & $\begin{array}{l}\text { KBP } \\
3444\end{array}$ & $\begin{array}{l}\text { OS- } \\
93673\end{array}$ & $2460 \pm 25$ & $\begin{array}{l}2705- \\
2379\end{array}$ & C \\
\hline 13 & $\begin{array}{l}\text { C-North } \\
\text { Central }\end{array}$ & Onekotan & $\begin{array}{l}\text { Yagodnnyy } \\
\text { North }\end{array}$ & Test Pit $1,30-35 \mathrm{cmbs}$ & $\mathrm{Ch}$ & $\begin{array}{l}\text { KBP } \\
3254\end{array}$ & $\begin{array}{l}\text { OS- } \\
80153\end{array}$ & $1050 \pm 25$ & $1049-925$ & C \\
\hline 13 & $\begin{array}{l}\text { C-North } \\
\text { Central }\end{array}$ & Onekotan & $\begin{array}{l}\text { Yagodnnyy } \\
\text { North }\end{array}$ & Test Pit $1,17-18 \mathrm{cmbs}$ & $\mathrm{Ch}$ & $\begin{array}{l}\text { KBP } \\
3245\end{array}$ & $\begin{array}{l}\text { OS- } \\
80152\end{array}$ & $1000 \pm 30$ & $967-799$ & $E$ \\
\hline 13 & $\begin{array}{l}\text { C-North } \\
\text { Central }\end{array}$ & Onekotan & $\begin{array}{l}\text { Yagodnnyy } \\
\text { North }\end{array}$ & $\begin{array}{l}\text { Probe Survey, house pit \# } \\
9 ; 30-35 \mathrm{cmbs}\end{array}$ & $\mathrm{Ch}$ & $\begin{array}{l}\text { KBP } \\
3267\end{array}$ & $\begin{array}{l}\text { OS- } \\
80151\end{array}$ & $915 \pm 25$ & $919-767$ & $E$ \\
\hline
\end{tabular}




\begin{tabular}{|c|c|c|c|c|c|c|c|c|c|c|}
\hline 14 & $\begin{array}{l}\text { C-North } \\
\text { Central }\end{array}$ & Makanrushi & $\begin{array}{l}\text { Bukhta } \\
\text { Vostok }\end{array}$ & $\begin{array}{l}\text { Probe Survey, GPS \#174; } \\
\text { from old test pit, 20-30 } \\
\text { cmbs }\end{array}$ & $\mathrm{Ch}$ & $\begin{array}{l}\text { KBP } \\
3427\end{array}$ & \begin{tabular}{|l|} 
OS- \\
80028
\end{tabular} & $2250 \pm 25$ & $\begin{array}{l}2341- \\
2158\end{array}$ & C \\
\hline 14 & $\begin{array}{l}\text { C-North } \\
\text { Central }\end{array}$ & Makanrushi & $\begin{array}{l}\text { Bukhta } \\
\text { Vostok }\end{array}$ & $\begin{array}{l}\text { Probe Survey, GPS \#197; } 20 \\
\text { cmbs (see ID\#3435) }\end{array}$ & $\mathrm{Ch}$ & $\begin{array}{l}\text { KBP } \\
3436\end{array}$ & $\begin{array}{l}\text { OS- } \\
80029\end{array}$ & $1020 \pm 25$ & $977-835$ & $\mathrm{E}$ \\
\hline 14 & $\begin{array}{l}\text { C-North } \\
\text { Central }\end{array}$ & Makanrushi & $\begin{array}{l}\text { Bukhta } \\
\text { Vostok }\end{array}$ & $\begin{array}{l}\text { Probe Survey, GPS \#197; } \\
\text { house pit, } 30-35 \mathrm{cmbs}\end{array}$ & $\mathrm{Ch}$ & $\begin{array}{l}\text { KBP } \\
3437\end{array}$ & $\begin{array}{l}\text { OS- } \\
80030\end{array}$ & $1020 \pm 25$ & $977-835$ & $\mathrm{E}$ \\
\hline 14 & \begin{tabular}{|l|} 
C-North \\
Central \\
\end{tabular} & Makanrushi & $\begin{array}{l}\text { Bukhta } \\
\text { Vostok }\end{array}$ & $\begin{array}{l}\text { Probe Survey, GPS \#165; } \\
\text { house pit, 50-60 cmbs. }\end{array}$ & $\mathrm{Ch}$ & $\begin{array}{l}\text { KBP } \\
3418\end{array}$ & \begin{tabular}{|l|} 
OS- \\
80027 \\
\end{tabular} & $860 \pm 30$ & $901-695$ & $\mathrm{E}$ \\
\hline 14 & \begin{tabular}{|l|} 
C-North \\
Central
\end{tabular} & Makanrushi & Bukhta Zakat & $\begin{array}{l}\text { Probe Survey, GPS \#159, } \\
\text { house pit } 25 \mathrm{cmbs}\end{array}$ & $\mathrm{Ch}$ & $\begin{array}{l}\text { KBP } \\
3405\end{array}$ & \begin{tabular}{|l|} 
OS- \\
80112
\end{tabular} & $1090 \pm 25$ & $1058-937$ & C \\
\hline 14 & \begin{tabular}{|l|} 
C-North \\
Central \\
\end{tabular} & Makanrushi & Bukhta Zakat & $\begin{array}{l}\text { Test Pit 1, Level 5, } 124 \\
\text { cmbd in SE Quad }\end{array}$ & $\mathrm{Ch}$ & $\begin{array}{l}\text { KBP } \\
3347 a\end{array}$ & \begin{tabular}{|l|} 
OS- \\
95662 \\
\end{tabular} & $965 \pm 30$ & $932-796$ & $\mathrm{E}$ \\
\hline 14 & \begin{tabular}{|l|} 
C-North \\
Central \\
\end{tabular} & Makanrushi & Bukhta Zakat & Test Pit 1, Level 2, $77 \mathrm{cmbd}$ & $\mathrm{Ch}$ & $\begin{array}{l}\text { KBP } \\
3339\end{array}$ & \begin{tabular}{|l|} 
OS- \\
80115 \\
\end{tabular} & $910 \pm 25$ & $915-764$ & $\mathrm{E}$ \\
\hline 14 & \begin{tabular}{|l|} 
C-North \\
Central \\
\end{tabular} & Makanrushi & Bukhta Zakat & Test Pit 1, Level 4, $93 \mathrm{cmbd}$ & $\mathrm{Ch}$ & $\begin{array}{l}\text { KBP } \\
3342\end{array}$ & \begin{tabular}{|l|} 
OS- \\
80117 \\
\end{tabular} & $910 \pm 25$ & $915-764$ & $E$ \\
\hline 14 & \begin{tabular}{|l|} 
C-North \\
Central \\
\end{tabular} & Makanrushi & Bukhta Zakat & Test Pit 1, Level 3, $79 \mathrm{cmbd}$ & $\mathrm{Ch}$ & $\begin{array}{l}\text { KBP } \\
3341 \\
\end{array}$ & \begin{tabular}{|l|} 
OS- \\
80116 \\
\end{tabular} & $905 \pm 25$ & $913-746$ & $E$ \\
\hline 14 & \begin{tabular}{|l|} 
C-North \\
Central \\
\end{tabular} & Makanrushi & Bukhta Zakat & $\begin{array}{l}\text { Probe Survey, house pit B, } \\
25-28 \mathrm{cmbs}\end{array}$ & $\mathrm{Ch}$ & $\begin{array}{l}\text { KBP } \\
3372 \\
\end{array}$ & \begin{tabular}{|l|} 
OS- \\
80113 \\
\end{tabular} & $890 \pm 25$ & $907-735$ & $E$ \\
\hline 14 & \begin{tabular}{|l|} 
C-North \\
Central \\
\end{tabular} & Makanrushi & Bukhta Zakat & $\begin{array}{l}\text { Test Pit 1, } 25 \mathrm{cmbs} \text {; upper } \\
\text { part of sea urchin layer }\end{array}$ & $\mathrm{Ch}$ & $\begin{array}{l}\text { KBP } \\
3333\end{array}$ & \begin{tabular}{|l|} 
OS- \\
80114 \\
\end{tabular} & $885 \pm 25$ & $906-732$ & $E$ \\
\hline 14 & \begin{tabular}{|l|} 
C-North \\
Central \\
\end{tabular} & Makanrushi & Bukhta Zakat & Test Pit 1, Level 2 & $\mathrm{Ch}$ & $\begin{array}{l}\text { KBP } \\
3309\end{array}$ & \begin{tabular}{|l|} 
OS- \\
98008 \\
\end{tabular} & $830 \pm 20$ & $781-694$ & $E$ \\
\hline 15 & \begin{tabular}{|l|} 
D-North \\
Kurils \\
\end{tabular} & Paramushir & Okeanskoye & Test Pit 2, $70 \mathrm{cmbs}$ & $\mathrm{Ch}$ & $\begin{array}{l}\text { KBP } \\
0965 \\
\end{array}$ & \begin{tabular}{|l|} 
OS- \\
93610 \\
\end{tabular} & $3780 \pm 30$ & $\begin{array}{l}4245- \\
4009\end{array}$ & C \\
\hline 15 & $\begin{array}{l}\text { D-North } \\
\text { Kurils } \\
\end{array}$ & Paramushir & Okeanskoye & Test Pit 1 & $\mathrm{Ch}$ & $\begin{array}{l}\text { KBP } \\
0959\end{array}$ & \begin{tabular}{|l|} 
OS- \\
93609 \\
\end{tabular} & $1830 \pm 30$ & $\begin{array}{l}1864- \\
1639\end{array}$ & $E$ \\
\hline 15 & \begin{tabular}{|l|} 
D-North \\
Kurils \\
\end{tabular} & Paramushir & Savushkina 1 & Test Pit 2, Level 1 & $\mathrm{Ch}$ & $\begin{array}{l}\text { KBP } \\
0803\end{array}$ & \begin{tabular}{|l|} 
OS- \\
97896 \\
\end{tabular} & $2100 \pm 25$ & $\begin{array}{l}2137- \\
2000\end{array}$ & C \\
\hline 15 & \begin{tabular}{|l|} 
D-North \\
Kurils \\
\end{tabular} & Paramushir & Savushkina 1 & Test Pit 1, Level 2 & $\mathrm{Ch}$ & $\begin{array}{l}\text { KBP } \\
0805\end{array}$ & \begin{tabular}{|l|} 
OS- \\
67267 \\
\end{tabular} & $1910 \pm 30$ & $\begin{array}{l}1929- \\
1741\end{array}$ & $E$ \\
\hline 15 & D-North & Paramushir & Savushkina 1 & Test Pit 1, Level 1 & $\mathrm{Ch}$ & KBP & OS- & $1120 \pm 35$ & $1173-955$ & $E$ \\
\hline
\end{tabular}




\begin{tabular}{|c|c|c|c|c|c|c|c|c|c|c|}
\hline & Kurils & & & & & 0815 & 67268 & & & \\
\hline 15 & $\begin{array}{l}\text { D-North } \\
\text { Kurils }\end{array}$ & Paramushir & Savushkina 2 & Erosion face, Road Profile & $\mathrm{Ch}$ & $\begin{array}{l}\text { KBP } \\
0790\end{array}$ & $\begin{array}{l}\text { OS- } \\
93604\end{array}$ & $3750 \pm 25$ & $\begin{array}{l}4227- \\
3990\end{array}$ & C \\
\hline 15 & $\begin{array}{l}\text { D-North } \\
\text { Kurils }\end{array}$ & Paramushir & Savushkina 2 & Test Pit 1 , cultural level & $\mathrm{Ch}$ & $\begin{array}{l}\text { KBP } \\
0794\end{array}$ & $\begin{array}{l}\text { OS- } \\
93605\end{array}$ & $3740 \pm 25$ & $\begin{array}{l}4220- \\
3987\end{array}$ & $E$ \\
\hline 15 & $\begin{array}{l}\text { D-North } \\
\text { Kurils }\end{array}$ & Paramushir & Savushkina 2 & $\begin{array}{l}\text { Probe Survey: probe } \\
\text { sample in big house }\end{array}$ & $\mathrm{Ch}$ & $\begin{array}{l}\text { KBP } \\
0795\end{array}$ & $\begin{array}{l}\text { OS- } \\
93606\end{array}$ & $1740 \pm 25$ & $\begin{array}{l}1710- \\
1570\end{array}$ & $E$ \\
\hline 15 & $\begin{array}{l}\text { D-North } \\
\text { Kurils }\end{array}$ & Paramushir & $\begin{array}{l}\text { Tukharka } \\
\text { River } 1\end{array}$ & Test Pit 3, Level 1, $70 \mathrm{~cm}$ & $\mathrm{Ch}$ & $\begin{array}{l}\text { KBP } \\
0873\end{array}$ & $\begin{array}{l}\text { OS- } \\
59029\end{array}$ & $2560 \pm 30$ & $\begin{array}{l}2754- \\
2502\end{array}$ & C \\
\hline 15 & $\begin{array}{l}\text { D-North } \\
\text { Kurils }\end{array}$ & Paramushir & $\begin{array}{l}\text { Tukharka } \\
\text { River } 1\end{array}$ & Test Pit 1, $40 \mathrm{cmbs}$ & $\mathrm{Ch}$ & $\begin{array}{l}\text { KBP } \\
0872\end{array}$ & $\begin{array}{l}\text { OS- } \\
59028\end{array}$ & $60 \pm 30$ & $258-31$ & $E$ \\
\hline 15 & $\begin{array}{l}\text { D-North } \\
\text { Kurils }\end{array}$ & Paramushir & Zerkalnaya & $\begin{array}{l}\text { Erosion profile, above } \\
\text { sands }\end{array}$ & $\mathrm{Ch}$ & $\begin{array}{l}\text { IKIP } \\
0019\end{array}$ & $\begin{array}{l}\text { AA- } \\
40939\end{array}$ & $935 \pm 38$ & $929-766$ & A \\
\hline 15 & $\begin{array}{l}\text { D-North } \\
\text { Kurils }\end{array}$ & Paramushir & Zerkalnaya & $\begin{array}{l}\text { Erosion profile, } 36 \mathrm{cmbs} \text {, } \\
\text { just below lower sand lens }\end{array}$ & $\mathrm{Ch}$ & $\begin{array}{l}\text { IKIP } \\
0031\end{array}$ & $\begin{array}{l}\text { AA- } \\
40940\end{array}$ & $892 \pm 35$ & $911-733$ & A \\
\hline 15 & $\begin{array}{l}\text { D-North } \\
\text { Kurils }\end{array}$ & Paramushir & Zerkalnaya & Center of pit house test & $\mathrm{Ch}$ & $\begin{array}{l}\text { IKIP } \\
0029\end{array}$ & $\begin{array}{l}\text { AA- } \\
44257\end{array}$ & $206 \pm 35$ & $309-0$ & A \\
\hline 15 & $\begin{array}{l}\text { D-North } \\
\text { Kurils }\end{array}$ & Paramushir & Zerkalnaya & Center of pit house test & $\mathrm{Ch}$ & $\begin{array}{l}\text { IKIP } \\
0029\end{array}$ & $\begin{array}{l}\text { AA- } \\
41556\end{array}$ & $99 \pm 33$ & $269-13$ & A \\
\hline 16 & $\begin{array}{l}\text { D-North } \\
\text { Kurils }\end{array}$ & Shumshu & Baikova 1 & $\begin{array}{l}\text { Test Pit 4, Point B, } 120 \\
\text { cmbs }\end{array}$ & $\mathrm{Ch}$ & $\begin{array}{l}\text { KBP } \\
0854\end{array}$ & $\begin{array}{l}\text { OS- } \\
97898\end{array}$ & $5290 \pm 35$ & $\begin{array}{l}6184- \\
5948\end{array}$ & C \\
\hline 16 & $\begin{array}{l}\text { D-North } \\
\text { Kurils }\end{array}$ & Shumshu & Baikova 1 & Test Pit 3, $79 \mathrm{cmbs}$ & $\mathrm{Ch}$ & $\begin{array}{l}\text { KBP } \\
0963\end{array}$ & $\begin{array}{l}\text { OS- } \\
59038\end{array}$ & $2440 \pm 30$ & $\begin{array}{l}2700- \\
2357\end{array}$ & $E$ \\
\hline 16 & $\begin{array}{l}\text { D-North } \\
\text { Kurils }\end{array}$ & Shumshu & Baikova 1 & $\begin{array}{l}\text { Test Pit 1, level 4, 77-93 } \\
\text { cmbs }\end{array}$ & $\mathrm{Ch}$ & $\begin{array}{l}\text { KBP } \\
0949\end{array}$ & $\begin{array}{l}\text { OS- } \\
59037\end{array}$ & $2190 \pm 30$ & $\begin{array}{l}2310- \\
2127\end{array}$ & $E$ \\
\hline 16 & $\begin{array}{l}\text { D-North } \\
\text { Kurils }\end{array}$ & Shumshu & Baikova 1 & Test Pit 2, Level 6 & $\mathrm{Ch}$ & $\begin{array}{l}\text { KBP } \\
0929\end{array}$ & $\begin{array}{l}\text { OS- } \\
95638\end{array}$ & $2170 \pm 55$ & $\begin{array}{l}2325- \\
2008\end{array}$ & $E$ \\
\hline 16 & $\begin{array}{l}\text { D-North } \\
\text { Kurils }\end{array}$ & Shumshu & Baikova 1 & $\begin{array}{l}\text { Test Pit 1, Level 2, 47-57 } \\
\text { cmbs }\end{array}$ & $\mathrm{Ch}$ & $\begin{array}{l}\text { KBP } \\
0944\end{array}$ & $\begin{array}{l}\text { OS- } \\
59194\end{array}$ & $2110 \pm 25$ & $\begin{array}{l}2146- \\
2003\end{array}$ & $E$ \\
\hline 16 & $\begin{array}{l}\text { D-North } \\
\text { Kurils }\end{array}$ & Shumshu & Baikova 1 & $\begin{array}{l}\text { Test Pit 1, level 3, 57-77 } \\
\text { cmbs }\end{array}$ & $\mathrm{Ch}$ & $\begin{array}{l}\text { KBP } \\
0948\end{array}$ & $\begin{array}{l}\text { OS- } \\
59192\end{array}$ & $2010 \pm 35$ & $\begin{array}{l}2054- \\
1880\end{array}$ & D \\
\hline 16 & $\begin{array}{l}\text { D-North } \\
\text { Kurils }\end{array}$ & Shumshu & Baikova 1 & $\begin{array}{l}\text { Test Pit 1, Layer 1, 20-47 } \\
\text { cmbs }\end{array}$ & $\mathrm{Ch}$ & $\begin{array}{l}\text { KBP } \\
0941\end{array}$ & $\begin{array}{l}\text { OS- } \\
59193\end{array}$ & $1970 \pm 35$ & $\begin{array}{l}1995- \\
1830\end{array}$ & $E$ \\
\hline 16 & D-North & Shumshu & Baikova 1 & Test Pit 2, sod & $\mathrm{Ch}$ & KBP & OS- & $1370 \pm 25$ & 1328 & $\mathrm{E}$ \\
\hline
\end{tabular}




\begin{tabular}{|c|c|c|c|c|c|c|c|c|c|c|}
\hline & Kurils & & & & & 0906 & 95618 & & 1269 & \\
\hline 16 & $\begin{array}{l}\text { D-North } \\
\text { Kurils }\end{array}$ & Shumshu & Baikova 1 & Test pit 1, midden & $\mathrm{Ch}$ & $\begin{array}{l}\mathrm{IKIP} \\
0067\end{array}$ & $\begin{array}{l}\text { AA- } \\
40941\end{array}$ & $975 \pm 35$ & $953-795$ & $A$ \\
\hline 16 & $\begin{array}{l}\text { D-North } \\
\text { Kurils }\end{array}$ & Shumshu & Baikova 1 & Test Pit 2, Level 2 & $\mathrm{Ch}$ & $\begin{array}{l}\text { KBP } \\
0921\end{array}$ & $\begin{array}{l}\text { OS- } \\
95982\end{array}$ & $155 \pm 20$ & $284-1$ & $E$ \\
\hline 16 & $\begin{array}{l}\text { D-North } \\
\text { Kurils }\end{array}$ & Shumshu & Bol'shoy 1 & $\begin{array}{l}\text { Test Pit 3, Level 2, Midden } \\
\text { B }\end{array}$ & $\mathrm{Ch}$ & $\begin{array}{l}\text { KBP } \\
0828\end{array}$ & $\begin{array}{l}\text { OS- } \\
59198 \\
\end{array}$ & $3330 \pm 35$ & $\begin{array}{l}3678- \\
3466\end{array}$ & $\mathrm{C}$ \\
\hline 16 & $\begin{array}{l}\text { D-North } \\
\text { Kurils }\end{array}$ & Shumshu & Bol'shoy 1 & $\begin{array}{l}\text { Test Pit 2, Midden A, } \\
77 \mathrm{cmbs}\end{array}$ & $\mathrm{Ch}$ & $\begin{array}{l}\text { KBP } \\
0824\end{array}$ & \begin{tabular}{|l|} 
OS- \\
97897 \\
\end{tabular} & $2220 \pm 30$ & $\begin{array}{l}2324- \\
2152\end{array}$ & $E$ \\
\hline 16 & $\begin{array}{l}\text { D-North } \\
\text { Kurils }\end{array}$ & Shumshu & Bol'shoy 1 & $\begin{array}{l}\text { Test Pit } 1, \text { from inside } \\
\text { ceramic sherd }\end{array}$ & $\mathrm{Ch}$ & $\begin{array}{l}\text { KBP } \\
0833\end{array}$ & $\begin{array}{l}\text { OS- } \\
95616\end{array}$ & $2010 \pm 25$ & $\begin{array}{l}2035- \\
1892\end{array}$ & $E$ \\
\hline 16 & $\begin{array}{l}\text { D-North } \\
\text { Kurils }\end{array}$ & Shumshu & Bol'shoy 1 & $\begin{array}{l}\text { Test Pit 2, around sea lion } \\
\text { skull }\end{array}$ & $\mathrm{Ch}$ & $\begin{array}{l}\text { KBP } \\
0831\end{array}$ & $\begin{array}{l}\text { OS- } \\
59349\end{array}$ & $1180 \pm 30$ & $1221-999$ & $E$ \\
\hline 16 & $\begin{array}{l}\text { D-North } \\
\text { Kurils }\end{array}$ & Shumshu & Bol'shoy 2 & Test Pit $2 ; 24-40 \mathrm{cmbs}$ & $\mathrm{Ch}$ & $\begin{array}{l}\text { KBP } \\
0800\end{array}$ & $\begin{array}{l}\text { OS- } \\
93607 \\
\end{array}$ & $1760 \pm 25$ & $\begin{array}{l}1735- \\
1571\end{array}$ & $\mathrm{C}$ \\
\hline 16 & $\begin{array}{l}\text { D-North } \\
\text { Kurils }\end{array}$ & Shumshu & Bol'shoy 2 & Test Pit 2; 50-60 cmbs & $\mathrm{Ch}$ & $\begin{array}{l}\text { KBP } \\
0801\end{array}$ & $\begin{array}{l}\text { OS- } \\
93608\end{array}$ & $1620 \pm 40$ & $\begin{array}{l}1605- \\
1409\end{array}$ & $E$ \\
\hline 16 & $\begin{array}{l}\text { D-North } \\
\text { Kurils }\end{array}$ & Shumshu & Bol'shoy 2 & Test Pit 1, $209 \mathrm{cmbs}$ & $\mathrm{Ch}$ & $\begin{array}{l}\text { KBP } \\
0782\end{array}$ & $\begin{array}{l}\text { OS- } \\
93603\end{array}$ & $350 \pm 25$ & $492-315$ & $E$ \\
\hline 16 & $\begin{array}{l}\text { D-North } \\
\text { Kurils }\end{array}$ & Shumshu & Bol'shoy 2 & Test Pit 1, $280 \mathrm{cmbs}$ & Ch & $\begin{array}{l}\text { KBP } \\
0785\end{array}$ & $\begin{array}{l}\text { OS- } \\
93690\end{array}$ & $265 \pm 30$ & $434-0$ & $E$ \\
\hline
\end{tabular}

1. Site Name: Ekarma 1 site, originally identified in 2006, was later treated as a new site during the 2007 excavations and labelled "Ekarma 3." These are the same site and samples from both years are labeled Ekarma 1 here.

2. Context: Details on excavations and samples can be found in annual reports available through the Digital Archaeological

Repository (tDAR): Fitzhugh et al. 2007, Fitzhugh et al. 2009a, and 2009b. See References for access link.

3. Material: $\mathrm{BM}=$ marine bone (excluded from analysis); $\mathrm{Ch}=$ wood charcoal; $\mathrm{Ch}^{*}=$ wood charcoal recovered from Ainu $\mathrm{Creek}$ in 2007 post-disturbance, excluded from analysis; $W=$ unburned wood; $W B=$ wood bark.

4. Calibration: Oxcal 4.2, IntCal13, unless otherwise noted

5. Calibration: OxCal 4.2, Marine13

6. References: (A) Fitzhugh et al., 2002; (B) Fitzhugh, 2012; (C) Maclnnes et al., 2014; (D) Phillips and Speakman, 2009; (E) this paper 